\title{
11. Uzaktan eğitim sürecinde Türkçenin yabancı dil olarak öğretimi
}

\section{Kübra ŞENGÜL $\mathbf{L}^{1}$}

APA: Şengül, K. (2021). Uzaktan eğitim sürecinde Türkçenin yabancı dil olarak öğretimi. RumeliDE Dil ve Edebiyat Araştırmaları Dergisi, (24), 174-222. DOI: 10.29000/rumelide.995482.

$\ddot{\mathbf{O} z}$

$\mathrm{Bu}$ araştırmanın amacı, uzaktan eğitim sürecinde Türkçenin yabancı dil olarak öğretimini incelemektir. Nitel araştırma yöntemi ile hazırlanan çalışmada yapılandırılmış görüşme formları, elektronik posta yoluyla katılımcılara ulaştırılmıştır. Türkiye'de 21 üniversitenin Türkçe öğretim merkezinde yabancılara Türkçe öğreten 43 öğretim görevlisinin görüşleri, içerik analizi yöntemi ile Maxqda programında analiz edilmiştir. Elde edilen sonuçlara göre, öğretim görevlilerinin, COVID19'un bir sonucu olarak ortaya çıkan pandemi sürecinde, öğretmen-öğrenci, öğrenci-öğrenci etkileşiminin olumsuz yönde değiştiğini düşündükleri belirlenmiştir. Katılımcılar, etkileşimi artırmak için en çok sosyal medya kanallarını kullandıklarını ve akran danışmanlığı, dil partnerliği, konuşma kulübü uygulamalarına başvurduklarını belirtmişlerdir. Uzaktan yabancılara Türkçe öğretimi programında, bir ders saatini azaltma, etkinliklerin çeşidini değiştirme, dijital kitap kullanma, konulara ayrılan süreyi artırma gibi değişikliklere gidildiği belirlenmiştir. Türkçe öğrenme kurslarına kayıtlı olan kişi sayısının bir önceki yıla oranla düştüğü, devamsızlık yapan ve kayıt donduran öğrenci sayısının arttığı belirtilmiştir. Uzaktan yabancılara Türkçe öğretimi sürecinde, kamera ve ses aygıtlarını açmama, teknik sorunlar ve öz disiplindeki yetersizliklere bağlı olarak öğrencilerin derslere katılımlarının olumsuz yönde değiştiği; öğrencilerin en çok yazma ve konuşma becerilerine dönük etkinliklerde zorlandığı tespit edilmiştir. Öğreticilerin bu süreçte en çok temel dil seviyesindeki öğrencilerle ders işleyişinde zorlandığı; ölçme ve değerlendirmede en sık çoktan seçmeli, boşluk doldurmalı test maddelerini ve soru-cevap yöntemini kullandıkları sonucuna varılmıştır. Öğreticiler, yüz yüze eğitimdeki kadar verimli olamadıklarını, yoğun ve yıpratıcı bir çalışma süreci yaşadıklarını; buna karşın eksik yönlerini görme ve geliştirme imkânı bulduklarını belirtmişlerdir. Öğreticiler, bu süreçte öğrencilerin Türkçe öğrenme motivasyonlarının düştüğünü; öğrencilerin motivasyonunu artırmak için en çok hedef dilde film/video/şarkı dinlettiklerini belirtmişlerdir. Uzaktan yabancılara Türkçe öğretimi sürecinde öğrencilerin en sık, internet bağlantısı, teknik donanım ve dijital okuryazarlık yetersizliklerinden kaynaklanan sorunlar yaşadıkları; öğreticilerin ise kur atlama sınavlarında en sık etik sorunlar ve internet bağlantı sorunları yaşadıkları tespit edilmiştir. Son olarak öğreticiler, uzaktan yabancılara Türkçe öğretiminin en büyük avantajının bilgiye erişimin kolay ve mekân, para, zaman, mesafe açısından ekonomik olduğu yönünde görüş belirtmişlerdir.

Anahtar kelimeler: Türkçenin yabancı dil olarak öğretimi, uzaktan eğitim, COVID-19

Dr. Öğr. Üyesi, Nevşehir Hacı Bektaş Veli Üniversitesi, Eğitim Fakültesi, Türkçe ve Sosyal Bilimler Eğitimi Bölümü, Türkçe Eğitimi ABD (Nevşehir, Türkiye), kubraturkersengul@gmail.com, ORCID ID: 0000-0002-0307-9805 [Araştırma makalesi, Makale kayıt tarihi: 17.08.2021-kabul tarihi: 20.09.2021; DOI: 10.29000/rumelide.995482

Adres | Address

RumeliDE Dil ve Edebiyat Araştırmaları Dergisi Osmanağa Mahallesi, Mürver Çiçeği Sokak, No:14/8 Kadıköy - ISTANBUL / TÜRKIYE 34714 e-posta: editor@rumelide.com

RumeliDE Journal of Language and Literature Studies Osmanağa Mahallesi, Mürver Çiçeği Sokak, No:14/8

Kadıköy - ISTANBUL / TURKEY 34714 tel: +90 $5057958124,+902167730616$

e-mail: editor@rumelide.com, 


\title{
Teaching Turkish a foreign language during the distance education process
}

\begin{abstract}
The aim of this research is to study the teaching of Turkish as a foreign language during the distance education process. In the study, which has been done using a qualitative research method, structured interview forms were delivered to the participants via e-mail. The views of 43 lecturers who teach Turkish to foreigners in Turkish teaching centers of 21 universities in Turkey were analyzed using the content analysis method in the Maxqda program. According to the results, it was determined that the instructors thought that the teacher-student and student-student interactions have changed negatively during the pandemic that emerged as a result of COVID-19 virus. Participants stated that in order to increase interaction, they mostly use social media channels, and they resort to peer counseling, language partnership, and speaking club applications. It has been determined that some changes have been made in the program, such as shortening the classes, changing the type of activities, using digital books, and increasing the time allocated to the subjects. It was stated that the number of people enrolled in Turkish language courses has decreased compared to the previous year, and the number of students who were absent and or who suspended their registration has increased. During the process of teaching Turkish to foreigners through distance education, students' participation in the lessons has changed negatively because of not turning the camera and audio devices on, technical problems, and a lack of self-discipline. It has also been determined that students have the most difficulty in activities related to writing and speaking skills. It was concluded that during this process the teachers had the most difficulty with the students with a basic language level; for testing and evaluation they most frequently used multiple-choice, fill-in-the-blank test items, and the question-answer method. The trainers stated that they were not as productive as in in-person education and experienced an intense and tiring work phase. On the other hand, they stated that they had the opportunity to see and work on their incompetencies. The instructors stated that the motivation of the students to learn Turkish has decreased during this process and they mostly had the students listen to movies/videos/songs in the target language to increase student motivation. During the process of teaching Turkish as a foreign language during the distance education process, students most frequently experienced problems arising from issues with the internet connection, technical equipment, and ones related to digital literacy. On the other hand, it has been determined that the instructors have most frequently experienced ethical problems and internet connection problems during the tests given to the students to move on to the courses with a higher language level. Finally, the instructors stated that the biggest advantage of teaching Turkish to foreigners using distance education is that it makes it easy to access information and that it is economical in terms of space, money, time, and distance.
\end{abstract}

Keywords: Teaching Turkish as a foreign language, distance education, COVID-19

\section{Giriș}

İlk olarak 18. yüzyılda uygulamaya konan uzaktan eğitim (distance education), öğretmen ve öğrencinin içeriği aynı ortamda bulunmadan paylaştığı ve etkinlikleri çeşitli araçlar yoluyla haberleşerek sürdürdüğü bir eğitim şeklidir. Moore ve Kearsly (1996, s. 2) uzaktan eğitimin, özel bir ders planı yapma tekniğini, özel öğretim tekniklerini ve elektronik olan ya da olmayan sistemlerin kullanıldığı özel iletişim metotlarını içerdiğini belirtmektedir. Bu özel iletişim metotları, öğretmen ve öğrenciyi bir araya getirmek için eğitim medyası geliştiren bir örgüt tarafından yürütülmekte ve öğrenmenin uygun bir

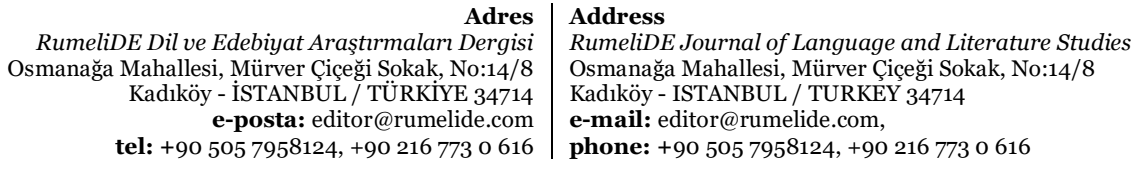


değerlendirmesini de sağlamaktadır (Verduin ve Clark, 1991, s. 19). Uzaktan eğitimin, bireysel veya kitlesel ihtiyaçlar durumunda kullananlara hayat boyu öğrenme ortamı sunması en dikkat çeken özelliğidir. Uşun (2006) da bu niteliklerin bir araya gelmesiyle uzaktan eğitimin öğrenenlere bireysellik, esneklik ve bağımsızlık olanağı tanıdığını belirtmiştir. Ĕgitimin uzaktaki öğrencilere ulaştırılmasında iletişimin mektup, radyo, televizyon gibi araçlarla sağlanmasına tek yönlü; etkileşimli radyolu ve televizyonlu konferans, internet tabanlı araçlarla sağlanmasına da çift yönlü iletişim modeli denmiştir (İşman, 1998).

Tarihî süreçte ilk uzaktan eğitim uygulamaları, öğretmen-öğrenci arasındaki etkileşimin posta servisi yoluyla sağlandığı basılı materyallere dayalı yazışmalardan oluşmaktadır. Dönemin teknolojik gelişmelerine bağlı olarak çeşitli araçlarla desteklenen (mektup, gazete, e-posta, video, çoklu ortam teknolojisi vs.) ve programın mekân ve zamandan bağımsız olarak düzenlendiği uzaktan eğitimde, uygulamalar çeşitli sebep/nedenlerle ortaya çımıştır. Bu etkenler, Tekdal'a (2020) göre zorunluluktan kaynaklı (doğal afetler, salgın hastalıklar, savaşlar), teknolojik gelişmelerden kaynaklı (iletişim teknolojilerindeki gelişmeler, internetin kullanımı ve internet teknolojilerindeki gelişmeler) ve beşeri kaynaklı (kişinin özgürlük durumundan kaynaklı, ekonomik yetersizlik kaynaklı, bedensel engellerden kaynaklı) olabilmektedir. Günümüzde ise eş zamanlı olarak ve çok hızlı bir şekilde çok sayıda insanı tehdit eden bulaşıcı bir hastalık olduğu için Dünya Sağlık Örgütü tarafından pandemik hastalık olarak ilan edilen COVID-19'un yayılma hızını düşürmek ve kamu sağlığını korumak amacıyla uzaktan eğitime geçilmiştir.

Uzaktan eğitimin, yüz yüze eğitime alternatif ya da yaşanılan olumsuz durumlara çare olarak kullanılmasında da teknoloji, her zaman merkezî bir rol oynamıştır. Bu açıdan bakıldığında teknolojik gelişmelerin dönemsel olarak uzaktan eğitime yön verdiği görülmektedir. Nipper (1989), Taylor (2001) ve Caladine (2008) tarafından oluşturulan kavramsal çerçeveler teknolojik gelişmelerin uzaktan eğitimi nasıl etkilediğini gözler önüne sermektedir.

Nipper (1989), uzaktan eğitimi o dönemin gelişmeleri ışığında üç nesilde sınıflandırmıştır. Bunlar; posta ile eğitim modeli, çoklu ortam modeli ve tele-öğrenme modelidir. İlk nesil uzaktan eğitim, öğretmenöğrenci arasındaki etkileşimi posta servisi yoluyla sağlanan basılı materyallere dayalı yazışma modeli; ikinci nesil, radyo ve televizyon gibi görsel işitsel teknolojik araçların kullanımına dayalı çoklu ortam modelidir. Çoklu ortam kavramı (Multimedya), en genel anlamıyla; düz metin yanında, sesin, durağan ve hareketli resimlerin, animasyonların, grafik, tablo gibi formların birden fazlasının etkili, verimli ve çekici bir bilgi sunumu için bilgisayar ortamında birlikte işe koşulmasıdır (Kuzu, 2017, s. 1). Çoklu ortam araçlarının dünya genelinde kullanımının yaygınlaşması, bu araçların uzaktan eğitim alanında etkili bir şekilde kullanımına yön vermiştir. Üçüncü nesil uzaktan eğitim modeli ise eş zamanlı (senkron) iletişim fırsatları sağlamak için telekomünikasyon teknolojilerinin uygulamalarına dayanan tele-öğrenme modeli olarak tanımlamıştır. Taylor (1995), uzaktan eğitimde ortaya çıkan dördüncü nesli, yüksek kaliteli CD ROM tabanlı etkileşimli multimedya (IMM) avantajlarını, öğretim-öğrenim kaynaklarını giderek daha kapsamlı hâle gelen internet erişimi ile birleştirdiği esnek öğrenme modeli olarak adlandırmıştır. Yeni teknolojilerin daha fazla kullanılmasıyla ortaya çıkan beşinci nesil uzaktan eğitim ise esasen internet ve Web’in özelliklerinden yararlanmayı amaçlayan dördüncü neslin bir türevi olarak tanımlanmıştır (Taylor, 2001).

Caladine (2008, s. 18) uzaktan eğitimde altıncı nesli, e-öğrenme modeli olarak adlandırmıştır. Bu son iki nesil arasındaki öğrenmedeki değişim, Web 1.o ile Web 2.0 arasındaki değişime dayanmaktadır. Ayrıca altıncı nesil uzaktan eğitimde, öğrenciler tarafından oluşturulan materyallerde fark edilir bir artış

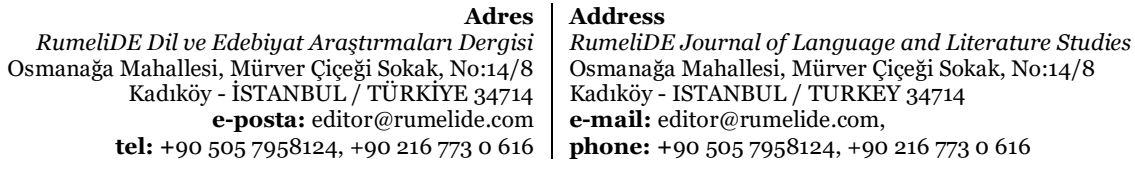


vardır. Öğrenciler bu süreçte, kendi oluşturdukları kaynaklarını veya öğrenme deneyimlerini öğretmenleri ve akranları ile Web 2.0 araçlarıyla paylaşabilirler.

Tarihî süreçte uzaktan eğitimin gelişimi basılı materyallerin gazete veya posta yoluyla öğretmen-öğrenci arasında paylaşımı ile başlayıp 70'li ve 8o'li yıllarda radyo, projektör, film ve televizyon gibi görsel-işitsel araçların kullanımı ile devam etmiştir. Bununla birlikte telekomünikasyon teknolojilerindeki gelişmeler, uzaktan eğitimde öğretmen ve öğrencilerin eş zamanlı bir şekilde iletişim kurmalarını sağlamıştır. 90’lı yllarda internet teknolojisinin gelişmeye başlaması ile uzaktan eğitimde esneyen hareket özgürlüğü ve imkânların artması ile öğretmen ve öğrenci arasındaki etkileşim daha yoğun bir nitelik kazanmıştır. Web 2.o teknolojilerinin ilerlemesi ve ortaya çıkan çevrim içi içerik üretme araçları sayesinde yüksek etkileşimli, tasarım açısından gelişmiş, zengin içeriğe sahip ve iş birliğine olanak veren araçların kullanıldığı bir noktaya ulaşılmıştır. Böylelikle uzaktan eğitimde öğrenci deneyimleri ve kaynakları öğrenme ortamlarına daha etkili bir şekilde yansımıştır. "İnternetin eğitimde kullanılması, ayrıca öğretme-öğrenme sürecinde; öğrenmeyi öğretme, yaşam boyu eğitim sağlama, bireysel farkları dikkate alma, öğrenmeye katılma, araştırma, keşfetme, modüler programlama ve öğrencinin öğrenme sürecini kendi öğrenme hızına göre programlama gibi imkânları sunmuştur” (Erturgut, 2008, s. 82).

Teknolojik imkânların artmasıyla uzaktan eğitim sürecinin daha esnek, işlevsel ve ekonomik bir şekilde uygulandığı görülmektedir. Ancak uzaktan eğitimde etkili bir öğretim sürecinin tek dayanağı da teknolojik gelişmeler değildir. Etkili bir öğretim için öğretmen yeterliklerinin, kullanılan ders kitaplarının, hazırlanan öğrenme içeriklerinin, öğrenen özelliklerinin uzaktan eğitim sürecine hazır hâle getirilmiş olması da önem arz etmektedir. Kaya'ya (2002, s. 12) göre, uzaktan eğitim, öğrenci danışmanlığı, öğrenci başarısının gözetilmesi ve korunması ve öğrenilen materyalin gösterilmesinde, her biri sorumluluk alan öğretmenlerin oluşturduğu bir ekip tarafindan yürütülen kendi kendine çalışma şeklinin sistematik olarak düzenlenmesidir.

Ders kitaplarının uzaktan eğitim sürecinde ekrandan takip edilebilmesi, çevrim içi etkinliklere uygun bir yapıda hazırlanması, öğrencilerin ders sonrasında da bağımsız ve kolay bir şekilde ders kaynağına Web uygulamasından ulaşabilmesi gerekmektedir. Bu bakımdan takip edilen ders kitaplarının uzaktan eğitim sürecine uygun bir yapıda olup olmadığı kontrol edilmeli ve varsa eksiklikler giderilmelidir. Alanyazını incelendiğinde Kaya, Kahraman ve Uysal'ın (2021), Yeni İstanbul Uluslararası Öğrenciler İçin Türkçe Öğretim Setinin uzaktan eğitim sürecinde kullanıma uygunluğunu inceledikleri çalışma dikkat çekmektedir. Çalışmada, ilgili öğretim setinin, WEB tabanlı uygulaması sayesinde etkileşim, öz izleme ve öz değerlendirme süreçlerinin etkin bir şekilde kullanıldığı belirtilmiştir.

Ders kaynaklarının donanımlı bir yapıda hazırlanmasına ek olarak öğretim sürecine rehberlik eden Türkçe okutmanlarının hangi tekniklerle Türkçenin uzaktan öğretilebileceği bilgisine ve deneyimine sahip olması gerekmektedir. Duman ve Yurdakul (2021), yabancılara Türkçe öğreten okutmanların uzaktan eğitim sürecine yönelik hazır bulunuşluklarını ve karşılaştıkları teknolojik alt yapı sorunlarını inceledikleri araştırmada, okutmanların \%60’ının salgından önce uzaktan eğitim yoluyla yabancılara Türkçe öğretmeye ilişkin herhangi bir deneyime sahip olmadıklarını, okutmanların kullandıkları öğretim yönetim sistemlerinde sorunlarla karşllaştıklarını, bununla birlikte katılımcıların \%83’ünün derslerde kendi materyallerini oluşturduklarını tespit etmişlerdir.

Eraslan ve Yücel (2021) ise Kazakistan ve Bosna-Hersek’te 12-18 yaş arasındaki öğrencilerin uzaktan eğitimle sürdürülen yabancı dil olarak Türkçe derslerine ilişkin görüşlerini incelemişlerdir. Araştırmada, öğrencilerin dersi takip etmede gereken teknik donanımlara sahip oldukları, ders

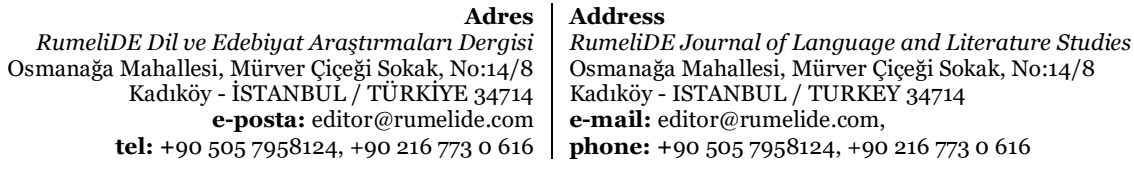


Teaching Turkish a foreign language during the distance education process / K. Şengül (pp. 174-222)

sırasında öğretmenlerine rahatça soru sorabildikleri, okuma, yazma, dinleme, konuşma ve alıştırma çalışmalarını ve 30 dakikalık ders sürelerini yeterli buldukları sonucuna varmışlardır. Bu çalışmada elde edilen sonuçların aksine Güngör, Çangal ve Demir (2020) yabancı dil olarak Türkçe öğrenen ve öğretenlerin, çalışmaların yüz yüze eğitim şeklinde olmasını tercih ettikleri, etkileşim, teknik alt yapı ve ödev kontrollerinde sorunlarla karşılaştıkları sonuçlarını elde etmişlerdir. Öte yandan, uzaktan eğitimin zaman ve mekân sınırlılığını ortadan kaldırması Türkçe okutmanlarının ve yabancı dil olarak Türkçe öğrenenlerin olumlu yönde görüş geliştirmesini sağlamıştır.

İskender (2021) ise uzaktan eğitim sürecinde A2 ve B2 seviyesinde iki sınıfta 2 saat süren gözlem sonuçlarını, öğretim elemanları ve öğrencilerle yaptığı görüşmelerle birlikte yorumlamıştır. Buna göre, uzaktan Türkçe öğretimi sürecinde ifade edici dil becerilerinin geliştirilmesinde zorluklarla karşılaşıldığı, gramer konularının öğretiminde verim alınamadığı, öğretim elemanlarının ve öğrencilerin çevrim içi sınıf ortamında uyum sorunları yaşadıkları tespit edilmiştir.

Alanyazını incelendiğinde çalışmaların nitel araştırma deseninde yürütüldüğü, çalışma verilerinin YÖK'e bağlı Kırgızistan -Türkiye Manas Üniversitesi'nden ve Ahmet Yesevi Üniversitesi'nden (Duman ve Yurdakul, 2021), Atatürk Üniversitesi Türkçe Öğretimi Uygulama ve Araştırma Merkezi’nden (İskender, 2021), Gazi Üniversitesi TÖMER'den (Güngör, Çangal ve Demir, 2020) Kazakistan ve BosnaHersek'ten (Eraslan ve Yücel, 2021) ulaşıldığı ve uzaktan yabancılar Türkçe öğretiminde bazı sorunlarla karşılaşıldığı tespit edilmiştir.

COVID-19'un bir sonucu olarak ortaya çıkan pandemi sürecinde, toplum sağlığını kontrol altına alabilmek için eğitim alanındaki çalışmaların uzaktan eğitim ile sürdürülmesi, Türkçenin yabancı dil olarak öğretiminde koşulların da değişmesine neden olmuştur. Bu değişiklik neticesinde öğretmenöğrenci, öğrenci-öğrenci etkileşim yoğunluğunun, öğrencilerin derslere katılımının, öğrenimi güçleşen dil becerilerinin, öğretimi güçleşen dil seviyelerinin, genel öğrenci saylarının, öğrenci motivasyonlarının, sınavlarda yaşanan sorunların, uygulanan ölçme ve değerlendirme tekniklerinin, öğretici öz değerlendirmelerinin, karşılaşılan sorunların ve avantajların uzaktan yabancılara Türkçe öğretiminde neler olduğunu derinlemesine bir şekilde ortaya koymak önem arz etmiştir. Bu nedenle araştırmada, uzaktan eğitimde Türkçenin yabancı dil olarak öğretim sürecini incelemek amaçlanmıştır.

\subsection{Araştırmanın amacı}

$\mathrm{Bu}$ araştırmanın amacı uzaktan eğitim sürecinde Türkçenin yabancı dil olarak öğretiminin incelenmesidir. Bu amaç doğrultusunda aşağıdaki sorulara yanıt aranmıştır.

1. COVID-19 Pandemi sürecinde Türkçe öğretim faaliyetlerinin uzaktan eğitim modeli ile sürdürülmesi öğrenci-öğretmen, öğrenci-öğrenci etkileşimini nasıl etkilemiştir?

2. Uzaktan yabancı dil olarak Türkçe öğretiminde öğrenci-öğretmen, öğrenci-öğrenci etkileşimini artırmak için uygulanan yöntem, teknik ya da etkinlikler nelerdir?

3. Uzaktan eğitim sürecinde yabancı dil olarak Türkçe öğretimi programında yapılan değişiklikler nelerdir?

4. Yabancı dil olarak Türkçe öğretimine devam öğrenci sayıları, uzaktan eğitimde nasıl etkilenmiştir?

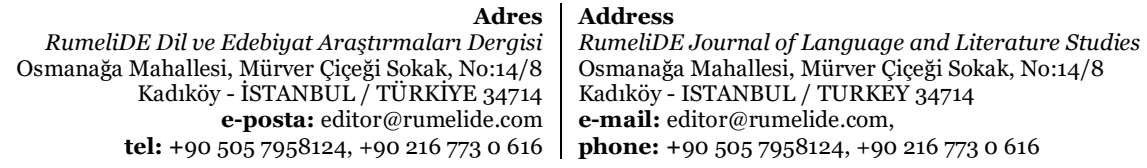

RumeliDE Dil ve Edebiyat Araştırmaları Dergisi tel: +90 $5057958124,+902167730616$ 
5. Yabancı dil olarak Türkçe öğrenenlerin yüz yüze eğitimdeki ders etkinliklerine katılımları ile uzaktan eğitimde canlı derslere katılımları arasındaki farklılıklar nelerdir?

6. Uzaktan Türkçe öğretiminde öğrencilerin anlamada/uygulamada zorlandı $\breve{g} ı$ dil becerileri nelerdir?

7. Uzaktan Türkçe öğretiminde okutmanların ders işleyişinde zorlandıkları dil seviyeleri nelerdir?

8. Uzaktan Türkçe öğrenme sürecinde öğrencilerin motivasyonlarında meydana gelen değişiklikler nelerdir?

9. Uzaktan Türkçe öğrenme sürecinde öğrencilerin motivasyonlarını artırmada kullanılan yöntem, teknik ya da uygulamalar nelerdir?

10. Uzaktan Türkçe öğrenme sürecinde öğrencilerin karşılaştıkları sorunlar nelerdir?

11. Uzaktan Türkçe öğretimi sürecinde kur atlama sınavlarında yaşanan sorunlar nelerdir?

12. Uzaktan Türkçe öğretiminde kullanılan ölçme ve değerlendirme teknikleri nelerdir?

13. Uzaktan eğitimin yabancı dil olarak Türkçe öğretimine sunduğu avantajlar nelerdir?

14. Türkçe okutmanlarının uzaktan Türkçe öğretimine ilişkin öz değerlendirmeleri nasıldır?

\section{Yöntem}

$\mathrm{Bu}$ bölümde çalışmanın araştırma modeli, çalışma grubu, verilerin toplanması ve analizi hakkında bilgiler verilmiştir.

\subsection{Araştırmanın modeli}

$\mathrm{Bu}$ çalışmada, uzaktan eğitim sürecinde Türkçenin yabancı dil olarak öğretimini derinlemesine incelemek için nitel araştırma yöntemi kullanılmıştır. "Nitel araştırma, kişilerin kanaatleri, tecrübeleri, algıları ve duyguları gibi subjektif verilere yönelerek olay ve olgular karşısında insanların neden böyle davrandığını, tutum ve davranışların arkasında yatan nedenlerin neler olduğunu ortaya koyma çabasındadır. Nitel araştırma sonucu elde edilen bulgular, çoğunlukla araştırma probleminin derinlemesine keşfedilmesini ve sosyal gerçekliğin farklı yönlerinin anlaşılmasını sağlar (Baltacı, 2019, s. 382)".

\section{2. Çalışma grubu}

Araştırmanın çalışma grubunu, Türkiye genelinde 21 üniversitenin TÖMER/DİLMER merkezlerinde ${ }^{2}$ görev yapan 43 öğretim görevlisi oluşturmaktadır. Çalışma grubuna ilişkin demografik bulgular Tablo 1'de gösterilmektedir.

Gazi Üniversitesi TÖMER, Ankara Üniversitesi TÖMER, Atatürk Üniversitesi TÖMER, Uludă̆ Üniversitesi TÖMER, Nevşehir Hacı Bektaş Veli Üniversitesi TÖMER, Tokat Gaziosmanpaşa Üniversitesi TÖMER, Sağlık Bilimleri Üniversitesi TÖMER, Akdeniz Üniversitesi TÖMER, Kocaeli Üniversitesi DÍLMER, Erciyes Üniversitesi ERSEM, Hatay Mustafa Kemal Üniversitesi TÖMER, Selçuk Üniversitesi TÖMER, Ylldırım Beyazit Üniversitesi TÖMER, Ahi Evran Üniversitesi TÖMER, Necmettin Erbakan Üniversitesi KONDİL, Bartın Yabancı Diller Yüksekokulu, Dumlupınar Üniversitesi

Adres Address

RumeliDE Dil ve Edebiyat Araştrmaları Dergisi $\quad$ RumeliDE Journal of Language and Literature Studies Osmană̆a Mahallesi, Mürver Ciçeği Sokak, No:14/8 $\quad$ Osmanağa Mahallesi, Mürver Çiçeği Sokak, No:14/8

Kadıköy - İSTANBUL / TÜRKIYE 34714 Kadıköy - ISTANBUL / TURKEY 34714

e-posta: editor@rumelide.com $\quad$ e-mail: editor@rumelide.com, tel: +90 $5057958124,+90216773$ o 616 phone: +90 505 7958124, +90 216773 o 616 


\begin{tabular}{|c|c|c|c|}
\hline & & $\mathrm{f}$ & $\%$ \\
\hline \multirow{3}{*}{ Cinsiyet } & Kadın & 18 & 42 \\
\hline & Erkek & 25 & 58 \\
\hline & Toplam & 43 & 100 \\
\hline \multirow{4}{*}{ Yaş } & $23-30$ & 10 & 23 \\
\hline & $31-40$ & 24 & 56 \\
\hline & $41-50$ & 9 & 21 \\
\hline & Toplam & 43 & 100 \\
\hline \multirow{4}{*}{ Eğitim Durumu } & Lisans & 6 & 14 \\
\hline & Yüksek Lisans & 20 & 46 \\
\hline & Doktora & 17 & 40 \\
\hline & Toplam & 43 & 100 \\
\hline \multirow{6}{*}{ Görev Süresi } & o-5 yll & 10 & 23 \\
\hline & 6-10 yll & 17 & 40 \\
\hline & 11-15 yıl & 7 & 16 \\
\hline & $16-20$ yll & 4 & 9 \\
\hline & 21-25 yll & 5 & 12 \\
\hline & Toplam & 43 & 100 \\
\hline
\end{tabular}

Tablo 1. İncelendiğinde 43 katılımcının 18’inin (\%42) kadın, 25’inin (\%58) erkek; 10’unun (\%23) 23-30 yaş, 24'ünün (\%56) 31-40 yaş, 9'unun (\%21) 41-50 yaş aralı̆̆ında olduğu, 6'sının (\%14) lisans, 20'sinin (\%46) yüksek lisans, 17'sinin (\%40) doktora mezunu olduğu, 10’unun (\%23) 0-5 yll, 17'sinin (\%40) 6-10 yll, 7’sinin (\%16) 11-15 yll, 4’ünün (\%9) 16-20 yll ve 5’inin (\%12) 21-25 yll arasında görev yaptı̆̆ görülmektedir.

\subsection{Veri toplama aracı}

Uzaktan eğitim sürecinde Türkçenin yabancı dil olarak öğretiminin incelenmesi için yapılandırılmış görüşme formu hazırlanmıştır. Bunun için öncelikle alan yazın çalışmaları derlenmiş ve uzaktan eğitim sürecinde Türkçenin yabancı dil olarak öğretimiyle ilgili yapılan uygulamaların, öğrenci ve öğretmenlerin karşılaştıkları olumlu ve olumsuz durumların, dil öğretiminin etkileşimsel boyutunun nasıl değiştiğinin, öğrenci motivasyonları ile öğretmen öz değerlendirmelerinin nasıl değerlendirildiğinin ortaya çıkarılması gerektiği düşünülmüştür. Bu doğrultuda araştırmacı tarafından oluşturulan yapılandırılmış görüşme formu, Türkçe Eğitimi alanında 2 uzman tarafından değerlendirilmiştir. Değerlendirmeler ve son düzenlemeden sonra yapılandırılmış görüşme formu aşă̆ıdaki 14 madde hâlinde kabul edilmiştir.

TÖMER, Osmaniye Korkut Ata Üniversitesi TÖMER, 19 Mayıs Üniversitesi TÖMER, Giresun Üniversitesi TÖMER, Trabzon Karadeniz Teknik Üniversitesi TÖMER

RumeliDE Dil ve Edebiyat Araşttrmaları Dergisi Osmanağa Mahallesi, Mürver Çiçeği Sokak, No:14/8 Kadıköy - İSTANBUL / TÜRKIYE 34714 e-posta: editor@rumelide.com

Address

RumeliDE Journal of Language and Literature Studies

Osmanağa Mahallesi, Mürver Çiçeği Sokak, No:14/8

Kadıköy - ISTANBUL / TURKEY 34714

tel: +90 $5057958124,+902167730616$

e-mail: editor@rumelide.com

phone: +90 505 7958124, +90 2167730616 


\subsubsection{Yapılandırılmış görüişme formu}

1- Covid-19 Pandemi sürecinde öğretim faaliyetlerinin uzaktan eğitim modeli ile sürdürülmesi yabancllara Türkçe öğretiminde öğrenci-öğretmen, öğrenci-öğrenci etkileşimini nasıl etkiledi?

2- Uzaktan eğitim ile sürdürülen yabancılara Türkçe öğretiminde öğrenci-öğretmen, öğrenci-öğrenci etkileşimini artırmak için uyguladı̆̆ınız yöntem, teknik ya da etkinlikler nelerdir?

3- Yüz yüze eğitimden farklı olarak uzaktan eğitim sürecinde öğretim programında hangi değişikliklere gitmek zorunda kaldınız?

4- Yüz yüze eğitimde öğretim sürecine devam eden öğrenci sayısı ile uzaktan eğitimde öğretim sürecine devam eden öğrenci sayıları arasında nasıl değişiklikler oldu?

5- Öğrencilerin yüz yüze eğitimdeki ders etkinliklerine katılımları ile uzaktan eğitimde canlı derslerdeki etkinliklere katılımları arasında nasıl bir fark gözlemlediniz?

6- Uzaktan eğitim ile öğrencilerin en çok hangi dil becerileri ile yapılan etkinliklerde zorlandığını düşünüyorsunuz?

7- Uzaktan eğitim sürecinde en çok hangi dil seviyesindeki öğrencilerle dersin işlenişinde zorluk yaşıorsunuz?

8- Uzaktan eğitim sürecinde öğrencilerin Türkçeyi öğrenme motivasyonları nasıl değişti?

9- Öğrencilerin Türkçeyi öğrenme motivasyonlarını artırmak için kullandığınız yöntem, teknik ya da uygulamalar nelerdir?

10- Uzaktan eğitim sürecinde öğrencilerin en çok hangi konularda sorun yaşadığını düşünüyorsunuz?

11- Öğrencilerin gelişimlerini takip etmek için uzaktan eğitimde sıklıkla kullandığınız ölçme ve değerlendirme teknikleri nelerdir?

12- Uzaktan eğitim sürecinde kur atlama sınavlarında yaşanan sorunlar nelerdir?

13- Yabancllara Türkçe öğretiminde uzaktan eğitimin sunduğu avantajlar nelerdir?

14- Yüz yüze eğitime nazaran uzaktan eğitimde kendinizi nasıl değerlendiriyorsunuz?

\subsection{Verilerin toplanması}

Araştırmanın verilerini elde etmek için öncelikle Türkçe öğretim merkezlerinde görev yapan okutmanlara e-posta yoluyla ulaşılmıştır. e-posta metninde çalışmaya gönüllü olarak katıldıklarını belirten bilgilendirilmiş onam belgesini onaylamaları istenmiştir. Araştırma için 45 öğretim görevlisi dönüş yapmış ancak 1 katılımcı araştırmaya gönüllü olarak katıldığını gösteren belgeyi onaylamadan cevapladığı için 1 katılımcı da soruların büyük bir çoğunluğunu yanıtlamadığı için 2 belge veri dosyasına dâhil edilmemiştir. Bununla birlikte araştırmaya, Türkçenin yabancı dil olarak öğretiminde aktif görev alan 43 öğretim görevlisi, değerli görüşlerini iletmişlerdir.

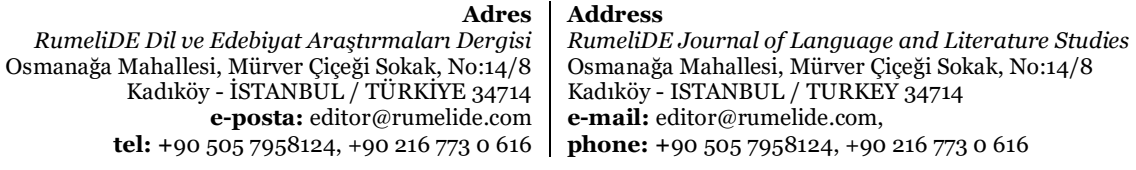




\subsection{Verilerin analizi}

Elde edilen verilerin çözümlenmesine içerik analizi yöntemi kullanılmıştır. “İçerik analizi, araştırmanın özüne ilişkin kalıpları, temaları, önyargıları ve anlamları belirlemek hedefiyle verilerin dikkatli, detaylı ve sistematik olarak incelenmesi; veri setinde sıklıkla tekrarlanan veya katılımcının yoğun bir şekilde vurgu yaptığı olay ve olgulardan kodlar çıkarılması; tespit edilen verilerin (kodlar) belirli kavramlar (kategoriler) ve temalar çerçevesinde bir araya getirilerek yorumlanmasıdır (Baltacı, 2019, s.377)".

Verilerin analizinde ilk olarak katılımcıların gizliliğini sağlamak için bir kod listesi hazırlanmıştır. Kodlar, katılımcıların kim olduklarını ve bireysel özelliklerini gizlemek için sayı, harf ya da sembollerin kullanılmasına dayanmaktadır. Bu araştırmada da katılımcılar K1, K2, K3 ... şeklinde kodlanmıştır. Katılımcı gizliliği sağlandıktan sonra kodlarla temsil edilen görüşler tek dosya şeklinde bir araya getirilmiş ve 42 sayfalık bir veri dosyası oluşturulmuştur.

Verilerin analizinde Maxqda programı kullanılmışıtır. Maxqda programında veri dosyasının işlenmesiyle belirli kavram ve temalara ulaşılmış ve elde edilen bulgular tablolar hâlinde betimlenmiştir.

\subsection{Etik kurallara uygunluk}

Araştırma sürecinde bilimsel ve etik kurallara uygun hareket edilmiştir. İlgili alan yazını titizlikle incelenmiş, yararlanılan kaynaklar metin içi ve metin dışı atıflarla belirtilmiştir. Veri toplama sürecine başlamadan önce Nevşehir Hacı Bektaş Veli Üniversitesi Etik Kurulu tarafından 12.01.2021 tarihinde araştırmanın gerçekleştirilmesine yönelik etik sakınca bulunmadığı kararı alınmıştır.

\section{Bulgular}

Bu bölümde araştırmanın alt amaçlarına uygun olarak elde edilen nitel bulgulara yer verilmiştir.

\subsection{Uzaktan yabancılara Türkçe öğretiminde öğrenci-öğretmen, öğrenci-öğrenci etkileşimine ilişkin bulgular}

Katılımcıların "COVID-19 Pandemi sürecinde Türkçe öğretim faaliyetlerinin uzaktan eğitim modeli ile sürdürülmesi öğrenci-öğretmen, öğrenci-öğrenci etkileşimini nasıl etkilemiştir?” sorusuna verdikleri yanıtlardan elde edilen bulgular Tablo 2'de gösterilmektedir.

\begin{tabular}{|c|c|c|c|c|c|}
\hline \multicolumn{4}{|c|}{ Öğretmen-Öğrenci Etkileşimi } & \multicolumn{2}{|c|}{ Öğrenci-Öğrenci Etkileşimi } \\
\hline \multicolumn{2}{|c|}{ Olumsuz } & \multicolumn{2}{|c|}{ Olumlu } & \multicolumn{2}{|c|}{ Olumsuz } \\
\hline $\mathrm{f}$ & $\%$ & $\mathrm{f}$ & $\%$ & $\mathrm{f}$ & $\%$ \\
\hline 41 & 91,11 & 4 & 8,88 & 30 & 100 \\
\hline
\end{tabular}

Tablo 2 incelendiğinde öğretmen-öğrenci etkileşiminin olumsuz yönde etkilendiğini belirten 41 (\%91,11) görüş yer almıştır. Öğretmen-öğrenci etkileşiminin olumsuz yönde etkilendiğini belirten örnek görüşler şöyledir:

K12: Uzaktan eğitimin öğretmen-öğrenci etkileşimini bir anlamda olumsuz etkilediğini düşünüyorum. Yeni kaydolan öğrencilerimizi hiç görmemek, birebir tanımamak beni üzüyor. Yolda yan yana

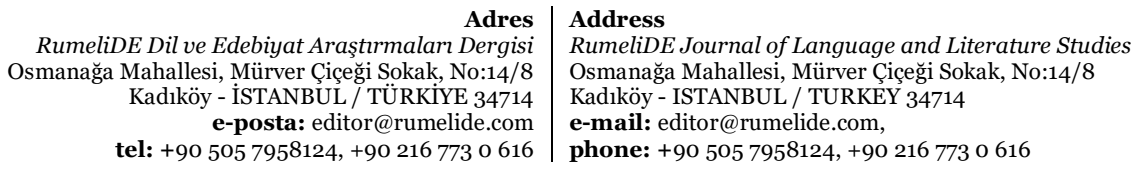


yürüsek kendisinin öğrencim olduğunu belki bilemeyeceğim. Zira bazıları kamerayı açmak istemiyor. Bunun dışında uzaktan eğitim yüz yüze eğitim kadar etkili ve samimi değil. Bir şekilde ayak uyduruyoruz.

K18: Duygusal olarak uzaklaştık, uzaklaştılar. Yüz yüze eğitim sürecinde birlikte yaptı̆̆ımız ve bu bağlamda bağlarımızı güçlendiren aktiviteleri yapamaz olduk. Mesajlar, duygularımızı iletmek için yeterli olmuyor. Çevrimiçi etkinlikler düzenledik ancak yüz yüze eğitimin verdiği konforu da verimliliği de sağlamıyor.

Tablo 2'ye göre, öğretmen-öğrenci etkileşiminin olumlu olarak etkilendiğini belirten $4(\% 8,88)$ görüş belirtilmiştir. Bulgulara göre, ders dışında gelişen mesajlaşma ve konuşmaya yönelik paylaşımlar öğretmenler ile öğrenciler arasındaki etkileşimi olumlu yönde etkilemiştir. Öğretmen-öğrenci etkileşiminin olumlu yönde etkilendiğini belirten örnek görüşler şöyledir:

K2: Öncelikle bu sürecin hiçbirimizin hazırlıkh olduğu bir ana denk gelmediğini bildirmekte fayda var. Biz eğiticiler öğrencilerimizle zaten hep bir etkileşim içerisinde olmaya özen gösterdik. Bu süreç başladı̆̆ında da hep onların yanında durduk. Onları tüm gelişmelerden haberdar ettik.

K5: Ancak buna zıt olarak öğrenci-öğretmen etkileşimini oldukça iyi yönde etkilediğini düşünüyorum. Yüz yüze eğitimde öğrenciler öğretmenle telefon yoluyla iletişim kurmuyorlardı. Şu an öğrenciöğretmen arasında telefon yoluyla hızh ve aktif bir etkileşim bulunmakta.

Tablo 2 incelendiğinde uzaktan yabancllara Türkçe öğretiminde öğrenci-öğrenci etkileşiminin olumsuz yönde etkilendiğini bildiren 30 (\%100) görüş bildirilmiştir. Öğrenci-öğrenci etkileşiminin olumsuz yönde etkilendiğini belirten örnek görüşler şöyledir:

K2: Lakin bu süreçte öğrencilerimizin birbirleri ile sımıf içinde kurdukları etkileşim ve iletişim ister istemez kesintiye uğradı. Onlar aynı simıftalar ama birbirlerine yabancı bir birey gibiler.

K5: Öğrenci-öğrenci ilişkilerini olumsuz yönde etkilediğini düşünüyorum. Çünkü öğrencilerin ortak bir paylaşım ortamı bulunmadiğından sınıf içi akran iletişiminin geliştiğini düşünmüyorum.

Elde edilen bulgular, uzaktan Türkçe öğretim sürecinde öğretmenler ile öğrenciler arasında etkileşimin azaldığını, öğreticilerin bu durumu öğrencilerin ders sırasında kamera ve ses aygıtlarını açmamalarına, etkileşim sürecinde önemli olan göz teması ve beden hareketlerini kullanamamalarına bağlamışlardır. Özellikle yeni kayıt olan öğrenciler ile öğretmenlerin birbirleriyle tam olarak etkileşime geçemedikleri belirtilmiştir. Uzaktan yabancılara Türkçe öğretiminde öğrenci-öğrenci etkileşimine ilişkin olumlu bir görüşün belirtilmemiş olması dil öğrenme sürecinde öğrencilerin birbirinden öğrenemediklerini ve hedef dili kullanamadıklarını ortaya çımıştır. Öğrenci-öğrenci etkileşimine ilişkin katılımcı görüşlerinin tamamının olumsuz yönde belirtilmesi ise uzaktan yabancılara Türkçe öğretiminde birlikte çalışma stratejilerinden mahrum kalındığını göstermektedir.

\subsection{Uzaktan yabancılara Türkçe öğretiminde öğrenci-öğretmen, öğrenci-öğrenci etkileşimini artırmak için kullanılan yöntem, teknik ve etkinliklere ilişkin bulgular}

Katılımcıların "Uzaktan eğitim ile sürdürülen yabancılara Türkçe öğretiminde öğrenci-öğretmen, öğrenci-öğrenci etkileşimini artırmak için uyguladığınız yöntem, teknik ya da etkinlikler nelerdir?” sorusuna verdikleri yanttlardan elde edilen bulgular Tablo 3 ’te gösterilmektedir.

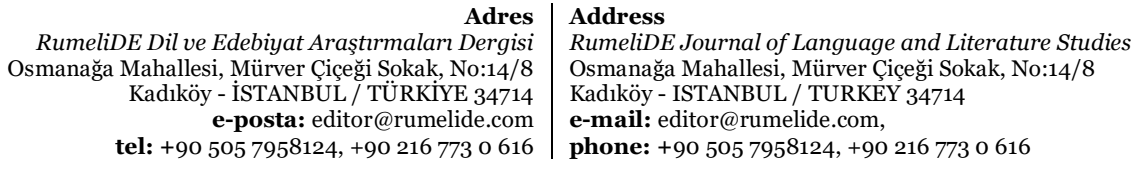


184 / RumeliDE Journal of Language and Literature Studies 2021.24 (September)

Teaching Turkish a foreign language during the distance education process / K. Şengül (pp. 174-222)

\begin{tabular}{lll}
\hline Tablo 3. Etkileşimi Artırmak İçin Kullanılan Yöntem, Teknik ve Etkinlikler & & \\
\hline Kodlar & $\mathrm{f}$ & $\%$ \\
\hline Sosyal Medya Grupları & 15 & 28,30 \\
\hline Akran Danışmanlı̆̆ı & 6 & 11,32 \\
\hline Dil Partnerliği & 6 & 11,32 \\
\hline Çevrim İçi Etkinlikler & 6 & 11,32 \\
\hline Konuşma Kulübü & 5 & 9,43 \\
\hline Danışmanlı Dil Öğretim Yöntemi & 3 & 5,66 \\
\hline Bilişsel Yöntem & 2 & 3,77 \\
\hline Dijital Oyunlar & 2 & 3,77 \\
\hline Telefon Görüşmesi & 2 & 3,77 \\
\hline Doğal Yöntem & 1 & 1,88 \\
\hline Eklektik Yöntem & 1 & 1,88 \\
\hline İsitsel-Görsel Yöntem & 1 & 1,88 \\
\hline Telkin Yöntemi & 1 & 1,88 \\
\hline Tutor Destekli Öğretim & 1 & 1,88 \\
\hline Tüm Fiziksel Tepki Yöntemi & 1 & 1,88 \\
\hline TOPLAM & 53 & 100,00 \\
\hline
\end{tabular}

Tablo 3 incelendiğinde katılımcıların etkileşimi artırmak için sosyal medya ( $\mathrm{f}=15, \% 28,30$ ) kanallarını kullandıkları; akran danışmanlığ $(\mathrm{f}=6, \% 11,32)$, dil partnerliği $(\mathrm{f}=6, \% 11,32)$, çevrim içi etkinlikler $(\mathrm{f}=6$, $\% 11,32)$ ve konuşma kulüpleri $(\mathrm{f}=5, \% 9,43)$ gibi uygulamalardan faydalandıkları görülmektedir. Bunun dışında danışmanlı dil öğretim yöntemi ( $\mathrm{f}=3, \% 5,66)$, bilişsel yöntem ( $\mathrm{f}=2, \% 3,77)$, dijital oyunlar $(\mathrm{f}=2$, \%3,77), telefon görüşmesi ( $\mathrm{f}=2, \% 3,77)$, doğal yöntem ( $\mathrm{f}=1, \% 1,88)$, eklektik yöntem ( $\mathrm{f}=1, \% 1,88)$, işitselgörsel yöntem ( $\mathrm{f}=1, \% 1,88)$, telkin yöntemi $(\mathrm{f}=1, \% 1,88)$, tutor destekli öğretim ( $\mathrm{f}=1, \% 1,88)$ ve tüm fiziksel tepki yöntemi $(\mathrm{f}=1, \% 1,88)$ etkileşimi artırmada kullanılan diğer yöntemler olarak bildirilmiştir.

Bulgulara göre, katılımcıların etkileşimi artırmak için en çok sosyal medya kanallarına ( $\mathrm{f}=\mathbf{1 5}, \% \mathbf{2 8 , 3 0})$ başvurdukları görülmektedir. Böylelikle ders sırasında kısıtlı zaman içinde oluşturulamayan etkileşim yolları telafi edilmeye çalışılmıştır.

K3: Bu süreçte öğrencilerimizin bizimle ve diğer öğrencileriyle etkileşimli olmalar için sosyal medyada gruplar oluşturarak buluşmaları sağlandı.

K21: Çeşitli sosyal medya araçlarını dil öğretimine entegre ederek öğrenciler ile olan diyaloglarımızı ders dışı zamanlara da yaymak zorunda kaldık.

Tablo 3 incelendiğinde katılımcıların etkileşimi artırmak için akran danışmanlığından $(f=6, \% 11,32)$ faydalandıkları görülmektedir.

K26: Bu noktada akran danışmalığını çok gördük, destekledik. Öğrencilerimizin hepsi elbette aymı hazır bulunuluşlukta değildi. Ama yan yanaydılar birbirlerini desteklediler. Anlamadıkları noktaları birbirlerine anlattılar. Hatta eski öğrencilerimden şöyle teklifler aldım. Yeni öğrencilerimle konuşmak, onları motive etmek istediklerini söylediler.

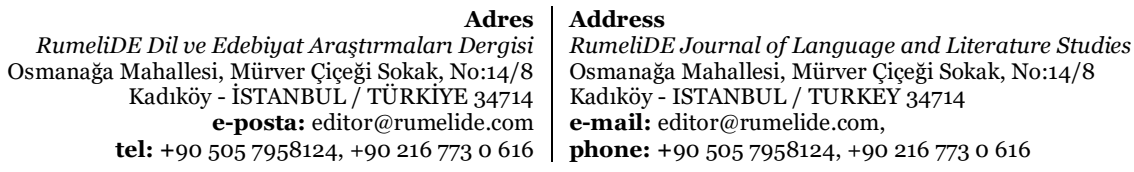


K43: Bunun dışında bu süreci yaşamış eski başarılı öğrencilerimle iletişime geçmelerine olanak sağladım. Çünkü yabancı, kendi yaşlarma yakm ve bu süreci geçirmiş bireylerle daha iyi iletişime geçip çekindikleri ya da akıllarına takılan sorular hakkında fikir alışverişi yapmalarma ortam hazırladım.

Tablo 3 incelendiğinde uzaktan yabancılara Türkçe öğretiminde etkileşimi artırmak için kullanılan diğer bir yöntem ise dil partnerliğidir $(\mathrm{f}=6, \% 11,32)$. Bu sayede öğrencilere, dil öğrenme sürecinde ihtiyaç duydukları sosyalleşme ve dili kültürel bağlam içinde öğrenme firsatları sunulmuştur.

K3o: Daha çok dil partnerliğini uygulamaktayız.

K41: Aynı dili konuşanlardan birbirlerine yardımcı olmalarını sağlamaktayız.

Tablo 3'e göre uzaktan yabancllara Türkçe öğretiminde etkileşimi artırmak için ders dışında çevrim içi etkinliklerinin $(\mathrm{f}=6, \% 11,32)$ düzenlendiği bildirilmiştir. Çevrim içi etkinliklerde öğrencilerin ve öğretmenlerin eş zamanlı bir şekilde katıldıkları oturumlarda çeşitli konularda gerçekleştirilen samimi konuşmalar ile öğrencilerin hem öğretmenleriyle hem de birbirleriyle etkileşimini artırmak amaçlanmıştır.

K1: Öğrencilerin bazıları Türkiye’deyken bu karantina dönemine girdikleri için aileden uzak olmak ve sürecin belirsizliği onlar daha çok etkilemiş ve kendilerini yalnız hissetmelerine neden olmuştu. Bu sebeple özel günlere denk gelen tüm tarihlerde ders dışı online etkinlikler yapmaya çalıştım. Ramazan ayında online iftar, online sinema saati, online bayramlaşma gibi...

K2: Ders dışında pandemiden önce alş̧kanlıklarımızı arar olmuştuk, çevrimiçi toplantılar yaparak sohbetler yapmaya devam etmiştik.

Tablo 3'e göre uzaktan yabancılara Türkçe öğretiminde etkileşimi artırmak için konuşma kulüplerinin $(\mathrm{f}=5, \% 9,43)$ düzenlendiği bildirilmiştir. Konuşma kulüplerinde öğrenciler, ders algısından uzaklaşıp daha samimi bir ortamda arkadaşlarıyla iletişim kurma imkânı yakalamıştır.

K4: Akşamları mesajlaşma uygulamalarında konuşma partisi adında bir saate aşkın konuşma etkinlikleri düzenliyoruz. Her öğrenci başka bir öğrenciye soru sormak zorunda. Bu şekilde diyalog genişliyor.

K32: Haftalık ders programının dışına çıkarak fazladan sohbet dersleri oluşturup formel olmayan, samimi bir havada öğrencilerle iletişimi geliştirme, belli bir seviyede tutma girişiminde bulunduk.

\subsection{Uzaktan yabancılara Türkçe öğretimi programında yapılan değişikliklere ilişkin bulgular}

Katılımcıların "Yüz yüze eğitimden farklı olarak uzaktan eğitim sürecinde öğretim programında hangi değişikliklere gitmek zorunda kaldınız?” sorusuna verdikleri yanıtlardan elde edilen bulgular Tablo 4’te gösterilmektedir.

\begin{tabular}{|c|c|c|}
\hline Kodlar & $\mathrm{f}$ & $\%$ \\
\hline Teknolojik materyal kullanımının artması & 22 & 27,50 \\
\hline $\begin{array}{r}\text { Adres } \\
\text { RumeliDE Dil ve Edebiyat Araştrrmalar Dergisi } \\
\text { Osmanağa Mahallesi, Mürver Ciçeği Sokak, No:14/8 } \\
\text { Kadıköy - İSTANBUL / TÜRKiYE } 34714 \\
\text { e-posta: editor@rumelide.com } \\
\text { tel: +90 505 7958124, +90 } 216773 \text { o } 616\end{array}$ & \multicolumn{2}{|c|}{$\begin{array}{l}\text { Address } \\
\text { RumeliDE Journal of Language and Literature Studies } \\
\text { Osmanağa Mahallesi, Mürver Ciçeği Sokak, No:14/8 } \\
\text { Kadıköy - ISTANBUL / TURKEY } 34714 \\
\text { e-mail: editor@rumelide.com, } \\
\text { phone: +90 505 7958124, +90 } 216773 \text { o } 616\end{array}$} \\
\hline
\end{tabular}




\begin{tabular}{lll}
\hline Ders saatinin azalması & 20 & 25,00 \\
\hline Etkinliklerin değiştirilmesi & 13 & 16,25 \\
\hline Dijital kitapların kullanılması & 8 & 10,00 \\
\hline Konulara ayrılan sürenin artması & 5 & 6,25 \\
\hline Ders saatlerinde değişiklik & 5 & 6,25 \\
\hline Teneffüs süresinin değişmesi & 3 & 3,75 \\
\hline Ev ödevlerinde değişiklikler & 1 & 1,25 \\
\hline Öğretim içeriğinde ve kazanımlarda değişiklik & 1 & 1,25 \\
\hline Kur saatlerinin düzenlenmesi & 1 & 1,25 \\
\hline Ders saatlerinde esnek yaklaşım & 1 & 1,25 \\
\hline TOPLAM & 80 & 100,00 \\
\hline
\end{tabular}

Tablo 4 incelendiğinde katılımcılar, uzaktan yabancılara Türkçe öğretimi programında gidilen değişiklikleri; teknolojik materyal kullanımının artması $(\mathrm{f}=\mathbf{2 2}, \% 27,50)$, ders saatinin azalması $(\mathrm{f}=\mathbf{2 0}$, \%25,00), etkinliklerin değiştirilmesi $(\mathrm{f}=13, \% 16,25)$, dijital kitapların kullanılması $(\mathrm{f}=8, \% 10,25)$, konulara ayrılan sürenin artması $(\mathrm{f}=5, \% 6,25)$, ders saatlerinde $(\mathrm{f}=5, \% 6,25)$, teneffüs süresinin değişmesi $(\mathrm{f}=3, \% 3,75)$ ev ödevlerinde değişiklikler $(\mathrm{f}=1, \% 1,25)$, öğretim içeriğinde ve kazanımlarda değişiklik ( $\mathrm{f}=1, \% 1,25)$, kur saatlerinin düzenlenmesi $(\mathrm{f}=1, \% 1,25)$, ders saatlerinde esnek yaklaşım ( $\mathrm{f}=1$, $\% 1,25)$ olarak belirtmişlerdir.

Tablo 4’te elde edilen bulgulara göre uzaktan yabancılara Türkçe öğretiminin beraberinde getirdiği en dikkate değer değişiklik teknoloji tabanlı materyallerin kullanımının artmasıdır ( $f=22, \% 27,50)$.

K5: Yüz yüze eğitimde de oldukça teknolojik materyalleri kullanmama rağmen uzaktan eğitim sürecinde bu materyalleri kullanmak zorunlu hâle geldi.

K26: Yüz yüze eğitimde cüzdanımız ayakkabımız duvarm rengi ya da duvardaki saat bile materyal olabilirken uzaktan eğitimde bu yerini ayn şekilde fotoğraflara, videolara dönüştürdü. Bu süreç içinde Web 2.o araçlarılla haşır neşir olduk.

Tablo 4’te elde edilen bulgulara göre uzaktan yabancılara Türkçe öğretimi sürecinde görülen diğer önemli bir değişiklik ders saatlerinin azaltılmasıdır $(\mathrm{f}=20, \% 25,00)$. Ders saatlerindeki azalmanın nedeni olarak öğretim yönetim sistemleri, öğrencilerin kullandıkları araçlar ve öğrencilerin dikkat süreleri gösterilmiştir.

K7: Öncelikle ders saatlerini azalttık. Öğrencilerin bilgisayar veya telefon derse bağlandıklarmı göz önüne aldiğımızda dikkat süresi kısalacağından böyle bir karar alındı.

K14: Uzaktan öğretimde öğrencinin dikkati çok daha çabuk dağıldiğından ders süresi 40 dakikadan 30 dakikaya indirilmiştir.

Tablo 4 incelendiğinde uzaktan eğitim sürecinde diğer bir değişiklik ders etkinliklerinde $(\mathrm{f}=13, \% 16,25)$ görülmüştür. Bu değişikliklerin uzaktan eğitimde öğrencilerin etkinliklere katılım sağlamamasına, dijital içeriklere ve kısıtlı zaman dilimine bağlı olarak ortaya çıktığı belirtilmiştir.

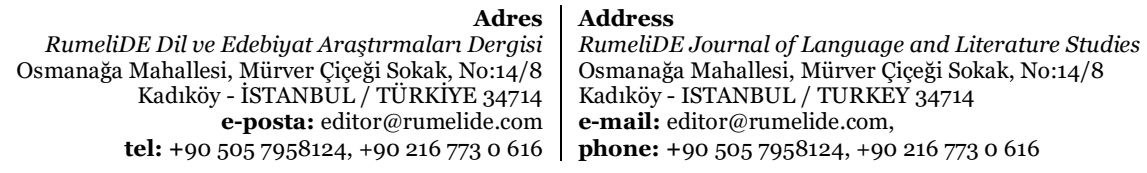


K28: Yüz yüze eğitimde öğrencinin daha fazla fiziksel hareket etmesini sağhyordum ancak dïitalde bu daha az mümkün oldu.

K3o: Etkinliklerde değişime gittik. Örneğin; video ve kısa filmleri daha etkili kullanmaya başladık.

Tablo 4'e göre uzaktan yabancılara Türkçe öğretiminde kitap kullanımının dijital kitap şekline göre değiştiği $(\mathrm{f}=8, \% 10,25)$ belirtilmiştir.

K15: Materyal olarak Yunus Emre Enstitüsü’nün eğitim setlerini kullaniyoruz ve setlerin "Z Kitap" olarak kullanımda olması ve bütün becerileri geliştirmeye yönelik olması işimi kolaylaştırmaktadır.

K39: Dijital kitap kullanımına geçildi. İstanbul Üniversitesinin Z kitabı bunun için çok uygun.

Tablo 4'te elde edilen bulgulara göre uzaktan yabancılara Türkçe öğretimi sürecinde konulara ayrılan zamanın arttı̆̆ı $(\mathrm{f}=5, \% 6,25)$ belirtilmiştir. $\mathrm{Bu}$ durum süreçte öğrencilerin zorlanmasından kaynaklanmıştır.

K4: Yazma etkinliğinde dikte çalş̧masın çevrimiçi yaparken internetten dolayı sorunlar yaşanıyor. Bu nedenle dikteyi üç dört tekrarla tamamlayabiliyoruz.

K36: Bir haftada işlenecek konu, üç haftaya kadar uzadı diyebilirim.

Tablo 4'e göre uzaktan yabancılara Türkçe öğretimi sürecinde ders saatlerinde değişiklik ( $f=5, \% 6,25)$ yapıldı̆̆ görülmektedir.

K1: Ders saatleri değişmek zorunda kaldı.

K22: Yüz yüze eğitimde her gün yapılan 6 saatlik ders yerini 3,5 saate brrakmıştır.

Tablo 4'e göre uzaktan eğitim sürecinde ders aralarına ayrılan sürede değişiklik ( $\mathrm{f}=3, \% 3,75)$ görülmüştür.

K12: Ders aralarma 15 dakikalk molalar koyduk.

K29: Daha fazla teneffüs vermeye çalş̧ıyorum. Öğrencinin dikkati çabuk dağıldiğı için daha fazla dinlendirmeye çalş̧ıyorum. Teneffüslerde sıcak bir şeyler içmelerini istiyorum.

\subsection{Uzaktan yabancılara Türkçe öğretimine devam eden öğrenci sayılarına ilişkin bulgular}

Katılımcıların "Yabancı dil olarak Türkçe öğretimine devam eden öğrenci sayıları, uzaktan eğitimde nasıl etkilenmiştir?” sorusuna verdikleri yanttlardan elde edilen bulgular Tablo 5 ’te gösterilmektedir.

\begin{tabular}{|c|c|c|}
\hline \multicolumn{3}{|l|}{ Tablo 5. Öğrencilerin Devam Durumları } \\
\hline Kodlar & $\mathrm{f}$ & $\%$ \\
\hline Öğrenci sayısı düştü & 22 & 42,3 \\
\hline Devamsız/kayıt donduran öğrenci sayısı arttı & 13 & 25 \\
\hline Öğrenci sayısı arttı & 11 & 21,1 \\
\hline $\begin{array}{r}\text { Adres } \\
\text { RumeliDE Dil ve Edebiyat Araştrmalart Dergisi } \\
\text { Osmanağa Mahallesi, Mürver Ciçeği Sokak, No:14/8 } \\
\text { Kadıköy - İSTANBUL / TÜRKIYYE } 34714 \\
\text { e-posta: editor@rumelide.com } \\
\text { tel: }+90 \text { 505 7958124, +90 } 2167730616\end{array}$ & $\begin{array}{l}\text { Address } \\
\text { RumeliDE Journal of Language and Literatur } \\
\text { Osmanağa Mahallesi, Mürver Ciçeği Sokak, No } \\
\text { Kadıköy - ISTANBUL / TURKEY } 34714 \\
\text { e-mail: editor@rumelide.com, } \\
\text { phone: +90 505 7958124, +90 } 216773 \text { o } 616\end{array}$ & \\
\hline
\end{tabular}




\begin{tabular}{lll}
\hline Öğrenci sayısında değişiklik görülmedi & 6 & 11,5 \\
\hline Toplam & 52 & 100 \\
\hline
\end{tabular}

Tablo 5 incelendiğinde katılımcıların 22'si $(\% 42,3)$ uzaktan yabancılara Türkçe öğretiminde öğrenen sayılarının düştüğünü, 13’ü (\%25) devamsız/kayıt donduran öğrencilerin arttığını, 11’i (\%21,1) öğrenci sayılarının arttığını ve 6'sı $(\% 11,5)$ öğrenci sayılarında değişiklik olmadığını belirtmiştir.

Elde edilen bulgulara göre $22(\% 42,3)$ katılımcı, uzaktan yabancılara Türkçe öğretiminde öğrenen sayılarının düştüğünü belirtmiştir.

K5: Yüz yüze eğitim sürecinden uzaktan eğitime ilk geçildiği tarihlerde, öğrenci sayısında düşüşler yaşand. Öğrenciler "internetten de öğrenirim” diye düşünmüş olacaklar ki, uzaktan eğitime geçildiğinde öğrenci sayıları düştü.

K15: Öğrencilerimizin bir bölümü Türkiye Bursları öğrencisi olmakla birlikte büyük kısmı da kendi imkanları ile Türkiye'ye gelip burada eğitim almak isteyen öğrencilerinden oluşmaktadır. Şu an uçuş kısıtlamaları ya da ülkelerin uyguladıklar salgin politikaları birbirinden farkh olmakla birlikte Türkiye'ye gelemeyen öğrencilerin kendi ülkelerinden kurslara katılmaların sağhyoruz. Türkiye genelinde bu sene kayıt ya da başvuru yapan uluslararası öğrenci sayısında salgın sebebi ile ciddi düşüs görülmektedir.

K38: Yüz yüze eğitime devam eden öğrencilerin sayısı ile uzaktan eğitime katılım bağlamında çeşitli değişkenler devreye girdiği gözlenmiştir. Bunlarm başında YTB öğrencilerin, ücretli öğrencilere göre internete olan erişim zorluğu ve ülkelerinin sosyoekonomik durumlarmdan kaynakh derse katılım konusunda çeşitli sıkıntılar yaşandiğı gözlemlenmiştir. Bunun yanı sıra bu tarz bir eğitim modeli ile ilk kez karşılaşan öğrencilerin duruma adapte olmaları da zaman almıştır. Bu süreçte kayıt dondurma yoluna giden veya eğitimi bırakmak zorunda olan öğrencilerle de karşılaşılmıştır.

Tablo 5 incelendiğinde, 13 (\%25) katılımcı uzaktan yabancılara Türkçe öğretiminde devamsız/kayıt donduran öğrenci sayılarının arttığını belirtmiştir.

K16: Ülkesindeki internet problemi nedeniyle verimli bir şekilde süreci devam ettiremeyeceğine inanan birkaç ögrrenci kaydını dondurdu.

K26: Kimi yüz yüze eğitim başlayınca devam edeceğim diyerek ülkelerine döndü. Kimi derslere kayıth olmasına rağmen çeşitli problemler çerçevesinde derslere katılmadı.

Tablo 5 incelendiğinde $11(\% 21,1)$ katılımcı uzaktan yabancılara Türkçe öğretiminde öğrenenlerin sayısının arttığını bildirmiştir. Uzaktan eğitimin şehir dışında ve yurt dışında yaşayanlar için avantaj oluşturduğunu özellikle ücretli öğrenci sayılarında artış gözlemlendiği belirtilmiştir.

K2: Sonrasinda bu krizi firsata çevirmek isteyen öğrenciler de oldu.

K4: Öğrenci sayımızı daha fazla artt. Ayrıca yurt dışında yaşayıp ülkemize gelmeden Türkçe öğrenen öğrenci sayımız hayli fazla. Uzaktan eğitim bizlere farkh imkânlar sağladı.

K37: Ücretli öğrenci sayısında bir artış oldu.

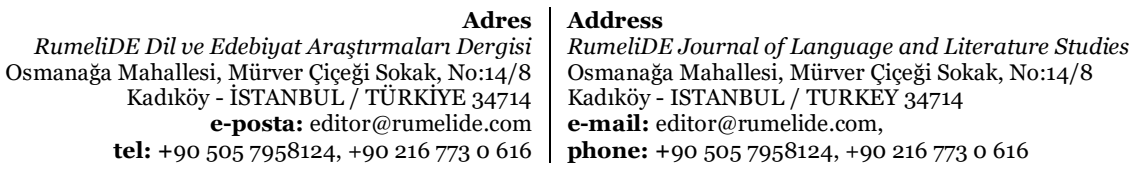


Tablo 5 incelendiğinde 6 katılımcı uzaktan yabancılara Türkçe öğretiminde öğrenenlerin sayısında değişiklik görülmediğini belirtmiştir.

K1o: Öğrenci sayısında bir değişiklik olmadı. 24-25 kişilik sınıflarda eğitim veriyoruz.

K23: Devam eden öğrenci sayısında çok fazla değişiklik yaşanmadı. Şehir dışındaki öğrencilerin uzaktan eğitimi değerlendirdikleri görülmektedir. Sonuç olarak toplam öğrenci sayısına bakıldığında fazla bir değişiklik görülmemektedir.

Elde edilen bulgular, uzaktan yabancılara Türkçe öğretiminde öğrenen sayılarının düştüğünü bunun nedenini de öğrencilerin zorlanmalarına, kendi çabalarıyla öğrenebileceklerine inanmalarına ve internet sorunu yaşamalarına bağlı olarak geliştiğini göstermiştir. Uzaktan yabancılara Türkçe öğretiminde devamsı//kayıt donduran öğrenci sayılarının arttığını belirten katılımcılar bu durumun nedeni olarak öğrencilerin pandemi sürecinin bitmesiyle yüz yüze eğitim şeklini alma isteklerini ve öğrencilerin yaşadıkları internet sorunlarını göstermişlerdir. Uzaktan yabancılara Türkçe öğretiminde öğrenenlerin sayısının arttığını bildiren katılımcılar ise uzaktan eğitimin şehir dışında ve yurt dışında yaşayanlar için avantaj oluşturduğunu özellikle ücretli öğrenci sayılarında artış gözlemlendiğini belirtmişlerdir.

\subsection{Uzaktan yabancılara Türkçe öğretiminde öğrencilerin ders etkinliklerine katılımlarına ilişkin bulgular}

Katılımcıların "Öğrencilerin yüz yüze eğitimdeki ders etkinliklerine katılımları ile uzaktan eğitimde canlı derslerdeki etkinliklere katılımları arasında nasıl bir fark gözlemlediniz?” sorusuna ilişkin verdikleri yanıtlardan elde edilen bulgular Tablo 6'da gösterilmektedir.

\begin{tabular}{lll}
\hline Tablo 6. Öğrencilerin Ders Etkinliklerine Katılım Durumları & & \\
\hline Kodlar & $\mathrm{f}$ & $\%$ \\
\hline Derse katılımları olumsuz & 38 & 77,55 \\
\hline Derse katılımları olumlu & 7 & 14,29 \\
\hline Fark yok & 4 & 8,16 \\
\hline TOPLAM & 49 & 100,00 \\
\hline
\end{tabular}

Tablo 6 incelendiğinde katılımcıların 38’i $(\% 77,55)$ uzaktan yabancılara Türkçe öğretiminde öğrencilerin derse katılımlarının olumsuz yönde değiştiğini, 7'si $(\% 14,29)$ olumlu yönde değiştiğini, 4’ü ise belirgin bir fark gözlemlemediklerini belirtmiştir.

Elde edilen bulgulara göre katılımcıların büyük bir çoğunluğu $(38, \% 77,55)$, uzaktan yabancılara Türkçe öğretiminde öğrencilerin derse katılımlarının olumsuz yönde değiştiğini belirtmiştir.

K7: Kimi teknik sorunlar sebebiyle derse giremezken kimi öğrenciler de bunu bir firsat görerek kamera ve mikrofonlarm kapatarak dersi etkin takip etmemişlerdir. Öz sorumlulukları yeterli düzeyde olmayan öğrenciler pandemiyi bahane ederek derse katılmamış ya da etkin bir şekilde dinlememişlerdir.

K28: Devam problemi olmasa da verimlilik problemi doğuyor. Nitekim mikrofonum bozuk, internetim yavaş gibi bahanelerle açılmayan kameralarda öğrencilerin varhı̆̆ meçhulleşebiliyor.

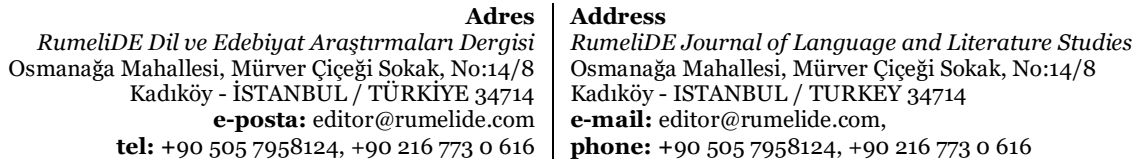


Tablo 6 incelendiğinde katılımcıların 7’si $(\% 14,29)$ uzaktan yabancılara Türkçe öğretiminde öğrencilerin derse katılımlarının olumlu yönde değiştiğini belirtmiştir.

K18: Görüntü açma zorunluluğu bulunan sinıflarda katılımda düşüş olmadı ve aktif olarak katıldılar.

K26: Ancak şöyle ilginç bir durumla da karşılaştım. Bazı milletlerden gelen öğrencilerimiz özellikle kız öğrencilerimiz sını içinde çok çekingen davranışlar sergiliyorlardı. Ancak uzaktan eğitimle sanal sinıflarda biraz daha aktif olmaya başladılar.

Tablo 6 incelendiğinde katılımcıların 4’ü $(\% 8,16)$ uzaktan yabancılara Türkçe öğretiminde öğrencilerin derse katılımlarının yüz yüze eğitime göre herhangi bir fark göstermediğini belirtmiştir. Bunun nedenini ise öğrencilerin odaklanmalarına, aktif olmalarına ve uzaktan eğitim döneminden önce öğretmen ve öğrencilerin birbirlerini tanımalarına bağlı olduğunu belirtmişlerdir.

K17: Çok fark yok. Aktif öğrenci yine aktif. Pasif ise yine pasif.

K34: Yüz yüze eğitimde epey zaman beraber olduğumuzdan öğretmen-öğrenci kendini tanımış idi. Bu sebeple uzaktan eğitimde de derse ve etkinliklere katılımlar arasında bir fark oluşmad.

Elde edilen bulgular, uzaktan yabancılara Türkçe öğretiminde öğrencilerin derse katılımlarının olumsuz yönde değiştĭgini göstermiş̧tir. Bunun nedenleri arasında öğrencilerin kamera ve ses aygıtlarını açmamaları, teknik sorunlar yaşamaları ve öz disiplin sorunları gösterilmiştir. Uzaktan yabancılara Türkçe öğretiminde öğrencilerin derse katılımlarının olumlu yönde değiştiğini belirten katılımcılar ise bu durumun kamera açma zorunluluğuna dayandığını, kız öğrencilerin kendilerini daha rahat hissetmelerine bağlı olarak ortaya çıtığı belirtmiştir. Uzaktan yabancılara Türkçe öğretiminde öğrencilerin derse katılımlarının yüz yüze eğitime göre herhangi bir fark oluşturmadığını belirten katılımcılar bunun nedeninin ise öğrencilerin odaklanmalarına, aktif olmalarına ve uzaktan eğitim döneminden önce öğretmen ve öğrencilerin birbirlerini tanımalarına bağlı olduğunu belirtmişlerdir.

\subsection{Uzaktan yabancılara Türkçe öğretiminde öğrencilerin en çok zorlandıkları dil becerileri etkinliklerine ilişkin bulgular}

Katılımcıların "Uzaktan eğitim ile öğrencilerin en çok hangi dil becerileri ile yapılan etkinliklerde zorlandığını düşünüyorsunuz?” sorusuna ilişkin verdikleri yanıtlardan elde edilen bulgular Tablo 7’de gösterilmektedir.

\begin{tabular}{lll}
\hline \multicolumn{2}{l}{ Tablo 7. Öğrencilerin En Çok Zorlandıkları Dil Becerileri } \\
\hline Kodlar & $\mathrm{f}$ & $\%$ \\
\hline Yazma & 26 & 44,07 \\
\hline Konuşma & 26 & 44,07 \\
\hline Dinleme & 7 & 11,86 \\
\hline TOPLAM & 59 & 100,00 \\
\hline
\end{tabular}

Tablo 7 incelendiğinde öğrencilerin en çok yazma $(n=26, \%=44,07)$ ve konuşma $(n=26, \%=44,07)$ becerilerine dönük etkinliklerde zorlandıkları belirtilmiştir. Katılımcıların 7'si $(\% 11,86)$ ise öğrencilerin dinleme becerilerine dönük etkinliklerde zorlandıklarını belirtmiştir.

\footnotetext{
Adres $\mid$ Address

RumeliDE Dil ve Edebiyat Araştırmaları Dergisi $\quad$ RumeliDE Journal of Language and Literature Studies Osmanağa Mahallesi, Mürver Çiçeği Sokkak, No:14/8 $\quad$ Osmanağa Mahallesi, Mürver Çiçeği Sokak, No:14/8 Kadıköy - ÍSTANBUL / TÜRKIYE 34714 Kadıköy - ISTANBUL / TURKEY 34714 e-posta: editor@rumelide.com e-mail: editor@rumelide.com, tel: +90 505 7958124, +90 2167730616 phone: +90 505 7958124, +90 2167730616
} 
Öğrencilerin en çok yazma becerisine dönük etkinliklerde zorlandığını belirten katılımcı $(\mathrm{n}=26$, $\%=44,07$ ) görüşlerinden bazıları şöyledir.

K14: Kesinlikle en çok yazma becerisinde zorlanıyorlar, zaten yüz yüze eğitimde de yazma becerisi zorlanılan bir beceri uzaktan eğitimde yazma etkinliklerine yer verilememesi daha da zorlaşttrmıştır.

K19: Uzaktan eğitim ile öğrencilerin en çok yazma ile yapılan etkinliklerde zorlandiğını düşünmekteyim. Yazma çalşmalarmin Word ortaminda e-posta üzerinden gönderilmesi istenildiğinde öğrencilerin bilgisayar kullanma becerilerinin yetersizliği başta olmak üzere yazma becerilerinin verimli olmadığı görülmektedir.

Öğrencilerin en çok konuşma becerisine dönük etkinliklerde zorlandığını belirten katılımcı $(n=26$, $\%=44,07)$ görüşlerinden bazıları şöyledir.

K1: Elbette ki konuşma yetisinde büyük bir gerileme oldu. Pratik yapacakları doğal bir ortam ya da hedef dili duyacakları, kullanacakları kişilerle temasları şu an en az seviyede.

K8: Uygulamaya dayah olan konuşma ve yazma becerilerinde zorlandıklarmı düşünüyorum. Konuşmada isteksizler. Yazmada da anllk göremediğiniz için anında dönüt biraz sorun oluyor. Konuşmada telaffuz, yazmada bazı harflerin yazımında sorun yaşanıyor.

Öğrencilerin en çok dinleme becerisine dönük etkinliklerde zorlandığını belirten katılımcı $(n=7, \% 11,86)$ görüşlerinden bazıları şöyledir.

K42: Sosyalleşme az olduğu için konuşma ve dinleme becerilerinde zorlanıyorlar.

K43: Dinleme olarak düşünüyorum. Çünkü öğrencilere ideal bir dinleme ortamı oluşturulamıyor. Gözlem altında standartlara uygun dinleme yapmak oldukça zor. Her ne kadar bu sorunlara çözümler arayıp denesem de yüz yüze eğitimdeki gibi bir dinleme ortamı sağlandığını düşünmüyorum.

Elde edilen bulgular, uzaktan yabancılara Türkçe öğretiminde öğrencilerin en çok yazma ( $\mathrm{n}=\mathbf{2 6}$, $\%=44,07)$ ve konuşma $(n=26, \%=44,07)$ becerilerine dönük etkinliklerde zorlandıklarını göstermiştir. $\mathrm{Bu}$ süreçte öğrencilerin yazma motivasyonlarının düştüğü, bir yazma etkinliğini devam ettirmede zorlandıkları, yazma çalışmalarının Word dosyasına geçirmekte, e-posta yoluyla öğretmenlerine gönderme gibi işlerde ve klavye kullanmada zorlandıkları belirtilmiştir. Pratik yapacak doğal bir ortamın bulunmaması, etkileşimin azalması, konuşmaya isteksiz davranılması, internet bağlantısında ve seste meydana gelen kopukluklar nedeniyle öğrencilerin konuşma becerilerine dönük etkinliklerde zorlandıkları tespit edilmiştir.

\subsection{Uzaktan yabancılara Türkçe öğretiminde dersin işlenişinde zorlanılan dil seviyesine ilişkin bulgular}

Katılımcıların "Uzaktan eğitim sürecinde en çok hangi dil seviyesindeki öğrencilerle dersin işlenişinde zorluk yaşıyorsunuz?” sorusuna ilişkin verdikleri yanıtlardan elde edilen bulgular Tablo 8'de gösterilmektedir.

Tablo 8. Ders İşlenişinde Zorlanılan Dil Seviyeleri

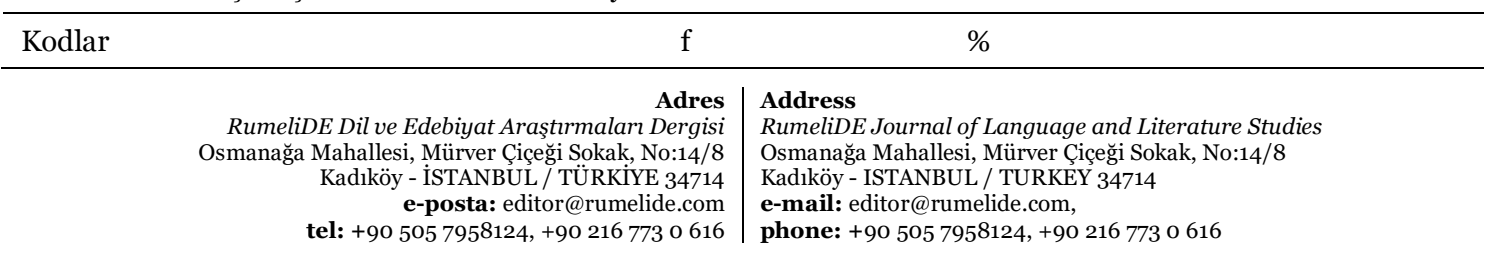




\begin{tabular}{lll}
\hline Temel & 41 & 97,62 \\
\hline Orta & 1 & 2,38 \\
\hline TOPLAM & 42 & 100,00 \\
\hline
\end{tabular}

Tablo 8 incelendiğinde katılımcıların 41’i $(\% 97,62)$ uzaktan eğitimde temel dil düzeyindeki öğrencilerle dersin işlenişinde zorluk yaşadığını belirtmiştir. 1 katılımcı $(\% 2,38)$ ise orta dil düzeyindeki öğrencilerle dersin işlenişinde zorluk yaşadığını belirtmiştir. Temel düzeyde zorluk yaşadıklarını belirten katılımcıların örnek görüşleri şöyledir.

K14: Elbette A1 seviyesi özellikle yurt dışında olup tek kelime Türkçeye maruz kalmayan, üstelik haftada 30 saat Türkçe öğrenip öğrendikleri uygulama şansı bulamayan öğrencilerle çok daha fazla zorlanıyorsunuz. A1 seviyesi beden dilini de en çok kullandığımız seviye hiç temeli olmayan öğrencilere açıklama yapmak mümkün değil.

K22: A1 düzeyinde öğrencilere uzaktan eğitim ile ders içeriği aktarmak oldukça zordur. Beden dilini kullanarak aktarılmak istenen bilgileri ekran karşısında vermek oldukça zordur. Öğrencilerle yeni tanışmak, onların art alan bilgileri hakkında bilgi sahibi olmamak zor bir süreçtir, sürekli materyal hazırlamak, onların dersi anlaması için içerikleri yeniden düzenlemek oldukça yorucu ve zaman ahııdır. Ao olarak bile adlandırdığımız öğrencilere yüz yüze olmadan temel seviye bilgileri aktarmak gerçekten çok zor.

Orta düzeyde zorluk yaşadığını belirten katılımcının görüşü şöyledir.

K27: Ben bu soru için çoğu kişiden farklı olacaktır belki ama B1 seviyesi diyebilirim.

Elde edilen bulgular, katılımclların uzaktan eğitimde temel dil düzeyindeki öğrencilerle dersin işlenişinde zorluk yaşadığını göstermiştir. Beden dilinin en çok işe koşulduğu bir dil seviyesinde katılımcıların uzaktan eğitimde güçlük çekmesi anlaşılır bir durum olarak değerlendirilebilir.

\subsection{Uzaktan yabancılara Türkçe öğrenenlerin Türkçeyi öğrenme motivasyonlarına ilişkin bulgular}

Katılımcıların “Uzaktan eğitim sürecinde öğrencilerin Türkçeyi öğrenme motivasyonları nasıl değişti?” sorusuna ilişkin verdikleri yanıtlardan elde edilen bulgular Tablo 9’da gösterilmektedir.

Tablo 9. Türkçe Öğrenme Motivasyonu Durumları

\begin{tabular}{lll}
\hline Kodlar & $\mathrm{f}$ & $\%$ \\
\hline Motivasyonun düşmesi & 29 & 72,50 \\
\hline Motivasyonun artması & 6 & 15,00 \\
\hline Motivasyonda değişiklik yok & 5 & 12,50 \\
\hline TOPLAM & 40 & 100,00 \\
\hline
\end{tabular}

Tablo 9 incelendiğinde katılımcıların 29'u $(\% 72,50)$ uzaktan yabancllara Türkçe öğretiminde öğrencilerin Türkçe öğrenme motivasyonlarının düştüğünü, 6’sı (\%15) öğrencilerin Türkçe öğrenme motivasyonlarının arttığını, 5 ’ $(\% 12,50)$ ise öğrencilerin Türkçe öğrenme motivasyonlarında değişiklik olmadığını belirtmiştir.

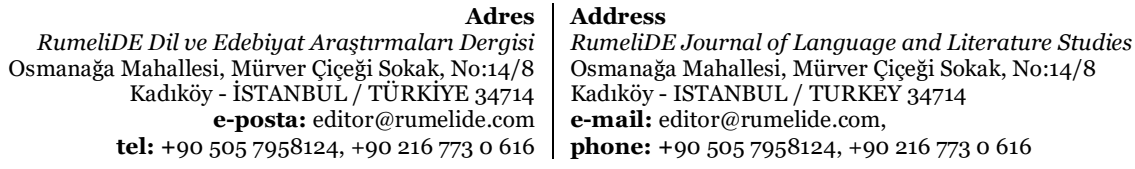


Uzaktan yabancılara Türkçe öğretiminde öğrencilerin Türkçe öğrenme motivasyonlarının düştüğünü belirten katılımcı $(\mathrm{n}=29, \% 72,50)$ görüşleri şöyledir.

K5: Öğrencilerin öğrendikleri dile ait ülkeyle, kültürle tanışmamış olmaları motivasyonların olumsuz yönde etkilemektedir.

K12: Motivasyon kaybr yaşadılar, yaşıyorlar. Bazen bir ödevi yapmaları gerektiğini bir iki defa hatırlatmak zorunda kahyorum. Bu durum öğrenciden öğrenciye değişse de genel anlamda öğrenciler yüz yüze eğitime geçilmesini istiyorlar, uzaktan eğitim ile dil öğrenmekte zorlandıklarmı ifade ediyorlar.

K15: Sinıf ortaminda öğrenci özellikle de üniversite bünyesinde hem daha istekli hem de öğrenme merakı daha üst düzey olmaktadır. Ancak sinıf ortamında dahi olsa öğrencinin motivasyonunda ya da isteğinde eksiklik görüldü̆̈̈u yerlerde çeşitli şekillerde öğrenci motive ediliyor ve Türkçeye olan ilgili artırılmaya çalş̧ılıyor. Ancak şu an öğrenciler ile iletişimimiz de sadece online ya da telefon vasttası ile olduğu için onları ve onlarm içinde bulundukları gözlemleyip müdahale etmek çok da kolay olmuyor.

K16: Bazı öğrenciler dili öğrenemeyecekleri, bu dilin çok zor olduğu kanaatine kapıldılar. Çünkü pek çok öğrencimi Türkiye'de değil ve pratik yapma şansina erişemiyorlar.

K22: Öğrencilerin elbette yüz yüze eğitimde yapılan derslerdeki gibi motivasyonlarmın olmadiğı aşikâr. Kimi öğrencilerin tükenmişlik sendromu yaşadiğını görebiliyordum ya da hissedebiliyordum. Derslere girmeyi reddetme, ilgi eksikliği, yüz yüze eğitimde öğrencilerde olan disiplinin maalesef olmaması gibi durumlar gözlemlenmiştir. Hatta yüz yüze eğitimde hazrrlanı okula gelme durumunun yerini, üzerini bile değiştirmeden ekran karşısına geçme, hazırlanmama (saç taramama gibi, başörtüsü takan öğrencilerin hazır olmadıklarmı söyleyip kamera açmama isteği vb.), kamera karşısında yatarak ders dinleme gibi disiplin bozuklukları ortaya çıkmıştır. Öğrenme istekleri ise yüz yüze eğitime oranla azalmıştır.

K41: Olumsuz yönde değiş̧i. Teknolojik sorun yaşayanlar derse katılamamaktadır. Bu da motivasyon düşüklüğüne sebep olmaktadır.

Öğrencilerin Türkçe öğrenme motivasyonlarının arttığını belirten katılımcı görüşleri ( $n=6, \% 15)$ şöyledir.

K4: Olumlu yönde etkiledi bence. Çünkü ilk başlarda uzaktan eğitimle Türk öğrenememe kaygısı vardı. Bu kaygı da öğrencileri ders çalş̧maya itti. Bu durum net bir şekilde gözlemlendi.

K5: İlk başta zorluklar, derse karşı tutumlar olumsuz olsa da uzaktan eğitime alşstıktan sonra öğrencilerin motivasyonları -gözlemlerime göre- iyi durumda. Öğrenci derse katılamasa da üniversite sistemi üzerinden ders kaydını izleyebilmesinin, katılamadığı ya da anlayamadiğı dersi defalarca dinleyebilmesinin öğrencilerin Türkçe öğrenme motivasyonlarmı olumlu yönde etkilediğini düşünüyorum.

K28: Mesafe dolayısıyla derse gelmekte zorlanan öğrenciler evlerinde derse girmek mümkün olduğunda motivasyon artışı gözlemledim.

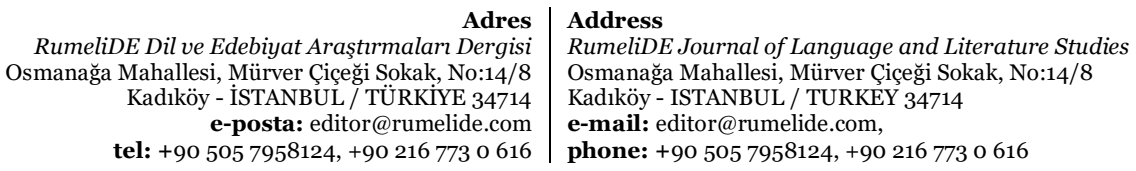


Uzaktan eğitim sürecinde öğrencilerin Türkçe öğrenme motivasyonlarında herhangi bir değişiklik gözlemlemediklerini belirten katılımcı görüşleri $(n=5, \% 12,50)$ şöyledir.

K9: Derse düzenli devam eden ve aksatmadan ödevlerini yapıp gönderen öğrencilerin motivasyonlarmda herhangi bir düşüklük olduğunu düşünmüyorum.

Kıo: Herhangi bir motivasyon kaybı görmedim. Verilen ödevleri titizlikle yaptılar. Devam ve derse katılım düzeyleri iyiydi.

K33: Ben yüz yüze öğretim arasında bir fark olduğunu düşünmüyorum. Burada istekli olan öğrencilerin aynı şekilde yüz yüze öğretimde de istekli olacakları beklentisi içerisindeyim. Bununla birlikte teknik olanakların kısıtlamaları ortadan kalkınca elbette bir kısım öğrencilerin yüz yüze öğretimde daha istekli hâle gelecekleri kanaatindeyim.

Elde edilen bulgular, uzaktan yabancılara Türkçe öğretiminde öğrencilerin Türkçe öğrenme motivasyonlarının düştüğünü göstermiştir. Bunun öğrencilerin yaşadıkları internet sorunları, yüz yüze eğitimi tercih etmeleri, kültürel etkinliklere katılamamaları, öğretmenleri ile olan iletişimin azalması, Türkçe öğrenmenin zor bir dil olduğuna inanmaları ve pratik yapma imkânlarının olmamasından kaynaklı ortaya çıktığı belirlenmiştir. Öğrencilerin Türkçe öğrenme motivasyonlarının arttığını belirten katılımcılar bu durumun öğrencilerdeki dil öğrenme kaygısının onları çalışmaya itmesine, ders kayıtlarını tekrar izleyebilme imkânına sahip olmalarına ve mesafeden dolayı yüz yüze eğitimde zorluk yaşayan öğrencilerin uzaktan eğitimde kolaylık yaşamalarına bağlamışlardır. Uzaktan eğitim sürecinde öğrencilerin Türkçe öğrenme motivasyonlarında herhangi bir değişiklik gözlemlemediklerini belirten katılımcılar ise bilinçli öğrencilerin her şartta hedefe yönelik davrandıklarını belirtmişlerdir.

\subsection{Uzaktan yabancılara Türkçe öğretiminde öğrencilerin Türkçeyi öğrenme motivasyonlarını artırmada kullanılan yöntem, teknik ve uygulamalara ilişkin bulgular}

Katılımcıların "Öğrencilerin Türkçeyi öğrenme motivasyonlarını artırmak için kullandığınız yöntem, teknik ya da uygulamalar nelerdir?” sorusuna ilişkin verdikleri yanıtlardan elde edilen bulgular Tablo 10'da gösterilmektedir.

Tablo 10. Öğrencilerin Türkçeyi Öğrenme Motivasyonlarını Artırmada Kullanılan Yöntem, Teknik ve Uygulamalar

\begin{tabular}{|c|c|c|}
\hline Kodlar & $\mathrm{f}$ & $\%$ \\
\hline Hedef dilde film/video/şarkı dinleme/izleme & 14 & 20 \\
\hline Sohbet etme & 8 & 11,42 \\
\hline Anında veya en kısa sürede dönüt & 5 & 7,14 \\
\hline Ödev verme & 4 & 5,71 \\
\hline Sınıf dışı etkinlikler & 4 & 5,71 \\
\hline Eğlenceli ders etkinlikleri tasarlama & 4 & 5,71 \\
\hline Gelecekle ilgili beklentide bulunma & 3 & 4,28 \\
\hline Pozitif yaklaşım & 3 & 4,28 \\
\hline Bireysel ilgilenme & 3 & 4,28 \\
\hline Mezun veya daha ileri seviyedeki öğrencilerle tanıştırma & 3 & 4,28 \\
\hline $\begin{array}{r}\text { Adres } \\
\text { RumeliDE Dil ve Edebiyat Arassturmaları Dergisi } \\
\text { Osmanağa Mahallesi, Mürver Ciçeği Sokak, No:14/8 } \\
\text { Kadıköy - İSTANBUL / TÜRKIYY } 34714 \\
\text { e-posta: editor@rumelide.com } \\
\text { tel: }+90 \text { 505 7958124, +90 216 773 o } 616\end{array}$ & \multicolumn{2}{|c|}{$\begin{array}{l}\text { Address } \\
\text { RumeliDE Journal of Language and Literature Studies } \\
\text { Osmanağa Mahallesi, Mürver Ciçeği Sokak, No:14/8 } \\
\text { Kadıköy - ISTANBUL / TURKEY } 34714 \\
\text { e-mail: editor@rumelide.com, } \\
\text { phone: +90 505 7958124, +90 } 216773 \text { o } 616\end{array}$} \\
\hline
\end{tabular}




\begin{tabular}{lll}
\hline Teşvik etme & 3 & 4,28 \\
\hline Kültürel örnekler & 3 & 4,28 \\
\hline Telkin etme & 3 & 4,28 \\
\hline Dil öğrenme amaçlarını hatırlatma/bildirme & 2 & 2,85 \\
\hline Başarılarını/gelişimlerini bildirme & 2 & 2,85 \\
\hline Derste öğrencilerin ilgi alanlarından örnekler verme & 2 & 2,85 \\
\hline Öğrenci seviyesini dikkate alma & 2,85 \\
\hline Ders kaynaklarını çeşitlendirme & 1 & 1,42 \\
\hline Ödüllendirme & 1 & 1,42 \\
\hline TOPLAM & 70 & 100,00 \\
\hline
\end{tabular}

Tablo 10 incelendiğinde katılımcıların 14'ü (\%20) uzaktan yabancılara Türkçe öğretiminde öğrencilerin Türkçe öğrenme motivasyonunu artırmak için hedef dilde film/video/şarkı dinleme veya izleme, 8’i $(\% 11,42)$ sohbet etme, 5’i $(\% 7,14)$ anında veya en kısa sürede dönüt verme, 4’ü $(\% 5,71)$ ödev verme, 4’ü sınıf dışı etkinlikler yapma, 4’ü $(\% 5,71)$ eğlenceli ders etkinlikleri tasarlama, 3 ’ü $(\% 4,28)$ gelecekle ilgili beklentide bulunma, 3’ü $(\% 4,28)$ pozitif yaklaşım sergileme, 3’ü $(\% 4,28)$ bireysel ilgilenme, 3 'ü $(\% 4,28)$ mezun veya daha ileri seviyedeki öğrencilerle tanıştırma, 3’ü $(\% 4,28)$ teşvik etme, 3’ü $(\% 4,28)$ kültürel örnekler gösterme, 3’ü $(\% 4,28)$ telkin etme, 2'si $(\% 2,85)$ dil öğrenme amaçlarını hatırlatma/bildirme, 2'si $(\% 2,85)$ öğrencilerin başarıların/gelişimlerini bildirme, 2'si $(\% 2,85)$ derste öğrencilerin ilgi alanlarından örnekler verme, 2'si $(\% 2,85)$ öğrenci seviyesini dikkate alma, 1’i $(\% 1,42)$ ders kaynaklarını çeşitlendirme, 1’i $(\% 1,42)$ ödüllendirme gibi yöntem/teknik ya da uygulamalar kullandıklarını belirtmişlerdir.

Uzaktan yabancllara Türkçe öğretiminde öğrencilerin Türkçe öğrenme motivasyonunu artırmak için hedef dilde film/video/şarkı dinleme etkinlikleri yaptıklarını belirten katılımcı görüşleri $(n=14, \% 20)$ şöyledir:

K1: Video izleme ve yorumlama, şarkı dinleme gibi online güdüleyiciler.

K9: Televizyonda bol bol Türkçe program izlemelerini öneriyorum. Bu bakımdan Türk dizilerinin sinırları aşması, alan için de olumlu bir durum oluşturuyor.

K11: Dinleme ve konuşma derslerinde bazı videolar izliyoruz. Motivasyonu artırdiğın düşünüyorum.

K12: Yukarıda bahsettiğim bağlama çalma ve türkü/şarkı söyleme, arkadaşlk kurdurma gibi faaliyetler öğrenme motivasyonların artırma çabalarm arasında.

Uzaktan yabancılara Türkçe öğretiminde öğrencilerin Türkçe öğrenme motivasyonunu artırmak için öğrencilerle sohbet ettiklerini belirten katılımcı görüşleri $(n=8,11,42)$ şöyledir.

K7: Kendileriyle hem ders içerisinde hem de ders dışarısında sohbet etmeye çalışarak gündemlerini değiştirecek önerilerde bulunmaya çalışıyorum.

K34: WhatsApp’n yararı oldu, görüntülü konuşmalarla motivasyonlarını olumlu düzeyde tutmaya çalıştım.

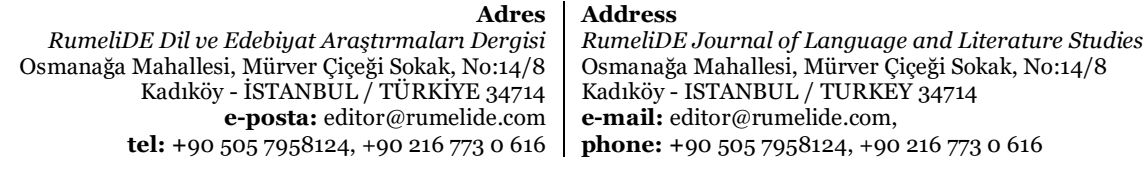


Uzaktan yabancllara Türkçe öğretiminde öğrencilerin Türkçe öğrenme motivasyonunu artırmak için öğrencilere anında veya en kısa sürede dönüt verdiğini belirten katılımcı görüşleri $(n=5, \% 7,14)$ şöyledir.

K3: yazma ve konuşma ödevlerine anlık veya en kısa sürede cevap vermek.

K19: Güdülenmenin en büyük hızlandırıcısı ise sıkı takip ve geri dönütlerdir. Öğrencilerin Türkçeyi öğrenme motivasyonların artırmak için izlediğim en önemli yöntem takip ve geri dönüt vermedir. Olumlu dönütler WhatsApp gruplarında veya sosyal medyada paylaşlmaktadır. Bu da öğrencinin motivasyonunu artormaktadir.

Uzaktan yabancllara Türkçe öğretiminde öğrencilerin Türkçe öğrenme motivasyonunu artırmak için öğrencilere ödev verdiğini belirten katılımcı görüssleri $(n=4, \% 5,71)$ şöyledir.

K1o: Sinavda ödevlerin ve katılımı etkili olması olabilir.

K23: Küçük ve orta çaph ödevler.

Uzaktan yabancllara Türkçe öğretiminde öğrencilerin Türkçe öğrenme motivasyonunu artırmak için öğrencilerle sınıf dışı etkinlikler yaptığını belirten katılımcı görüşleri $(n=4, \% 5,71)$ şöyledir.

K3: Öğrencilere 7/24 sosyal medya desteği vermek

K34: Her akşam gün değerlendirme aktiviteleri gerçekleştirdik

Uzaktan yabancllara Türkçe öğretiminde öğrencilerin Türkçe öğrenme motivasyonunu artırmak için eğlenceli ders etkinlikleri tasarladığını belirten katılımcı görüşleri $(n=4, \% 5,71)$ şöyledir.

K3: Ders içeriğini eğlenceli hale getirerek ilgi ve merak uyandırmak göstermek yaptıklarımız arasindadir.

K43: Ayrıca her insanm eğlenceyi oyunu sevdiğini düşünerek dersleri oyunlara dönüştürmeye çalışıyorum. Bilgi yarışmaları yaptırıyorum, bulmaca etkinlikleri yaptırıyorum.

Uzaktan yabancılara Türkçe öğretiminde öğrencilerin Türkçe öğrenme motivasyonunu artırmak için gelecekle ilgili beklentide bulunduklarını veya beklentileri hatırlattıklarını belirten katılımcı görüşleri $(\mathrm{n}=3, \% 4,28)$ şöyledir.

K4: Bir yıl sonra üniversite öğrencisi olacaklarından bu durumu sıklıkla hatırlatıyorum.

K33: Bu aslında ülkemizdeki yabancllara Türkçe öğretiminin genel sorunu. Öğrenci için Türk dilini öğrenmesi anlamh olmah. Onun hayatında işine yaradığın görmeli. Ben de bunun için her konuda mutlaka onun günlük hayatlarında, akademik hayatlarında, üniversiteden mezun olduktan sonra iş hayatlarında ne işlerine yarayacağın sezdirmeye çahşıyorum. Mesela seviye de biraz ilerlemişse karşılaştığımız yeni bir kelimenin tek bir anlamın öğretmiyorum. Bu kelimenin günlük hayattaki ve akademik hayattaki yeri hakknda örnekler veriyorum.

Uzaktan yabancllara Türkçe öğretiminde öğrencilerin Türkçe öğrenme motivasyonunu artırmak için pozitif bir yaklaşımda bulunduklarını belirten katılımcı görüşleri $(n=3, \% 4,28)$ şöyledir.

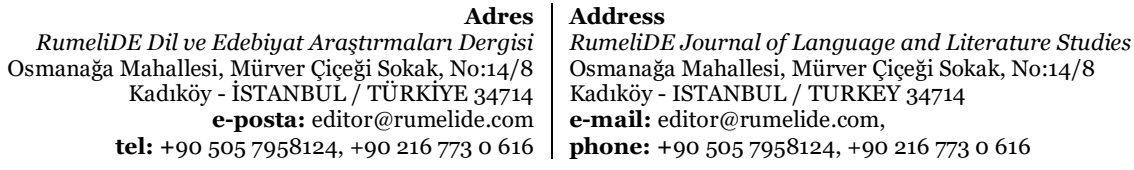


K22: Öğrencilere bu süreçte olabildiğince pozitif yaklaşmaya çahştım. Bu sürecin geçici olduğunu, küresel bir salgın olduğunu ve uzaktan eğitim alan şansh kişilerden oldukların vurgulamaya özen gösterdim.

K4o: Öncelikle öğrencilere her zamankinden daha fazla pozitif yaklaşmak, öğrenciyi kazanmak ve derse katmak açısından önem arz ediyor.

Uzaktan yabancllara Türkçe öğretiminde öğrencilerin Türkçe öğrenme motivasyonunu artırmak için öğrencilerle bireysel olarak ilgilendiğini belirten katılımcı görüşleri $(n=3, \% 4,28)$ şöyledir.

K22: Bireysel çalışmalar, kişiye özel uygulamalara yer verdim.

K24: Güne başlarken her biriyle kısa diyaloglar kurmak, onlarm yoklukları durumunda neden gelmediklerini sormak, ...vb.

K29: Dersten sonra her öğrencim ile bireysel görüşmeye çalıştım. Motivasyon yavaş yavaş arttı.

Uzaktan yabancllara Türkçe öğretiminde öğrencilerin Türkçe öğrenme motivasyonunu artırmak için mezun veya daha ileri seviyedeki öğrencilerle tanıştırdığını veya kat ettikleri seviyeleri gösterdiklerini belirten katılımcı görüşleri $(\mathrm{n}=3, \% 4,28)$ şöyledir.

K15: Ayrıca daha önceki kurlarda ya da dönemlerde ileri seviyeye gelmiş öğrencileri zaman zaman derse davet ederek, onları geldikleri seviyeyi anlatarak ilgilerini ve motivasyonlarmı yüksek tutmaya çalışıyoruz.

K16: Eski öğrencilerimin videolarını izletiyorum.

K30: Eski öğrencilerimi örnek göstermem.

Uzaktan yabancılara Türkçe öğretiminde öğrencilerin Türkçe öğrenme motivasyonunu artırmak için öğrencileri teşvik ettiğini belirten katılımcı görüşleri $(n=3, \% 4,28)$ şöyledir.

K6: Teşvik ediyoruz.

K35: Onları istenildiği taktirde her şekilde dil öğrenebilecekleri konusunda güdülemeye çalışmaktayım.

Uzaktan yabancılara Türkçe öğretiminde öğrencilerin Türkçe öğrenme motivasyonunu artırmak için Türk kültüründen örnekler verdiğini belirten katılımcı görüşleri $(n=3, \% 4,28)$ şöyledir.

K5: Bolca Türk kültüründen örnekler vermek.

K21: Öğrencilere sosyal hayattan ve sokak yaşantısından örnekler sunarak öğrendikleri dilin yaşadığın göstermek adına daha çok örneklemelerde bulundum.

Uzaktan yabancılara Türkçe öğretiminde öğrencilerin Türkçe öğrenme motivasyonunu artırmak için öğrencileri telkin ettiğini belirten katılımcı görüşleri $(n=3, \% 4,28)$ şöyledir.

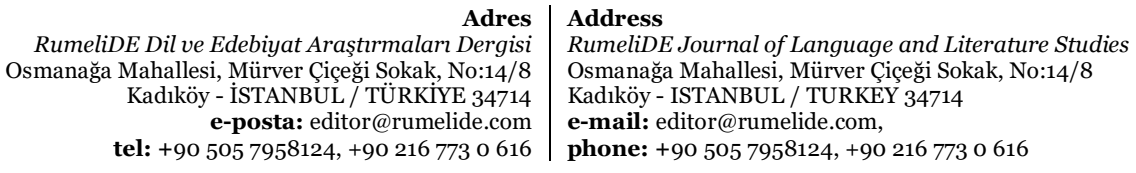


K2: Bunun için özel bir teknik ya da uygulamamı olmadı ama derslerimizin çoğunda bu süreci iyi değerlendirmek gerektiğini anlatarak onları motive etmeye çalışıyorum.

K22: Bu sürecin geçici olduğunu, küresel bir salgın olduğunu ve uzaktan eğitim alan şansh kişilerden oldukların vurgulamaya özen gösterdim.

Uzaktan yabancılara Türkçe öğretiminde öğrencilerin Türkçe öğrenme motivasyonunu artırmak için öğrencilerin dil öğrenme amaçlarını bildiren katılımcı görüşleri (n=2, \%2,85) şöyledir.

K6: Neden Türkçeyi öğrenmeleri gerektiğini hatırlatmaya çalşıyoruz. Bir amaçları olduğu noktasinda...

K33: Bu aslında ülkemizdeki yabancllara Türkçe öğretiminin genel sorunu. Öğrenci için Türk dilini öğrenmesi anlamlı olmalı. Onun hayatında işine yaradığın görmeli. Ben de bunun için her konuda mutlaka onun günlük hayatlarında, akademik hayatlarmda, üniversiteden mezun olduktan sonra iş hayatlarında ne işlerine yarayacağını sezdirmeye çalışıyorum.

Uzaktan yabancllara Türkçe öğretiminde öğrencilerin Türkçe öğrenme motivasyonunu artırmak için öğrencilerin başarılarını/gelişimlerini bildiren katılımcı görüşleri ( $n=2, \% 2,85)$ şöyledir.

K16: A1 ilk günü ve C1'den sonraki farkları ayrıca kendilerinin de ders kayıtların izletiyorum. Eski kayıtlar ve son durum.

K30: Ayrıca ilk derslerde kaydettiğim ders videoların öğrencilerin gelişimi açısından kendilerine izlettiriyorum ve farkı kendilerinin görmelerini sağhyorum.

Uzaktan yabancllara Türkçe öğretiminde öğrencilerin Türkçe öğrenme motivasyonunu artırmak için derste öğrencilerin ilgi alanlarından örnekler verdiğini bildiren katılımcı görüşleri $(n=2, \% 2,85)$ şöyledir.

K14: Öğrenicilerin motivasyonunu artırmak için öğrenicileri öğrenme sürecinin bir parçası hâline getirmeye özen gösteririm. Örneğ in bir yapı öğretiyorsam sinıftaki öğreniciler ve özellikleri üzerinden örnekler veririm. Videolar ve çeşitli etkinliklerle onlar ders dâhil ederim. Tüm öğrencilere söz vermeye çalşııım, onlarm ilgilerini çekecek konunlar üzerinde yoğunlaşırım.

K31: Öğrencilerin hobilerini ve özel ilgi alanlarmı öğrenip örneklerimi onlar üzerinden vermeye çalışıyorum. Bu genellikle futbol, müzik, sosyal medya fenomenleri vs. oluyor. Mesela "Alinin arabası" yerine Ronaldo'nun arabası...

Uzaktan yabancllara Türkçe öğretiminde öğrencilerin Türkçe öğrenme motivasyonunu artırmak için öğrencilerin seviyelerini dikkate aldığını bildiren katılımcı görüşleri $(n=2, \% 2,85)$ şöyledir.

K35: Burada önemli bir nokta da öğrencinin başarıyı tatmasıdır. Dil öğrenme süreci içerisinde her öğrencinin seviyesine uygun olarak etkinlikler verip onların motivasyonunu artırmaya çalsşıyorum.

K43: Öğrencilerin hepsi olmasa bile geneli başardıkça daha olumlu düşünüp derse devam ettikleri seviyelerine uygun basit uygulamalar yaptırarak öğrencilerin motivasyonunu arttırmaya çalışıorum.

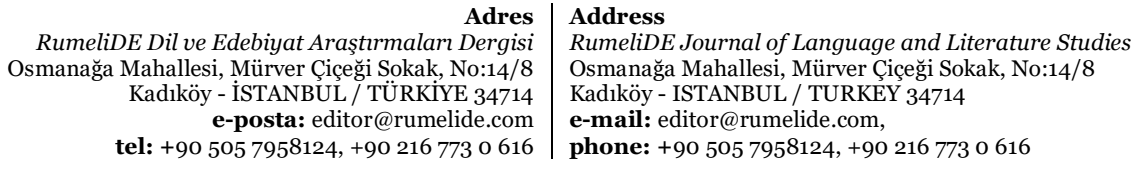


Uzaktan yabancllara Türkçe öğretiminde öğrencilerin Türkçe öğrenme motivasyonunu artırmak için ders kaynaklarını çeşitlendirdiğini bildiren katılımcı görüşü $(n=1, \% 1,42)$ şöyledir.

K4O: Ders kaynaklarını çeşitlendirmek ve öğrencilerle ders dışında iletişim kurmak gerekiyor.

Uzaktan yabancllara Türkçe öğretiminde öğrencilerin Türkçe öğrenme motivasyonunu artırmak için öğrencileri ödüllendirdiğini belirten katılımcı görüşleri (n=1, \%1,42) şöyledir.

K23: Ders esnasında öğrencilerin olumlu davranışlarına karşı pekiştireç kullanmak.

Elde edilen bulgular, katılımcıların öğrenci motivasyonlarını artırmak için pek çok yöntem, teknik ve etkinlik uyguladığını göstermiştir. Bunlar içinde katılımcıların en çok hedef dilde film/video/şarkı dinleme veya izleme etkinlikleri yapmaları, öğrencilerin hedef dilin kullanım örnekleri ile kültürel yaklaşımlarını görmeleri açısından önemlidir.

\subsection{Uzaktan yabancılara Türkçe öğretiminde öğrencilerin karşılaştıkları sorunlara ilişkin bulgular}

Katılımcıların "Uzaktan eğitim sürecinde öğrencilerin en çok hangi konularda sorun yaşadığını düşünüyorsunuz?” sorusuna ilişkin verdikleri yanıtlardan elde edilen bulgular Tablo 11'de gösterilmektedir.

\begin{tabular}{lll}
\hline Tablo 11. Öğrencilerin Karşılaştıkları Sorunlar & & $\%$ \\
\hline Kodlar & $\mathrm{f}$ & 47,61 \\
\hline İnternet bağlantısında yaşanan sorunlar & 40 & 11,90 \\
\hline Teknik donanım yetersizliğinden kaynaklanan sorunlar & 10 & 9,52 \\
\hline Dijital okuryazarlık yetersizliğinden kaynaklanan sorunlar & 8 & 4,76 \\
\hline Sisteme alışma sorunları & 4 & 3,57 \\
\hline Bilgisayar kullanmamaktan kaynaklanan sorunlar & 3,57 \\
\hline Özerk öğrenme becerilerinin yetersizliğinden kaynaklanan sorunlar & 3 \\
\hline Klavye kullanamamaktan kaynaklanan sorunlar & 3,57 \\
\hline Ekran yorgunluğundan kaynaklanan sorunlar & 3 \\
\hline Ev ya da yurt ortamının uygun olmamasından kaynaklanan sorunlar & 3,57 \\
\hline İnternetin pahalıl̆ğından kaynaklanan sorunlar & 2 & 2,38 \\
\hline Saat farkından kaynaklanan sorunlar & 2 & 2,38 \\
\hline Dilin kültürel ortamından uzaklı̆̆ndan kaynaklanan sorunlar & 2 \\
\hline Zaman yönetiminin yetersizliğinden kaynaklanan sorunlar & 2,38 \\
\hline Elektrik kesintisinden kaynaklanan sorunlar & 1 & 1,19 \\
\hline Uzaktan eğitime yönelik negatif bakış açısından kaynaklanan sorunlar & 1 \\
\hline TOPLAM & 1,19 \\
\hline
\end{tabular}

Tablo 11 incelendiğinde katılımcıların 40’ı $(\% 47,61)$ öğrencilerin internet bağlantısında yaşanan sorunlar, 10’u (\%11,90) teknik donanım yetersizliğinden kaynaklanan sorunlar, 8’i $(\% 9,52)$ dijital okuryazarlık yetersizliğinden kaynaklanan sorunlar, 4’ü $(\% 4,76)$ sisteme alışma sorunları, 3’ü $(\% 3,57)$

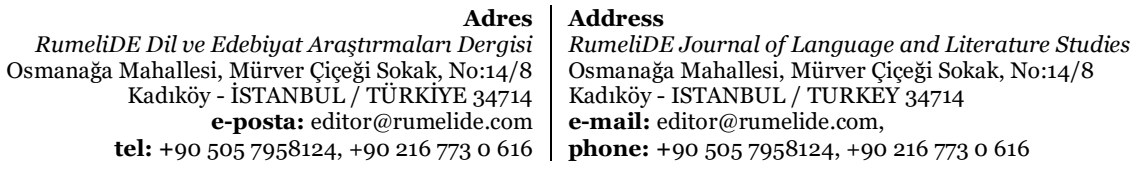


bilgisayar kullanmamaktan kaynaklanan sorunlar, 3’ü (\%3,57) özerk öğrenme becerilerinin yetersizliğinden kaynaklanan sorunlar, 3’ü $(\% 3,57)$ klavye kullanamamaktan kaynaklanan sorunlar, 3 ’ü $(\% 3,57)$ ekran yorgunluğundan kaynaklanan sorunlar, 2'si $(\% 2,38)$ ev ya da yurt ortamının uygun olmamasından kaynaklanan sorunlar, 2'si $(\% 2,38)$ internetin pahalılı̆̆ından kaynaklanan sorunlar, 2'si $(\% 2,38)$ saat farkından kaynaklanan sorunlar, 1’i $(\% 1,19)$ dilin kültürel ortamından uzaklığından kaynaklanan sorunlar, 1’i (\%1,19) zaman yönetiminin yetersizliğinden kaynaklanan sorunlar, 1’i $(\% 1,19)$ elektrik kesintisinden kaynaklanan sorunlar, 1’i $(\% 1,19)$ uzaktan eğitime yönelik negatif bakış açısı gibi sorunlarla karşılaştıklarını belirtmiştir.

Elde edilen bulgulara göre, katılımcıların 40’ı $(\% 47,61)$ öğrencilerin uzaktan yabancılara Türkçe öğretiminde internet bağlantısından kaynaklanan sorunlar yaşadıklarını belirtmiştir.

K2o: Öğrenciler sürekli internetin zayıf olmasından şikâyet ediyorlar.

K35: Uzaktan eğitimde öğrencilerin bir kısmı internet bağlantısı sorunu yaşamaktalar. Bu sorun onların derse bağlanmaları ve ders boyunca derste olmalarmı etkilemektedir.

Tablo 11 incelendiğinde katılımcıların 10'u (\%11,90) öğrencilerin uzaktan yabancılara Türkçe öğretiminde teknik donanım yetersizliğinden kaynaklanan sorunlar yaşadıklarını belirtmiştir.

K9: Bazı ülkelerde uygulanan koruyucu filtreler, teknik donanım sıkıntısı bizlerin de müdahale edip çözemeyeceği problemlerin başında yer alyor.

K19: Fakat bilgisayar, kamera, mikrofon, internet gibi gereksinimler maalesef birçok öğrenci tarafindan karşılanamamıştır. Internet salonlarında, iş yerlerinde, yakmlarmın bilgisayarlarında/internetlerinde derse katılan öğrencilerimiz birkaç hafta sonra zorlanacaklarmı belirtmişlerdir. Dolayısıyla bilgisayar, kamera, mikrofon, internet imkânlarının sağlanabilmesi için birçok öğrenci ekonomik sorun yaşadiğım belirterek derslere devam edememe durumlarıyla karşılaşmıştır. Bu durum da öğrencilerin derslerden uzak kalmalarına ve Türkçeden uzaklaşmalarına neden olmuştur.

Tablo 11 incelendiğinde 8, katılımcı $(\% 9,52)$, öğrencilerin uzaktan yabancılara Türkçe öğretimi sürecinde dijital okuryazarlık yetersizliğinden kaynaklanan sorunlar yaşadıklarını belirtmiştir.

K2O: Dijital okur yazarlk,

K38: Bununla birlikte dijital okur yazarlğında düşük olması süreçte yorucu ve eğitimi sekteye uğratıcı sıkıntılara neden olmaktadir.

Elde edilen bulgulara göre katılımcıların 4’ü $(\% 4,76)$ uzaktan yabancılara Türkçe öğretimi sürecinde sisteme alışma sorunu yaşadıklarını belirtmiştir.

K2: Yeni bir platforma alş̧ma süreci, öğrencilerin bazılarının kullandiğımız iletişim kanalların kullanmaması gibi.

K25: Dersin linkini paylaştığımız e-ders sistemine ve sinav soruların paylaştı̆̆ımız Office 365 uygulamasina girmede yetersizlikler gibi sorunlar var.

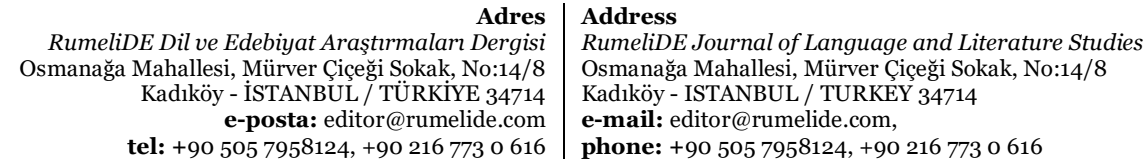


Tablo 11 incelendiğinde katılımcıların 3’ü $(\% 3,57)$ öğrencilerin uzaktan yabancılara Türkçe öğretimi sürecinde bilgisayarı kullanmamaktan kaynaklanan sorunlar yaşadığını belirtmiştir.

K5: Problem yaşadığımız bir konu, öğrencinin bilgisayarının bulunmaması.

K4o: Bilgisayardan mahrum olmak.

Tablo 11 incelendiğinde katılımclların 3’ü $(\% 3,57)$ öğrencilerin uzaktan yabancılara Türkçe öğretimi sürecinde özerk öğrenme becerilerinin yetersizliğinden kaynaklanan sorunlar yaşadıklarını belirtmiştir.

\section{K1: Öz disiplin.}

K7: En temel sorunlarmm özerk öğrenme becerilerinin gelişmemiş olduğunu ... söyleyebilirim.

K43: En önemli problem bir eğitim süreci içerisinde olduklartmı fark etmemeleri.

Elde edilen bulgulara göre katılımcıların 3’ü $(\% 3,57)$ öğrencilerin uzaktan yabancılara Türkçe öğretimi sürecinde klavye kullanamamaktan kaynaklanan sorunlar yaşadıklarını belirtmiş̧tir.

K3: Bir de öğrencilerin klavye ile yazmaları onları zorladı.

K14: Onun dışında yaşı büyük öğrencilerde uygulamaları ve klavyeyi kullanma sorunları ile karşılaştık. Klavyesinde Türkçe harflerin bulunmamasından kaynakh sorunlar yaşadık. Klavyesinde Türkçe harflerin bulunmamasından kaynakl sorunlar yaşadık.

Elde edilen bulgulara göre katılımcıların 3’ü $(\% 3,57)$ uzaktan yabancılara Türkçe öğretimi sürecinde öğrencilerin ekran yorgunluğundan kaynaklanan sorunlar yaşadıklarını belirtmiştir.

K6: Ekran başında uzun süreli olmaları daha olumsuz etkiliyor.

K43: Bir ekrana dakikalarca hatta saatlerce bakmak belli bir süre sonra stradanlaşlyor bu da öğrencinin motivasyonunu ve dikkatini olumsuz etkiliyor.

Tablo 11 incelendiğinde katılımcıların 2'si $(\% 2,38)$ öğrencilerin uzaktan yabancılara Türkçe öğretimi sürecinde ev ya da yurt ortamının uygun olmamasından kaynaklanan sorunlar yaşadıklarını belirtmiştir.

K24: Bulunduklarl yurtlarda veya evlerde sessiz olmayan ortamlar.

K26: Ayrıca öğrenciler odalarında derslere katılıyorlardı aynı anda arkadaşının dersleri oluyordu. Odalarında fazlaca ses vardı. Bazen odalarma arkadaşları dahil oluyordu. Böyle olunca öğrenci mikrofonunu açmak istemiyordu. Derse katılımları düşüyordu ve dikkatleri çok fazla dağılıyordu.

Tablo 11 incelendiğinde katılımcıların 2'si $(\% 2,38)$ uzaktan yabancılara Türkçe öğretimi sürecinde öğrencilerin internetin pahalılı̆̆ından kaynaklanan sorunlar yaşadıklarını belirtmiştir.

K4: İnternetin pahahılı̆ı gibi durumlar da var. Derslerine girdiğim öğrenciler burslu öğrenciler. Bu öğrencilerin birçoğu da Asya ve Afrika'da yaşamaktadır. Bu nedenle genel sıkıntılar bu kıtalarda yaşayan öğrencilerde görülüyor.

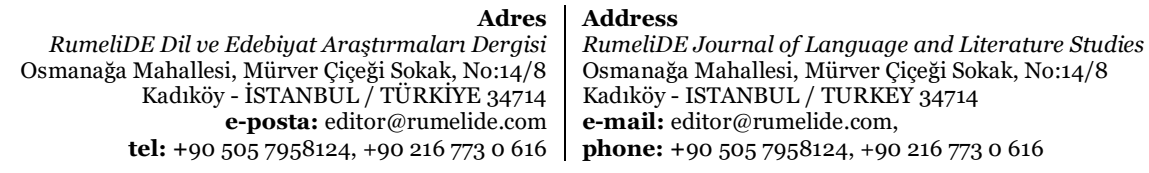


K18: İnternet erişiminin bulunulan ülkede pahah olması.

Elde edilen bulgulara göre katılımcıların 2'si $(\% 2,38)$ uzaktan yabancılara Türkçe öğretimi sürecinde öğrencilerin saat farkından kaynaklanan sorunlar yaşadığını belirtmiştir.

K14: Ayrıca saat farkı da yurt dışındaki öğrenciler için sorun yaratmakta.

K40: Yurt dışındaki öğrencilerle oluşan saat farkı.

Elde edilen bulgulara göre katılımcıların 1’i $(\% 1,19)$ uzaktan yabancılara Türkçe öğretimi sürecinde öğrencilerin dilin kültürel ortamının uzaklığından kaynaklanan sorunlar yaşadıklarını belirtmiştir.

K40: Dilin kültürel ortamindan mahrum kalmak.

Elde edilen bulgulara göre katılımclların 1’i $(\% 1,19)$ uzaktan yabancılara Türkçe öğretimi sürecinde öğrencilerin zaman yönetiminden kaynaklanan sorunlar yaşadığını belirtmiştir.

\section{K1: Zaman yönetimi.}

Elde edilen bulgulara göre katılımcıların 1’i $(\% 1,19)$ uzaktan yabancılara Türkçe öğretimi sürecinde öğrencilerin elektrik kesintisinden kaynaklanan sorunlar yaşadığını belirtmiştir.

\section{K4: Bununla birlikte elektrik kesintisi.}

Elde edilen bulgulara göre katılımclların 1’i $(\% 1,19)$ uzaktan yabancılara Türkçe öğretimi sürecinde öğrencilerin uzaktan eğitime yönelik negatif bakış açısından kaynaklanan sorunlar yaşadıklarını belirtmiştir.

K23: Uzaktan eğitime önyargılı yaklaşım.

\subsection{Uzaktan yabancılara Türkçe öğretiminde kur atlama sınavlarında yaşanan sorunlara ilişkin bulgular}

Katılımcıların "Uzaktan Türkçe öğretimi sürecinde kur atlama sınavlarında yaşanan sorunlar nelerdir?" sorusuna ilişkin verdikleri yanıtlardan elde edilen bulgular Tablo 12’de gösterilmektedir.

Tablo 12. Kur Atlama Sinavlarında Yaşanan Sorunlar

\begin{tabular}{lll}
\hline Kodlar & $\mathrm{f}$ & $\%$ \\
\hline Etik sorunlar & 23 & 28,75 \\
\hline İnternet bağlantısından kaynaklanan sorunlar & 23 & 28,75 \\
\hline Teknolojik yetersizliklerden kaynaklanan sorunlar & 10 & 12,50 \\
\hline Öğrencilerin sınav sistemini anlamamasından kaynaklı sorunlar & 9 & 11,25 \\
\hline Sinav sisteminden kaynaklanan sorunlar & 5 & 6,25 \\
\hline Sinavın geçerliğinden kaynaklanan sorunlar, & 3 & 3,75 \\
\hline Klavye kullanamamaktan kaynaklanan sorunlar & 2 & 2,50 \\
\hline Öğrencilerin sinava katılmamasından kaynaklanan sorunlar & 1 & 1,25 \\
\hline
\end{tabular}

\footnotetext{
\begin{tabular}{r|l} 
Adres & Address \\
RumeliDE Dil ve Edebiyat Araştırmaları Dergisi & RumeliDE Journal of Language and Literature Studies
\end{tabular} Osmanağa Mahallesi, Mürver Çiçeği Sokak, No:14/8 $\quad$ Osmanağa Mahallesi, Mürver Çiçeği Sokak, No:14/8 Kadıköy - ÍSTANBUL / TÜRKIYE 34714 Kadıköy - ISTANBUL / TURKEY 34714 e-posta: editor@rumelide.com e-mail: editor@rumelide.com, tel: +90 505 7958124, +90 2167730616 phone: +90 505 7958124, +90 2167730616
} 


\begin{tabular}{lll}
\hline Öğrencilerin kaygı durumundan kaynaklanan sorunlar & 1 & 1,25 \\
\hline Gözlem yetersizliğinden kaynaklanan sorunlar & 1 & 1,25 \\
\hline Sinav süresinin uzamasından kaynaklanan sorunlar & 1 & 1,25 \\
\hline Elektrik kesintisinden kaynaklanan sorunlar & 1 & 1,25 \\
\hline TOPLAM & 80 & 100,00 \\
\hline
\end{tabular}

Tablo 12 incelendiğinde katılımclların 23’ü $(\% 28,75)$ kur sınavlarında en çok etik sorunlar, 23’ü $(\% 28,75)$ internet bağlantısından kaynaklanan sorunlar, 10’u $(\% 12,50)$ teknolojik yetersizliklerden kaynaklanan sorunlar, 9’u (\%11,25) öğrencilerin sınav sistemini anlamamasından kaynaklı sorunlar, 5’i $(\% 6,25)$ sınav sisteminden kaynaklanan sorunlar, 3’ü (\%3,75) sınavın geçerliğinden kaynaklanan sorunlar, 2'si $(\% 2,50)$ klavye kullanamamaktan kaynaklanan sorunlar, 1’i $(\% 1,25)$ öğrencilerin sınava katılmamasından kaynaklanan sorunlar, 1’i $(\% 1,25)$ öğrencilerin kaygı durumundan kaynaklanan sorunlar, 1’i $(\% 1,25)$ gözlem yetersizliğinden kaynaklanan sorunlar, 1’i $(\% 1,25)$ sinav süresinin uzamasından kaynaklanan sorunlar, 1 i $(\% 1,25)$ elektrik kesintisinden kaynaklanan sorunlar yaşandığını belirtmiştir.

Tablo 12 incelendiğinde katılımcıların 23’ü $(\% 28,75)$ kur sınavlarında etik sorunlar yaşandığını belirtmiştir.

K4: Bu durumların dışında bazı öğrencilerin kopya çekme girişimleri de yaşanıyor. Sinıf içi performansı on üzerinden üç olan bir öğrenci sinavda on üzerinden dokuz alabiliyor. Her ne kadar kamera sistemiyle öğrenci takibi sağlansa da farklı yöntemlerle öğrenciler kopya girişimine başvuruyor.

K14: Biz sınavları safe exam browser ile ekran kilitleyerek, zoom üzerinden öğrencileri takip ederek üniversitemizin geliştirdiği bir sistem üzerinden sinav yapıyoruz. Ancak yine de öğrencilerin kopya çekmesine mâni olamıyoruz ve bir şekilde sinav güvenliğini sağlamak güçleşiyor.

K19: Ayrıca uzaktan eğitim modelinde sinavlarm internet ortamında olması da ahlaki bir sorunla karşılaşmamıza neden olmuştur. Sinavların gözetimli ve denetimli yapılmasını gerekliliği ifade edildiğinde öğrenciler tarafindan ekonomik, teknik, ağllk vb. sebepler öne sürülerek itiraz edilmiştir. Gözetimsiz (kamerasız) sinavlar yapıldığında ise bir öğrenciye ait kullanıcı bilgileri ile başka bir (farkh IP ile) yerden sinava girildiği tespit edilmiştir. Bu durum öğretmen tarafindan öğrenciye iletildiğinde hoşa gitmeyen diyaloglar yaşanmıştır. Öğrenciler sinav usullerine uygun olmayan farkh yöntemler deneyerek sınavların tamamlamıştır. Bu durumlar tespit edilmiş ve öğrencilerin sınavları iptal edilmiştir.

Tablo 12 incelendiğinde katılımcıların 23’ü $(\% 28,75)$ kur sinavlarında internet bağlantısından kaynaklanan sorunlarını yaşadığını belirtmiştir.

\section{K1: İnternet bağlantılarından kaynaklı sıkıntılar}

K4: Genellikle teknik sorunlar yaşanıyor (internet bağlantısı gibi).

K25: Genel olarak öğrencilerin bağlantı sorunları.

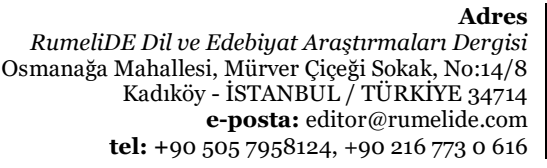

Adres
RumeliDE Dil ve Edebiyat Araştırmaları Dergisi
Osmanağa Mahallesi, Mürver Çiçeği Sokak, No:14/8
Kadıköy - İSTANBUL / TÜRKIYE 34714
e-posta: editor@rumelide.com
tel: +90 505 7958124, +90 216 7730616
Address

RumeliDE Journal of Language and Literature Studies

Osmanağa Mahallesi, Mürver Çiçeği Sokak, No:14/8

Kadıköy - ISTANBUL / TURKEY 34714

e-mail: editor@rumelide.com,

phone: +90 5057958124, +90 2167730616 
Tablo 12 incelendiğinde katılımclların 10’u (\%12,50) kur sınavlarında teknolojik yetersizliklerden kaynaklanan sorunlar yaşandı̆̆ını belirtmiştir.

K5: teknolojik yetersizlik sorunlarl.

K25: dijital araçlarda sorunlar

K30: öğrencilerin yeterli teknolojiye sahip olmaması.

Tablo 12 incelendiğinde katılımcıların 9’u (\%11,25) kur sınavlarında Öğrencilerin sınav sistemini anlamamasından kaynaklanan sorunlar yaşandığını belirtmiştir.

K1: Öğrencilerin sınav sistemini anlama ve sınav sistemine şifreli giriş yapma konusundaki sıkntıları.

Kı: Sisteme yabancı olmak. Sisteme girerken sorun yaşayan öğrencilerin morali bozuluyor. Bazen de sınavın ortasında yanlş̧lkla sistemden çıkıyorlar. Tekrar sınava giremiyorlar.

K27: Soruları nasıl cevaplayacaklarn ve cevaplar nereye kaydedeceklerini anlamakta zorluk yaşıyorlar.

Tablo 12 incelendiğinde katılımcıların 5’i $(\% 6,25)$ kur sınavlarında sınav sisteminden kaynaklanan sorunlar yaşandı̆̆ını belirtmiştir.

K6: Online sınavda sinavdan yanlş̧lkla atılma sorunu çok yüksek. Yanlsşlıkla bitti denildiğinde girişin olmaması, geçilen soruya geri dönememek

K8: Konuşma sınavında öğrenci konuştuğunu söylüyor ancak kayıt yok. Yazmada da benzer şeyler. Sağlkh işleyen bir sinav sistemimizin olmayışı ülkece en büyük sorun.

K1O: Bazen de sinavın ortasında yanlş̧lkla sistemden çıkıyorlar. Tekrar sınava giremiyorlar.

Tablo 12 incelendiğinde katılımcıların 3’ü $(\% 3,75)$ kur sınavlarında sınavın geçerliğinden kaynaklanan sorunu yaşandığını belirtmiştir.

K22: Uzaktan girdikleri sinavlarda sınıf düzeyinde başarısız olan öğrencilerin kur sinavlarında başarılı oldukları görülmüştür. Bu bağlamda özellikle ölçme değerlendirme alanında geçerli sinavlardan bahsetmek mümkün değildir.

K23: Sinavda mesafe temelli kopyanın geçerlik güvenirliği zedelemesi.

Tablo 12 incelendiğinde katılımcıların 2'si $\quad(\% 2,50)$ kur sınavlarında öğrencilerin klavye kullanamamaktan kaynaklanan sorunlar yaşandığını belirtmiştir.

K3: öğrencilerin yazma sınavında karşılaştıkları klavye sıkıntısı.

Tablo 12 incelendiğinde katılımcıların 2'si $(\% 2,50)$ kur sinavlarında öğrencilerin sinava katılmamalarından kaynaklanan sorunlar yaşandığını belirtmiştir.

K26: Sinava zamaninda gelmeme ya da hiç gelmeme gibi problemlerle karşılaştık.

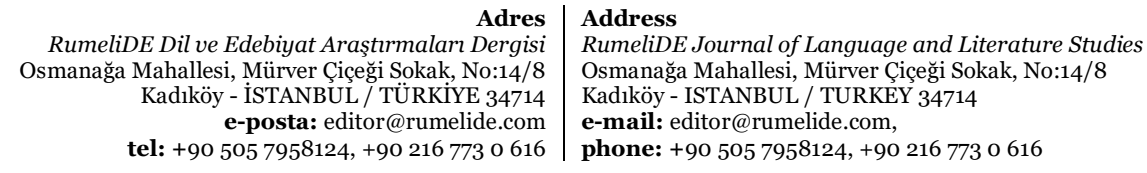


Tablo 12 incelendiğinde katılımcıların 2'si (\%2,50) kur sınavlarında öğrencilerin kaygı durumlarından kaynaklanan sorunlar yaşandığını belirtmiştir.

K4: Bunun dışında kayg düzeyleri daha fazla oluyor. Ancak A1’de sistemi gördükten sonra diğer seviyelerde daha rahat oluyor.

Tablo 12 incelendiğinde katılımcıların 1’i $(\% 1,25)$ kur sınavlarında gözlem yetersizliğinden kaynaklanan sorunlar yaşandığını belirtmiştir.

K43: En büyük problem gözlem problemidir. Ne kadar kamera açtırsak, süreyi stmırlandirsak bile gözlem sorununu çözememekteyim.

Tablo 12 incelendiğinde katılımcıların 1’i (\%1,25) kur sınavlarında sınav süresinin uzamasından kaynaklanan sorunlar yaşandığını belirtmiştir.

K32: Değerlendirme süresi uzadı. Zira her öğrenciyi ayr ayrl sinava aldık. Dinleme-konuşma, ardından okuma-yazma sinavları yaptık. Bir öğrenciyi değerlendirme süresi 20 dakikaya kadar uzayabildi.

Tablo 12 incelendiğinde katılımcıların 1’i $(\% 1,25)$ kur sınavlarında elektrik kesintisinden kaynaklanan sorunlar yaşandığını belirtmiştir.

K29: Öğrenci elektriğin kesildiğini söyleyebiliyor. Bu durumda o öğrencimizin sinavını başka bir güne erteliyoruz.

\subsection{Uzaktan yabancılara Türkçe öğretiminde öğreticilerin sıklıkla kullandığı ölçme ve} değerlendirme tekniklerine ilişkin bulgular

Katılımcıların "Öğrencilerin gelişimlerini takip etmek için uzaktan eğitimde sıklıkla kullandı̆̆ınız ölçme ve değerlendirme teknikleri nelerdir?” sorusuna ilişkin verdikleri yanıtlardan elde edilen bulgular Tablo 13'de gösterilmektedir.

\begin{tabular}{|c|c|c|}
\hline Kodlar & $\mathrm{f}$ & $\%$ \\
\hline Çoktan seçmeli maddeler & 23 & 19,33 \\
\hline Soru-cevap & 21 & 17,65 \\
\hline Boşluk doldurmalı maddeler & 19 & 15,97 \\
\hline Doğru-yanlış maddeleri & 9 & 7,56 \\
\hline Ödev & 9 & 7,56 \\
\hline Deneme sinavı & 8 & 6,72 \\
\hline Açık uçlu sorular & 8 & 6,72 \\
\hline Yazılı ürün değerlendirme & 6 & 5,04 \\
\hline Eşleştirme maddeleri & 3 & 2,52 \\
\hline Kontrol listeleri & 3 & 2,52 \\
\hline Okumayı değerlendirme & 2 & 1,68 \\
\hline $\begin{array}{r}\text { Adres } \\
\text { RumeliDE Dil ve Edebiyat Araşttrmaları Dergisi } \\
\text { Osmanağa Mahallesi, Mürver Ciçeği Sokak, No:14/8 } \\
\text { Kadıköy - İTANBUL / TÜRKIYE } 34714 \\
\text { e-posta: editor@rumelide.com } \\
\text { tel: }+90505 \text { 7958124, +90 216 } 7730616\end{array}$ & \multicolumn{2}{|c|}{$\begin{array}{l}\text { Address } \\
\text { RumeliDE Journal of Language and Literature Studies } \\
\text { Osmanağa Mahallesi, Mürver Cicceği Sokak, No:14/8 } \\
\text { Kadıköy - ISTANBUL / TURKEY } 34714 \\
\text { e-mail: editor@rumelide.com, } \\
\text { phone: +90 505 7958124, +90 } 216773 \text { o } 616\end{array}$} \\
\hline
\end{tabular}




\begin{tabular}{lll}
\hline Konuşma performansı değerlendirme & 2 & 1,68 \\
\hline Kelime havuzundan seçerek anlamlı cümle kurma & 1 & 0,84 \\
\hline Dikte & 1 & 0,84 \\
\hline Kısa cevaplı sorular & 1 & 0,84 \\
\hline Bulmaca & 1 & 0,84 \\
\hline Öğrenci ürün dosyası & 1 & 0,84 \\
\hline Süreç odaklı değerlendirme & 1 & 0,84 \\
\hline TOPLAM & 119 & 100,00 \\
\hline
\end{tabular}

Tablo 13 incelendiğinde katılımclların 23’ü $(\% 19,33)$ uzaktan yabancılara Türkçe öğretiminde çoktan seçmeli maddeler, 21’i $(\% 17,65)$ soru-cevap, 19'u $(\% 15,97)$ boşluk doldurmalı maddeler, 9'u $(\% 7,56)$ doğru-yanlış maddeleri, 9'u (\%7,56) ödev, 8'i $(\% 6,72)$ deneme sınavı, 8'i $(\% 6,72)$ açık uçlu sorular, 6'sı $(\% 5,04)$ yazılı ürün değerlendirme, 3’ü $(\% 2,52)$ eşleştirme, 3’ü $(\% 2,52)$ kontrol listeleri, 2'si $(\% 1,68)$ okumayı değerlendirme, 2'si $(\% 1,68)$ Konuşma performansı değerlendirme, 1’i (\%o,84) Kelime havuzundan seçerek anlamlı cümle kurma, 1’i $(\% 0,84)$ dikte, 1’i $(\% 0,84)$ kısa cevaplı sorular, 1’i $(\% 0,84)$ bulmaca, 1’i $(\% 0,84)$ öğrenci ürün dosyası, 1’i $(\% 0,84)$ süreç odaklı değerlendirme tekniklerini kullandığını belirtmiştir.

Tablo 13 incelendiğinde katılımclların 23’ü $(\% 19,33)$ uzaktan yabancılara Türkçe öğretimi sürecinde ölçme ve değerlendirme teknikleri arasında sıklıkla çoktan seçmeli test tekniğini kullandığını belirtmiştir.

K17: Çoktan seçmeli sorular.

K21: Öğrenciler ile çoktan seçmeli sorular üzerinden çalşmalar yaptık. Pratik olduğu ve zaman tasarrufu sağladiğı için.

Tablo 13 incelendiğinde katılımcıların 21’i $(\% 17,65)$ uzaktan yabancılara Türkçe öğretimi sürecinde ölçme ve değerlendirme teknikleri arasında sıklıkla soru-cevap tekniğini kullandığını belirtmiştir.

K2: Bu konuda birçok alternatiflerimiz var KAHOOT üzerinde oluşturduğumuz soru cevap quizleri.

\section{K15: En çok kullandiğımız teknikleri soru-cevap tekniği}

Tablo 13 incelendiğinde katılımcıların 19’u $(\% 15,97)$ uzaktan yabancılara Türkçe öğretimi sürecinde ölçme ve değerlendirme teknikleri arasında sıklıkla boşluk doldurma tekniğini kullandığını belirtmiştir.

\section{K18: Boşluk doldurma.}

\section{K2O: Boşluk doldurmalı maddeler}

Tablo 13 incelendiğinde katılımcıların 9'u $(\% 7,56)$ uzaktan yabancılara Türkçe öğretimi sürecinde ölçme ve değerlendirme teknikleri arasında sıklıkla doğru-yanlış maddeli test tekniğini kullandığını belirtmiştir.

\section{K25: Doğru/yanlış.}

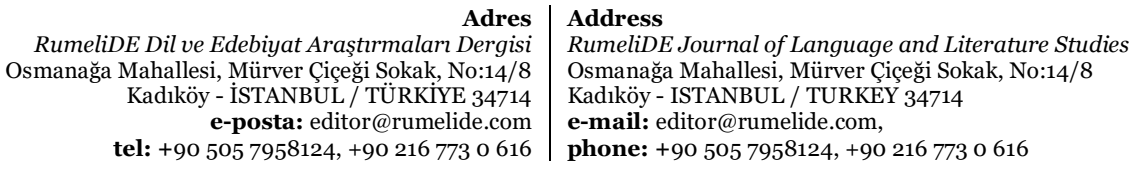


K38: Doğru yanlış soruları.

Tablo 13 incelendiğinde katılımcıların 9’u $(\% 7,56)$ uzaktan yabancllara Türkçe öğretimi sürecinde ölçme ve değerlendirme teknikleri arasında sıklıkla ev ödevlerini kullandığını belirtmiştir.

Kıo: En önemli takip ödevler. Her hafta düzenli ödev veriyoruz.

K31: Ödevler (yazma ödevi, konuşma videosu)

Tablo 13 incelendiğinde katılımcıların 8’i $(\% 6,72)$ uzaktan yabancılara Türkçe öğretimi sürecinde ölçme ve değerlendirmede sıklıkla deneme sınavlarını kullandığını belirtmiştir.

Kı: Online deneme sinavı yapıyoruz. Birçok soru tipini içeriyor bu sınavlar.

K12: Çevrimiçi deneme sınavı yapıyoruz. Her soru tipi var. Bu dönem A1 sinavın yüz yüze yaptık, diğer sinavları yine çevrimiçi yapacă̆ız.

Tablo 13 incelendiğinde katılımclların 8’i $(\% 6,72)$ uzaktan yabancılara Türkçe öğretimi sürecinde ölçme ve değerlendirmede sıklıkla açık uçlu soruları kullandığını belirtmiştir.

K19: Açlk uçlu sorular.

K24: ... ve açık uçlu sorularm yer aldığı çalışma kâğıtlarıyla süreci yürütüyorum.

Tablo 13 incelendiğinde katılımcıların 6'sı $(\% 5,04)$ uzaktan yabancılara Türkçe öğretimi sürecinde ölçme ve değerlendirmede sıklıkla yazılı ürün değerlendirmeyi kullandığını belirtmiştir.

K7: Öğrencilerin gelişimlerini daha çok kısa ve uzun yazma çahışmalarında gözlemlemeye çalışıyorum.

K40: Öğrencilere yazı yazdırılı ders ortamında paylaştırılması.

Tablo 13 incelendiğinde katılımcıların 3’ü $(\% 2,52)$ uzaktan yabancılara Türkçe öğretimi sürecinde ölçme ve değerlendirme teknikleri arasında sıklıkla eşleştirme maddeli test tekniğini kullandığını belirtmiştir.

K23: Eşleştirme.

K24: Eşleştirme.

Tablo 13 incelendiğinde katılımcıların 3’ü $(\% 2,52)$ uzaktan yabancılara Türkçe öğretimi sürecinde ölçme ve değerlendirme teknikleri arasında sıklıkla kontrol listelerini kullandığını belirtmiştir.

K25: Var-yok gibi etkinlikler

K26: En çok kullandığımız ... var-yok test maddeleri ...

Tablo 13 incelendiğinde katılımcıların 2'si $(\% 1,68)$ uzaktan yabancllara Türkçe öğretimi sürecinde ölçme ve değerlendirmede sıklıkla okuduğunu anlamayı değerlendirdiğini belirtmiştir.

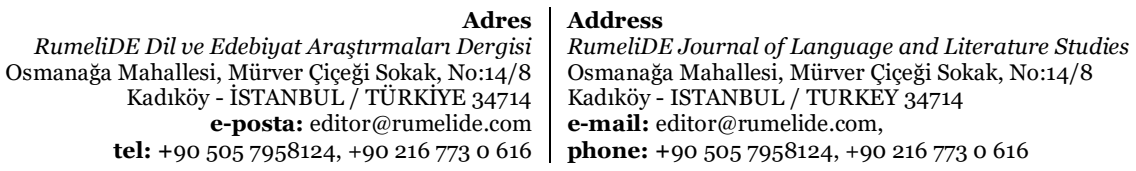


K23: Paragrafözetleme.

K40: Okuma-anlama.

Tablo 13 incelendiğinde katılımcıların 2'si $(\% 1,68)$ uzaktan yabancılara Türkçe öğretimi sürecinde ölçme ve değerlendirmede sıklıkla konuşma performansı değerlendirdiğini belirtmiştir.

K27: Ben her zaman öğrencileri konuşturarak öğrencilerin bilgisini ölçmeye çalş̧tım ve çalışırım.

Tablo 13 incelendiğinde katılımcıların 1’i $(\% o, 84)$ uzaktan yabancılara Türkçe öğretimi sürecinde ölçme ve değerlendirmede sıklıkla kelime havuzundan seçerek anlamlı cümle kurma tekniğini kullandığını belirtmiştir.

K19: Karışık kelimelerden anlaml ve kurall cümle kurma vb. ölçme ve değerlendirme teknikleridir.

Tablo 13 incelendiğinde katılımclların 1’i $(\% 0,84)$ uzaktan yabancllara Türkçe öğretimi sürecinde ölçme ve değerlendirmede sıklıkla dikte yöntemini kullandığını belirtmiştir.

K4O: Dikte ve verilen dikteye bağh etkinlikler

Tablo 13 incelendiğinde katılımcıların 1’i $(\% 0,84)$ uzaktan yabancılara Türkçe öğretimi sürecinde ölçme ve değerlendirmede sıklıkla kısa cevaplı maddeleri kullandığını belirtmiştir.

K38: Kısa cevaph yazılı yoklama

Tablo 13 incelendiğinde katılımclların 1’i $(\% 0,84)$ uzaktan yabancllara Türkçe öğretimi sürecinde ölçme ve değerlendirmede sıklıkla bulmaca kullandığını belirtmiştir.

\section{K36: Kendi hazırladı̆̆m bulmaca ve etkinlikler}

Tablo 13 incelendiğinde katılımclların 1’i $(\% 0,84)$ uzaktan yabancllara Türkçe öğretimi sürecinde ölçme ve değerlendirmede sıklıkla ürün dosyası kullandığını belirtmiştir.

K2o: Ürün dosyasl.

Tablo 13 incelendiğinde katılımclların 1’i $(\% 0,84)$ uzaktan yabancllara Türkçe öğretimi sürecinde ölçme ve değerlendirmede sıklıkla süreç odaklı değerlendirme kullandığını belirtmiştir.

K33: Bizim uzaktan sistemimiz derslerin kaydedilmesini sağhyor. Daha sonra bu kayıtları izleyerek öğrencinin süreç içindeki gelişimini izlemek oldukça kullanışl bir yöntem.

\subsection{Uzaktan yabancılara Türkçe öğretiminin avantajlarına ilişkin bulgular}

Katılımcıların “Uzaktan eğitimin yabancı dil olarak Türkçe öğretimine sunduğu avantajlar nelerdir?” sorusuna ilişkin verdikleri yanıtlardan elde edilen bulgular Tablo 14’te gösterilmektedir.

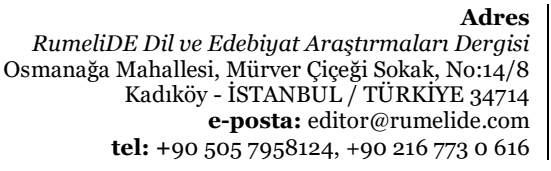

Adres

RumeliDE Journal of Language and Literature Studies

Osmanağa Mahallesi, Mürver Çiçeği Sokak, No:14/8

Kadıköy - ISTANBUL / TURKEY 34714

e-mail: editor@rumelide.com,

phone: +90 $5057958124,+902167730616$ 


\begin{tabular}{|c|c|c|c|c|c|}
\hline Kodlar & $\mathrm{f}$ & $\%$ & Kodlar & $\mathrm{f}$ & $\%$ \\
\hline \multirow[t]{4}{*}{ Ekonomik } & \multirow{4}{*}{47} & \multirow{4}{*}{51,65} & Mekân & 22 & 46,8 \\
\hline & & & Para & 11 & 23,40 \\
\hline & & & Zaman & 7 & 14,89 \\
\hline & & & Mesafe & 7 & 14,89 \\
\hline Bilgiye erişimin kolay olması & 9 & 9,89 & & & \\
\hline Avantajı yok & 7 & 7,69 & & & \\
\hline Dersi tekrar izleme & 6 & 6,59 & & & \\
\hline Çeşitli materyal oluşturma & 5 & 5,49 & & & \\
\hline Konforlu & 4 & 4,40 & & & \\
\hline Ulaşılır olma & 4 & 4,40 & & & \\
\hline Teknolojiden yararlanma bilincinin yerleşmesi & 3 & 3,30 & & & \\
\hline Zaman esnekliği & 3 & 3,30 & & & \\
\hline Ödev kontrolü ve dönütlerin kolaylaşması & 2 & 2,20 & & & \\
\hline Öğrencinin kolaylıkla sertifika alması & 1 & 1,10 & & & \\
\hline TOPLAM & 91 & 100,00 & & & \\
\hline
\end{tabular}

Tablo 14 incelendiğinde katılımcıların 47'si $(\% 51,65)$ uzaktan yabancılara Türkçe öğretiminin ekonomik açıdan avantajlı olduğunu belirtmiştir. Bu avantajların ise mekân ( $\mathrm{n}=22, \%=46,8)$, para $(\mathrm{n}=11, \%=23,4)$, zaman $(n=7, \%=14,89)$ ve mesafe $(n=7, \%=14,89)$ açısından işlendiği görülmüştür. Tablo 14 incelendiğinde katılımcıların uzaktan yabancılara Türkçe öğretiminin avantajları arasında 9'u (\%9,89) bilgiye erişimin kolay olduğunu, 6’sı $(\% 6,59)$ dersin tekrar izlendiğini, 5’i $(\% 5,49)$ çeşitli materyal oluşturulduğunu, 4’ü (\%4,40) konforlu olduğunu, 4’ü $(\% 4,40)$ ulaşllır olduğunu, 3’ü $(\% 3,30)$ teknolojiden yararlanma bilincinin yerleştiğini, 3’ü (\%3,30) zaman esnekliği sağlandığını, 2'si (\%2,20) ödev kontrolü ve dönütlerin kolaylaştığını, 1’i $(\% 1,10)$ Öğrencinin kolaylıkla sertifika aldığını belirtmiştir. Katılımcıların 7'si $(\% 7,69)$ ise uzaktan yabancılara Türkçe öğretiminin herhangi bir avantajının olmadığını belirtmiştir.

Tablo 14 incelendiğinde katılımcıların 47'sinin $(\% 51,65)$ uzaktan yabancılara Türkçe öğretiminin ekonomik olduğunu; bunu ise mekân $(n=22, \%=46,8)$, para $(n=11, \%=23,4)$, zaman $(n=7, \%=14,89)$ ve mesafe $(n=7, \%=14,89)$ açısından avantaj getirdiğini belirtmişlerdir. Mekân özgürlüğünü ekonomik açıdan değerlendiren katılımcı görüşleri şöyledir.

K1o: Mekân kısıtlamasinı ortadan kaldırması avantaj bence.

\section{K17: Mekân rahathı̆ı.}

K32: Ancak uzaktan öğretim, ebeveyn ve çalşan öğrenciler için bir avantaj sağladı. Derslere bulundukları yerlerden katılma firsatı buldular.

Tablo 14 incelendiğinde katılımclların 11’i $(\%=23,4)$ uzaktan yabancılara Türkçe öğretiminin maddi açıdan ekonomik olduğunu belirtmiştir.

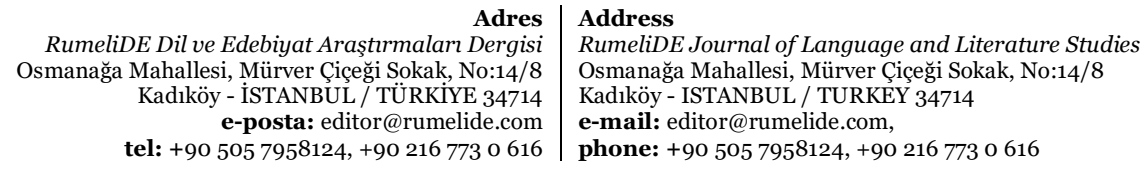


K1o: Yurt dışında Türkçe öğrenmek için bu tarz bir online eğitim oldukça ucuza gelir. Birçok yaşam giderinden kurtulmuş olursun.

K23: Toplam maliyeti azaltmasl.

Tablo 14 incelendiğinde katılımclların 7'si $(\%=14,89)$ uzaktan yabancılara Türkçe öğretiminin zaman tasarrufu sağlaması açısından ekonomik olduğunu belirtmiştir.

K2: Derse katılmak için harcanan zaman israfinı önlemesi en büyük avantajlar arasında.

K39: Zaman konusunda avantajl olabilirler.

Tablo 14 incelendiğinde katılımclların 7’si $(\%=14,89)$ uzaktan yabancllara Türkçe öğretiminin mesafe açısından ekonomik olduğunu belirtmiştir.

K2: Mesafeyi ortadan kaldırması.

K25: Öğrenciler için de kendi ülkelerinden de eğitime katılabilmeleri.

Tablo 14 incelendiğinde katılımcıların 9’u (\%9,89), uzaktan yabancılara Türkçe öğretiminin avantajları arasında bilgiye erişimin kolay olduğunu belirtmiştir.

K9: Bunun dışında uzaktan eğitimde bilgiye ulaşma kolaylı̆̆ (hem öğrenci hem de öğretmen için) sistemin avantajları arasindadir.

K24: Bilgiye erişimi daha kolaydır.

Tablo 14 incelendiğinde katılımcıların 6’sı $(\% 6,59)$, uzaktan yabancılara Türkçe öğretiminin avantajları arasında dersi tekrar izleme olduğunu belirtmiş̦tir.

K5: Dersin kayıt altına alınması, ... sanırm en büyük avantajları. Okulda, bir ders anlatıldı̆̆ında, öğrenci o gün gelmediyse, önceki derse ilişkin kısaca bilgi veriliyordu. Ancak şu an öğrenci derse gelmezse de dersi kayıtlardan izleyip hızl bir şekilde ertesi günün konusuna yetişebiliyor.

K15: Öğrenci açısında tek avantajı, ders kayıtları sayesinde anlamadığı dersleri tekrar tekrar izleme imkanına sahip olmasıdır diyebiliriz.

Tablo 14 incelendiğinde katılımcıların 5’i $(\% 5,49)$, uzaktan yabancılara Türkçe öğretiminin avantajları arasında çeşitli materyal oluşturma olduğunu belirtmiştir.

K16: Ciddi bir eksiğimiz materyal konusunda kendi eksiklerimi nispeten tamamladığımı düşünüyorum. Materyal oluşturmada çeşitlilik kattığımızı da atlamayahm.

K23: Ders esnasında anlık farkh materyaller kullanmaya elverişli olması.

Tablo 14 incelendiğinde katılımcıların 4'ü $(\% 4,40)$ uzaktan yabancılara Türkçe öğretiminin konfor açısından avantajlı olduğunu belirtmiştir.

K24: Kıyafetten bağımsızdır. Öğrenci fiziki olarak daha rahattır.

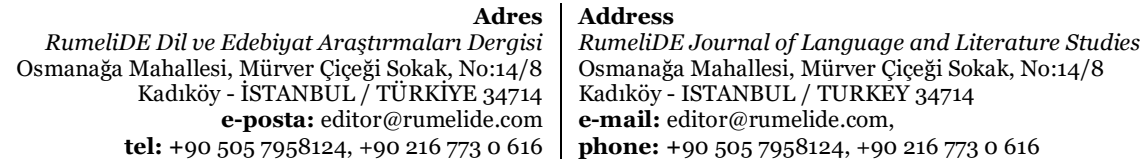


K33: Uzaktan öğretim daha rahat bir öğrenme süreci sağhyor. Ben bunu olumlu görüyorum. Öğrenciler sinıf ortamında, dersler de art arda iken daha huzursuz olduğunu iddia edebilirim.

Tablo 14 incelendiğinde katılımcıların 4’ü $(\% 4,40)$ uzaktan yabancılara Türkçe öğretiminin ulaşılır olma açısından avantajlı olduğunu belirtmiştir.

K3: Her an her yerde öğrenciye ulaşabildik.

K5: Her an ulaşılabilir olunması sanırım en büyük avantajları.

Tablo 14 incelendiğinde katılımcıların 3’ü $(\% 3,30)$ uzaktan yabancılara Türkçe öğretiminin teknolojiden yararlanma bilincinin yerleşmesi açısından avantajlı olduğunu belirtmiştir.

K14: Ayrıca, eğitimde teknolojizi sımı ortamında kullanmaktan kaçınanlar için zorunlu bir kullanım durumu ortaya çıktığından teknolojiden yararlanma konusunda bir bilinç ortaya çıktığımı düşünüyorum.

K35: Öğreticiler daha çok web araçlarından, bilişim teknolojilerinden yararlanmaya başladı.

Tablo 14 incelendiğinde katılımclların 3’ü (\%3,30) uzaktan yabancllara Türkçe öğretiminin zaman esnekliği açısından avantajlı olduğunu belirtmiştir.

K6: Ders işleniş̧iyle ilgili oluşabilecek esneklik dışında yüz yüzenin yerini tutamaz.

K30: Zaman sinur yok, dersimi istediğim saatte hem kendime göre hem de öğrencilerime göre ayarlayabiliyorum.

Tablo 14 incelendiğinde katılımclların 2'si (\%2,20) uzaktan yabancllara Türkçe öğretiminin ödev kontrolü ve dönütler kolay bir şekilde verilmesi açısından avantajlı olduğunu belirtmiştir.

K33: Yazma becerisinin temel seviyesinde hataların gösterilmesi için çok kullanışl. Örgün öğretimde bu kadar kısa sürede çok öğrenciye dönüt vermem daha zor.

K36: Ödev kontrolü kolaylaşth.

Tablo 14 incelendiğinde katılımclların 1’i $(\% 1,10)$ uzaktan yabancılara Türkçe öğretiminin öğrencinin kolaylıkla sertifika alması açısından avantajlı olduğunu belirtmiştir.

K22: Öğrenciler için sağladı̆̆ı avantaj ise kolaylıkla sertifika sahibi olmaları diyebiliriz. Uzaktan girdikleri sınavlarda sımıf düzeyinde başarısız olan öğrencilerin kur sınavlarında başarılı oldukları görülmüştür.

\subsection{4. Öğreticilerin yabancılara uzaktan Türkçe öğretimi sürecine yönelik öz değerlendirmelerine ilişkin bulgular}

Katılımcıların "Yüz yüze eğitime nazaran uzaktan eğitimde kendinizi nasıl değerlendiriyorsunuz?" sorusuna ilişkin verdikleri yanıtlardan elde edilen bulgular Tablo 15’te gösterilmektedir.

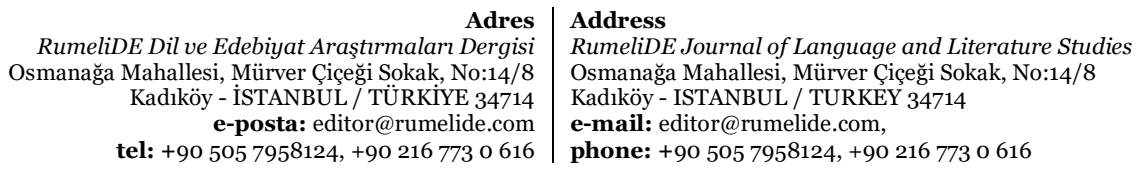




\begin{tabular}{|c|c|c|c|c|c|}
\hline Kodlar & $\mathrm{f}$ & $\%$ & & $\mathrm{f}$ & $\%$ \\
\hline \multirow[t]{8}{*}{ Olumsuz } & \multirow[t]{8}{*}{46} & \multirow[t]{8}{*}{56,79} & Yüz yüze eğitimdeki kadar verimli olamayan biri & 19 & 41,30 \\
\hline & & & Hareketleri kısıtlanmış biri & 11 & 23,91 \\
\hline & & & Yorulan biri & 7 & 15,21 \\
\hline & & & Motivasyonu düşen biri & 3 & 6,52 \\
\hline & & & Fiziksel rahatsızlıklar yaşamaya başlayan biri & 2 & 4,34 \\
\hline & & & Yeterli dönüt veremeyen biri & 2 & 4,34 \\
\hline & & & Bilgisayar karşısında ders anlatmaktan sıkılan biri & 1 & 2,17 \\
\hline & & & Yüz yüze eğitimi özleyen biri & 1 & 2,17 \\
\hline Toplam & & & & 46 & 100 \\
\hline \multirow[t]{7}{*}{ Olumlu } & \multirow[t]{7}{*}{35} & \multirow[t]{7}{*}{43,21} & Eksik yönlerini görme ve geliştirme imkânı bulan biri & 11 & 31,42 \\
\hline & & & Yeterli biri & 8 & 22,85 \\
\hline & & & Özverili biri & 7 & 20 \\
\hline & & & Eğitim teknolojilerini iyi kullanan biri & 4 & 11,42 \\
\hline & & & Uzaktan eğitime olumlu yaklaşmaya başlayan biri & 3 & 8,57 \\
\hline & & & Yeterli dönüt verebilen biri & 1 & 2,85 \\
\hline & & & Uzaktan eğitimden keyif alan biri & 1 & 2,85 \\
\hline Toplam & & & & 35 & 100 \\
\hline
\end{tabular}

Tablo 15 incelendiğinde katılımcıların 46'sı $(\% 56,79)$ uzaktan yabancılara Türkçe öğretiminde kendilerini olumsuz yönde değerlendirmiştir. Bunların 19'u (\%41,30) yüz yüze eğitimdeki kadar verimli olamayan, 11’i $(\% 23,91)$ hareketleri kısıtlanmış, 7’si $(\% 15,21)$ yorulan, 3’ü $(\% 6,52)$ motivasyonu düşük, 2'si $(\% 4,34)$ fiziksel rahatsızlıklar yaşamaya başlayan, 2'si $(\% 4,34)$ yeterli dönüt veremeyen, 1’i $(\% 2,17)$ bilgisayar karşısında ders anlatmaktan sıkılan, 1 ’’ $(\% 2,17)$ yüz yüze eğitimi özleyen biri olarak kendilerini değerlendirmiştir.

Tablo 15 incelendiğinde katılımcıların 19’u (\%41,30), kendilerini yüz yüze eğitimdeki kadar verimli olamadıkları şeklinde değerlendirmiştir.

K15: Ancak her ne olursa olsun yüz yüze eğitimde göstermiş olduğumuz performansı (uzaktan eğitimde çok daha fazla yorulsak da) uzaktan eğitimde yansıtamıyoruz.

K17: Yüz yüze eğitimde daha başarılı olduğumu düşünüyorum.

K20: Zorlandığımı düşünüyorum çünkü öğrenci ile göz teması kuramadığım için anlayıp anlamadiğımı anlayamıyorum.

K21: Performansim \%5o azald.

Tablo 15 incelendiğinde katılımcıların 11’i (\%23,91), kendilerini hareketleri kısıtlanan biri olarak değerlendirmiştir.

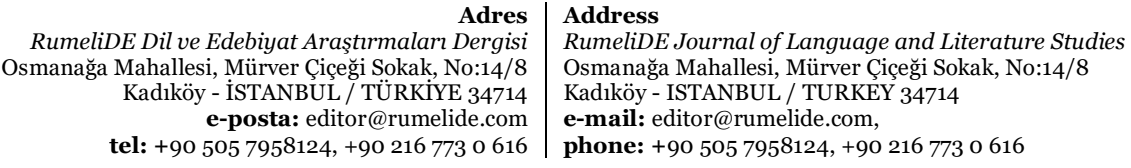


K14: Ayrıca yabancı dil öğretiminin önemli bir parçası olan beden dilini kullanamamak da oldukça zorluyor.

K5: Yüz yüze eğitimde bir işin, nesnenin ne demek olduğu ya da bir fiilin ne anlama geldiği sorulduğunda vücut, jest ve mimiklerle sorularm sorunun cevabını verir, bir çeşit "drama" yapardım. Ancak uzaktan öğretimde, küçük bir kamera karşısında bunları yapmak zor olmaktadır. Bir sözcüğün anlamı sorulduğunda ya da bir nesnenin ne olduğu sorulduğunda, -görselleştirilebilir bir şeyseGoogle arama motorundan görselle göstermekteyim. Bu yöntem, öğrenilen sözcüğün kahcı olmasın zorlaştırmaktadır.

K16: Ve tabi ki dil öğretiminde en önemli materyal öğreticinin bedenidir. Tiyatral özellikleri istediğim gibi yansıtamıyorum. Elimi kaldırsam kolum görünmüyor. Kolumu kaldırsam elim görünmüyor.

Tablo 15 incelendiğinde katılımcıların 7’si (\%15,21), kendilerini yorgun biri olarak değerlendirmiştir.

K1: Sürekli bir yetememe, anlatamama, anlaşllamama kaygısının verdiği öğrenciyi sımıf ortamındaki kadar iyi gözlemleyememenin sebep olduğu anlayamama- anlaşılamama kaygısından ötürü yorgun.

K5: Yüz yüze eğitimde, uzaktan eğitime nazaran daha fazla saat ders yapıyordum ve yorulmuyordum. Uzaktan eğitimde daha az süre eğitim vermeme rağmen, sinıfi aktif tutma çabalarımdan dolayı oldukça yoruluyorum. Başarıyorum, simıfi aktif tutuyorum ama uzaktan eğitimde bu iş daha zor ve yorucu oluyor.

K13: Devaml ekrana bakmaktan gözlerim çok yoruluyor. Uzaktan eğitimin sımf ortamından daha fazla yorduğu kanaatindeyim.

K3o: Öğretmen açısından çok fazla hazırlık gerektirdiğinden yorucu.

Tablo 15 incelendiğinde katılımcıların 3’ü $(\% 6,52)$, kendilerini motivasyonu düşük biri olarak değerlendirmiştir.

K21: Motivasyonum düş̧ü.

K23: Uzaktan eğitimde öğrenciler ile etkileşimin yüz yüze eğitimdeki gibi olmaması motivasyonu etkileyebilmektedir.

Tablo 15 incelendiğinde katılımcıların 2'si $(\% 4,34)$, kendilerini fiziksel rahatsızlıklar yaşamaya başlayan biri olarak değerlendirmiştir.

K16: Tek sıkıntım sürekli oturarak ekran karşısına hitap etmekten kaynaklanan fiziksel rahatsızhklar, bel boyun ağrısı, bilgisayar ışığına sürekli maruz kalınca gözlerde problemler.

Tablo 15 incelendiğinde katılımclların 2'si $(\% 4,34)$, kendilerini yeterli dönüt veremeyen biri olarak değerlendirmiştir.

K5: Öğrenci ödevlerini takip etme konusunda kendimi yetersiz buluyorum. Yüz yüze eğitimde öğrenci ödevlerine sağlıkl dönüşler yapabiliyorken, uzaktan eğitimde çok sağhlkh dönüşler yapmadığımı düşünüyorum.

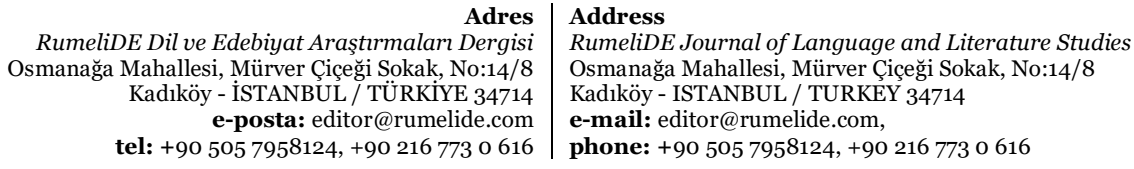


Tablo 15 incelendiğinde katılımclların 1’i (\%2,17), bilgisayar karşısında ders anlatmaktan sıkılan biri olarak değerlendirmiştir.

K1o: Kendi başına bilgisayar önünde ders anlatmak bazen sıkıcı.

Tablo 15 incelendiğinde katılımclların 1’i (\%2,17), kendisini yüz yüze eğitimi özleyen biri olarak değerlendirmiştir.

K12: Ancak yüz yüze eğitimi inanılmaz özlüyorum.

Tablo 15 incelendiğinde katılımcıların 35’i $(\% 31,42)$ uzaktan yabancılara Türkçe öğretiminde kendilerini olumlu yönde değerlendirmiştir. Bunların 11’i (\%41,30) eksik yönlerini görme ve geliştirme imkânı bulan, 8’i $(\% 22,85)$ yeterli, 7’si (\%20) özverili, 4’ü $(\% 11,42)$ eğitim teknolojilerini iyi kullanan, 3’ü $(\% 8,57)$ uzaktan eğitime olumlu yaklaşmaya başlayan, 1 ’i $(\% 2,85)$ yeterli dönüt verebilen, 1’i $(\% 2,85)$ uzaktan eğitimden keyif alan biri olarak kendilerini değerlendirmiştir.

Tablo 15 incelendiğinde katılımcıların 11’i $(\% 41,30)$ kendilerini eksik yönlerini görme ve geliştirme imkânı bulan biri olarak değerlendirmiştir.

K17: Kendimi geliştiriyorum. Ama hâlen dijital dönüşüme vakit var diye düşünüyorum.

K18: İnternet ortamındaki akademik yazın, materyalleri keșfetme firsatı buldum. Uzaktan eğitim gerçekleştirilen uygulamalar fazlaca öğrendim. Dijitalleşme ile ilgili ciddi bir birikim edindim. Temel seviyelerde zorlanyoruz ancak ileri seviyelerde mesela C1, akademik Türkçe gibi eğitimlerde uzaktan eğitime devam edilebileceğini düşündüm. Materyal hazırlarken ofis programlarn hâkimiyetim daha da gelişti.

K22: Önceleri sisteme alışmakta zorlandiğımı, ancak kullana kullana ahıştı̆ımı düşünüyorum. Dijital içerik geliştirmede kendimi geliştirdiğimi söyleyebilirim. Özellikle dijital tablet kullanımı pek çok yönden işimi kolaylaştırmıştır. Sinıfta tahta kullanır gibi kalem kullanarak söylediklerimizi öğrenciye aktarma süreci paha biçilemez. Ancak bu durum uzaktan eğitim sürecinin ikinci yarısında başlamıştır. İlk zamanlar her öğretmen gibi zorlandığımı düşünüyorum.

K41: Kendimizi teknolojik açıdan geliştirdik. Duruma alş̧tı. Ders işleyişini uzaktan öğretime göre ayarlamaya çalıştı.

Tablo 15 incelendiğinde katılımclların 8’i $(\% 22,85)$ kendilerini yeterli biri olarak değerlendirmiştir.

K23: Yüz yüze eğitimde her simıfta akull tahta olmaması derste benimsenen yaklaşım, yöntem gibi unsurları sekteye uğratabiliyordu. Eklektik yaklaşım bağlamında öğrenen ve öğretici için ortak ekran ve dönüt verme süresi benim için büyük avantaj. Tahta kullanımı için grafik tablet kullamılmakta. Bu manada teknolojik yeterliliğe sahip olduğumu düşünüyorum.

K43: Bu tamamen benim fikrim Türkçe öğrenmek isteyen ve çalışan öğrencilere fazlasıyla çalışmalarım yetiyor. Ama genel değerlendirecek olursam ben elimden geleni fazlasıyla yaptığımı düşünüyorum.

Tablo 15 incelendiğinde katılımcıların 7’si (\%20) kendilerini özverili biri olarak değerlendirmiştir.

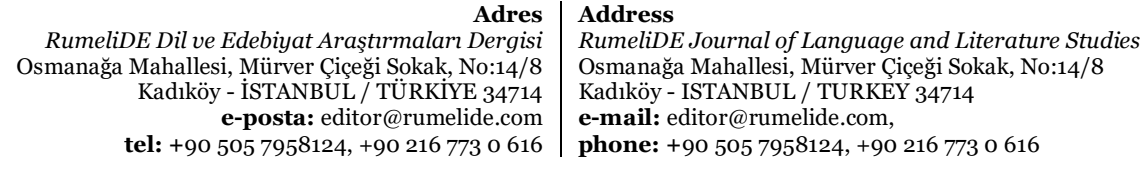


K22: Ancak bu süreci elimden geldiğince olumlu atlatmaya, Türkçeyi olabildiğince iyi öğretmeye çalışmaktayım.

K25: Yüz yüze eğitimde olduğu gibi uzaktan eğitimde de elimden gelenin en iyisini yapmaya çalışıyorum.

K19: Uzaktan eğitime göre kendimin daha özverili çalıştığını düşünmekteyim. Çünkü uzaktan eğitimde anahtar ögenin öğretmen olduğunu düşünmekteyim.

K34: Yüz yüze eğitimde yabancı öğrencilerimize nasıl öğretici, koruyucu ve saygıh yaklaştıysam çevrim içi mecralarda da yine aynı şekilde hatta daha yoğun çabalar sarf ederek öğrencilerimizin bu salgin psikolojisinden en az düzeyde etkilemesi hatta hiç etkilenmemesi için Türkçe öğretmenliğinin yanı sıra bir psikolog gibi de çalıştım.

Tablo 15 incelendiğinde katılımclların 4’ü $(\% 11,42)$ kendilerini eğitim teknolojilerini iyi kullanan biri olarak değerlendirmiştir.

K5: Bilgisayar kullanma, telefon kullanma konularında oldukça yetkinimdir. Teknolojik gelişmeleri takip eden, sorgulayan ve kullanan biri olduğumdan uzaktan eğitimde bu anlamda hiç zorlanmadım. Yüz yüze eğitimde teknolojik materyalleri bu kadar kullanmıyordum.

K23: Bu manada teknolojik yeterliliğe sahip olduğumu düşünüyorum.

K12: Pek çok web2 aracı biliyor ve zaman zaman kullanıorum. Teknik anlamda hiç sıkıntı yaşamadım.

Tablo 15 incelendiğinde katılımcıların 3’ü $(\% 8,57)$ kendilerini uzaktan eğitime olumlu yaklaşmaya başlayan biri olarak değerlendirmiştir.

K5: Uzaktan eğitime ilk geçtiğimizde kameraya bakarak konuşmak motivasyonumu düşürmüştü. Alş̧ma sürecini atlattıktan sonra, bu tutumum da değişti.

K8: Illk başta nasıl olacak endişesini taşıyordum ama zaman içerisinde uzaktan da yapabileceğimi gördüm.

K19: Salginla birlikte uzaktan eğitim modeli tecrübesi kazandım. Olumlu ya da olumsuz büyük bir tecrübe kattı̆ııı düşünmekteyim. Özellikle B1, B2 ve C1 düzeylerinde uzaktan eğitim modeline sıcak bakmaya başladım. Daha önce böyle bir düşüncem yoktu.

Tablo 15 incelendiğinde katılımcıların 1’i $(\% 2,85)$ kendisini yeterli dönüt verebilen biri olarak değerlendirmiş̧ir.

K1o: Ödevlere etkili dönütler verebiliyorum.

Tablo 15 incelendiğinde katılımcıların 1’i $(\% 2,85)$ kendisini uzaktan eğitimden keyif alan biri olarak değerlendirmiştir.

K16: Her zaman mesleğimi icra etmekten keyif aldım. Şimdi de oldukça keyif alıyorum.

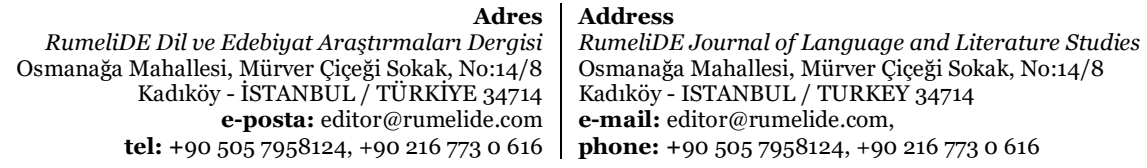




\section{Tartışma, sonuç ve öneriler}

Dili kullanma fırsatı hem bilişsel hem de duyuşsal olarak yabancı dil öğrenme sürecine büyük avantajlar sunmaktadır. Dili kullanma firsatı bulanlar dile ait ögelerin ne olduğunu öğrenmek ile birlikte sosyokültürel çevre içinde bu bağlamın nasıl kullanıldığını da deneyimler. Doğrudan yaşantılarla ilişkili olduğu için bu deneyimler bilginin daha iyi depolanmasını ve öğrenenlere hedef dilde birtakım duyuşsal izler bırakmasını sağlar. Böylece yabancı dile ait her bir öge, öğrenen için anlamlı, deneyime dayalı, canlı bir işleve sahip olur. Bu bakımdan yüz yüze eğitim şekli Türkçenin yabancı dil olarak öğretiminde sınıf dışında da yoğun etkileşimsel çevre olanakları sunmaktadır. Dil öğretenlerin yüz yüze eğitim şeklinin sunduğu olanaklarla öğretim metotlarını çeşitlendirmesi, sözlü dilin yanı sıra beden dilinin avantajlarını kullanması; öğrencilerin ise hem öğretmenleriyle hem sınıf arkadaşlarıyla hem de hedef dil konuşurlarıyla etkileşime girerek öğrenme çevresi oluşturması yüz yüze eğitim şeklinin en önemli avantajları arasında görülmektedir. Ancak COVID-19 Pandemi sürecinde toplum sağlı̆̆ını kontrol altına alabilmek için eğitim alanındaki çalışmaların uzaktan eğitim ile sürdürülmesi Türkçenin yabancı dil olarak öğretiminde koşulların da değişmesine neden olmuştur. Bu değişiklik neticesinde öğretmenöğrenci, öğrenci-öğrenci etkileşim yoğunluğunun, öğrencilerin derslere katılımının, öğrenimi güçleşen dil becerilerinin, öğretimi güçleşen dil seviyelerinin, genel öğrenci sayllarının, öğrenci motivasyonlarının, sınavlarda yaşanan sorunların, uygulanan ölçme ve değerlendirme tekniklerinin, öğretici öz değerlendirmelerinin, karşılaşılan sorunların ve avantajların uzaktan yabancılara Türkçe öğretiminde neler olduğunu ortaya koymak önem arz etmiştir. Bu nedenle araştırmada uzaktan eğitimde Türkçenin yabancı dil olarak öğretim sürecini incelemek amaçlanmıştır.

Araştırmada, uzaktan yabancılara Türkçe öğretim sürecinde öğretmenler ile öğrenciler arasında etkileşimin azaldığı; bunun sebebinin de öğrencilerin ders sırasında kamera ve ses aygitlarını açmamaları, etkileşim sürecinde önemli olan göz teması ve beden hareketlerini kullanamamaları olduğu belirtilmiştir. Özellikle yeni kaydolan öğrenciler ile öğretmenlerin birbirleriyle tam olarak etkileşime geçemedikleri belirtilmiştir. Birişçi (2013) de öğrencilerin video konferans sisteminde yaşanan teknik problemlere bağlı olarak ders anlatımları sürecinde öğretici-öğrenci arasında etkili iletişimin kurulamadığını ve öğreticiyle yüz yüze ortamda bulunmama ve derse motive olamama şeklinde birtakım olumsuz düşünce içerisinde olduklarını belirlemiştir. Güngör, Çangal ve Demir (2020) ise uzaktan yabancılara Türkçe öğretiminin olumsuz yönleri arasında öğreticilerin sınırlı etkileşime değindiklerini belirtmişlerdir.

Öğretmen-öğrenci etkileşiminin olumlu olarak etkilendiğini belirten az sayıda $(n=4, \% 8,88)$ görüş belirtilmiştir. Bulgulara göre, ders dışında gelişen mesajlaşma ve konuşmaya yönelik paylaşımlar öğretmenler ile öğrenciler arasındaki etkileşimi olumlu yönde etkilemiştir.

Uzaktan yabancllara Türkçe öğretiminde öğrenci-öğrenci etkileşimine ilişkin olumlu bir görüşün belirtilmemiş olması dikkat çekmektedir. Elde edilen sonuçlar, uzaktan eğitim sürecinde öğrencilerin birbirinden öğrenme deneyimlerini sınırlandırdığını ve sosyal ilişki içinde dili kullanmalarını kısıtladığını ortaya çıkarmıştır.

Öğrenci-öğrenci etkileşiminin uzaktan yabancılara Türkçe öğretiminde olumsuz yönde etkilendiği ( $\mathrm{f}=30$, \%100) tespit edilmiştir. Bulgulara göre, öğrencilerin yüz yüze eğitimde kurdukları sınıf içi yardımlaşma ve samimi iletişim kurma olanakları uzaktan yabancılara Türkçe öğretiminde azalmıştır.

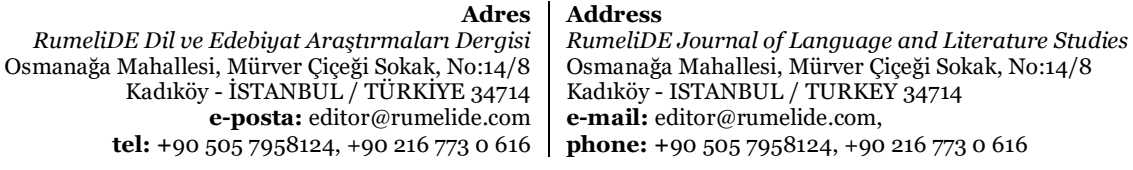


Uzaktan yabancllara Türkçe öğretimi sürecinde olumsuz yönde değişen öğretmen-öğrenci, öğrenciöğrenci etkileşimini, uygun bir seviyeye taşımak için öğreticilerin çeşitli yöntem, teknik ve etkinliklere başvurdukları tespit edilmiştir. Bunların içinde en çok sosyal medya ( $\mathrm{f}=15, \% 28,30)$ kanallarına başvurdukları ve akran danışmanlığı ( $\mathrm{f}=6, \% 11,32)$, dil partnerliği $(\mathrm{f}=6, \% 11,32)$, çevrim içi etkinlikler $(\mathrm{f}=6, \% 11,32)$ ve konuşma kulüpleri $(\mathrm{f}=5, \% 9,43)$ gibi yöntem, teknik ve etkinliklerden faydalanıldı $\mathrm{g}$ belirlenmiştir.

Araştırmada, uzaktan yabancılara Türkçe öğretiminin ortaya koyduğu koşullar gereği programda bazı değişikliklere gidildiği tespit edilmiştir. Bunlar; teknolojik materyal kullanımının artması ( $\mathrm{f}=\mathbf{2 2}$, \%27,50), ders saatinin azalması ( $\mathrm{f}=20, \% 25,00)$, etkinliklerin değiştirilmesi $(\mathrm{f}=13, \% 16,25)$, dijital kitapların kullanılması ( $\mathrm{f}=8, \% 16,25)$, konulara ayrılan sürenin artması ( $\mathrm{f}=5, \% 10,00)$, öğretime ayrılan sürede değişiklik ( $\mathrm{f}=5, \% 6,25)$, teneffüs süresinin değişmesi $(\mathrm{f}=3, \% 3,75)$ ev ödevlerinde değişiklikler $(\mathrm{f}=1, \% 1,25)$, öğretim içeriğinde ve kazanımlarda değişiklik ( $\mathrm{f}=1, \% 1,25)$, kur saatlerinin düzenlenmesi $(\mathrm{f}=1, \% 1,25)$, ders saatlerinde esnek yaklaşım $(\mathrm{f}=1, \% 1,25)$ olarak belirtilmiştir.

Öğreticiler, yüz yüze eğitimde teknoloji tabanlı materyalleri yerine göre kullandıklarını ancak uzaktan yabancılara Türkçe öğretiminde bunun vazgeçilmez bir unsur hâline geldiğini belirterek program içeriğini tamamen teknolojik materyallerle verdiklerini vurgulamışlardır. Araştırmada belirlenen diğer önemli bir değişiklik ders saatlerinin azaltılmasıdır. Ders saatlerindeki azalmanın nedeni olarak öğretim yönetim sistemleri, öğrencilerin kullandıkları araçlar ve öğrencilerin dikkat süreleri gösterilmiştir.

Uzaktan yabancılara Türkçe öğretimi programında belirtilen diğer bir değişiklik ise ders etkinlikleridir. Öğreticiler, yaşadıkları teknik ve etik sorunlardan dolayı dinleme ve yazma becerilerine dönük etkinlikleri tam olarak gerçekleştiremediklerini; bunu telafi etmek için video ve kısa filmleri daha etkili kullandıklarını; öğrencileri derste tutabilmek için etkinliklerin eğlenceli olmasına dikkat ettiklerini ve öğrencilerin ders dışı zamanlarda da Türkçe öğrenmeye devam edebilmeleri için sosyal medya gruplarından çeşitli dosya ve etkinlikleri öğrencilerle paylaştıklarını belirtmişlerdir. Bu değişikliklerin uzaktan eğitimde kullanılan dijital içeriklere ve kısıtlı zaman dilimine ve öğrencilerin etkinliklere etkili katılım sağlamamasına bağlı olarak ortaya çıktığı belirtilmiştir.

Uzaktan yabancılara Türkçe öğretiminde kullanılan kitap şeklinin de değiştiği tespit edilmiştir. Öğreticiler, bu süreçte Yunus Emre Enstitüsünün ve İstanbul Üniversitesinin dijital (Z) kitaplarını kullanmaya başladıklarını; bunları interaktif kullanmaya elverişli olduğu ve süreci olumlu yönde etkilediği için kullandıklarını belirtmişlerdir.

Araştırmada, öğreticiler, uzaktan yabancılara Türkçe öğretiminde öğrenen sayllarının düştüğünü (n=22, \%42,3), devamsız/kayıt donduran öğrencilerin arttığını ( $\mathrm{n}=13, \% 25)$, öğrenci sayılarının arttığını ( $\mathrm{n}=11$, \%21,1) ve öğrenci sayılarında değişiklik olmadığını $(n=6, \% 11,5)$ belirtmiştir. Uzaktan yabancılara Türkçe öğretiminde öğrenen sayllarının düştüğünü belirten öğreticiler, bunun nedeni olarak öğrencilerin zorlanmalarını, kendi çabalarıyla öğrenebileceklerine dair algılarını ve internet sorunu yaşamalarını göstermiştir.

Öğreticiler uzaktan yabancılara Türkçe öğretiminde devamsı/kayıt donduran öğrenci sayılarının arttığını belirtmiştir. Bu durumun nedeni olarak öğrencilerin pandemi sürecinin bitmesiyle yüz yüze eğitim şeklini alma isteklerini ve öğrencilerin yaşadıkları internet sorunlarını göstermişlerdir.

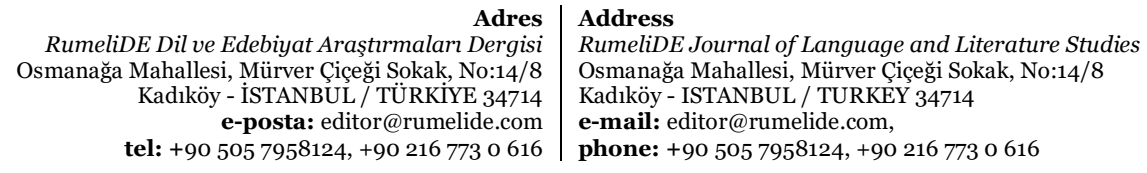


Araştırmada, uzaktan yabancılara Türkçe öğretiminde öğrenen sayısının arttığını bildiren görüşler de yer almıştır. Uzaktan eğitimin şehir dışında ve yurt dışında yaşayanlar için avantaj oluşturduğu, yüz yüze eğitimde başarı yakalayamayan veya zaman ayıramayan öğrencilerin krizi fırsata çevirdikleri ve özellikle ücretli öğrenci sayılarında artış gözlemlendiği belirtilmiştir.

Elde edilen sonuçlar, uzaktan yabancılara Türkçe öğretiminde öğrencilerin derse katılımlarının olumsuz yönde değiştiğini belirtmiştir. Bunun nedenleri olarak öğrencilerin öz disiplin yetersizlikleri, kamera ve ses aygıtlarını açmamaları ve yaşadıkları teknik sorunlar gösterilmiştir. Özgül, Ceran ve Yıldız (2020), uzaktan eğitimle yapılan Türkçe dersinde de öğretmenlerin öğrenci katılımlarını olumsuz yönde değerlendirdiklerini belirtmişlerdir. Türkçe öğretmenleri uzaktan eğitim sürecinde öğrencilerin yaşadıkları katılım sorununu; iletişimsizlik, internete ulaşamama ve isteksizlik ile açıklamışlardır.

Uzaktan yabancllara Türkçe öğretiminde öğrencilerin derse katılımlarının olumlu yönde değiştiğini belirten görüşler de yer almıştır. Ancak bu durumun kamera açma zorunluluğu getirilen kurslarda ortaya çıtığı ve bazı kapalı toplumlarda sosyal çevrede çekingen davranan kız öğrencilerin kendilerini uzaktan eğitimde daha rahat hissetmelerine bağlı olarak ortaya çıtığı belirtilmiştir. Benzer şekilde Bayram, Peker, Aka ve Vural (2019), kadın üniversite öğrencilerinin uzaktan eğitimi erkek öğrencilere göre daha fazla avantajlı olduğu yönünde düşündüklerini tespit etmiştir.

Bazı görüşlerde $(n=4, \% 8,16)$ ise uzaktan yabancılara Türkçe öğretiminde öğrencilerin derse katılımlarının yüz yüze eğitime nazaran fark yaratmadığı belirtilmiştir. Bunun nedeni ise öğrencilerin odaklanmalarına, aktif olmalarına ve uzaktan eğitim döneminden önce öğretmen ve öğrencilerin birbirlerini tanımalarına bağlanmıştır.

Araştırmada, uzaktan yabancılara Türkçe öğretiminde öğrencilerin en çok yazma $(n=26, \%=44,07)$ ve konuşma $(n=26, \%=44,07)$ becerilerine dönük etkinliklerde zorlandıkları belirlenmiştir. Bu süreçte öğrencilerin yazma motivasyonlarının düştüğü, bir yazma etkinliğini devam ettirmede zorlandıkları, yazma çalışmalarının Word dosyasına geçirmekte, e-posta yoluyla öğretmenlerine gönderme gibi işlerde ve klavye kullanmada zorlandıkları belirtilmiştir. Öğreticilerin yazılı ödevleri anında kontrol etme, düzeltme ve dönüş yapmadaki eksiklikleri öğrencilerin yazma becerisine dönük etkinliklerde zorlanmalarına neden olan diğer bir etmen olarak tespit edilmiştir. Araştırmada, pratik yapacak doğal bir ortamın bulunmaması, etkileşimin azalması, konuşmaya isteksiz davranılması, internet bağlantısında ve seste meydana gelen kopukluklar nedeniyle öğrencilerin konuşma becerilerine dönük etkinliklerde zorlandıkları tespit edilmiştir. Güngör, Çangal ve Demir (2020) uzaktan eğitimin konuşma becerisini olumsuz yönde etkilediğine dair bulgular elde etmişlerdir. Yurdakul ve Duman (2021) ise öğreticilerin uzaktan yabancllara Türkçe öğretiminde konuşma ve yazma becerilerinin geliştirilmesinde güçlük çektiklerine dair görüş belirttiklerini ifade etmişlerdir.

Uzaktan yabancllara Türkçe öğretiminde öğreticilerin $(n=41, \% 97,62)$ en çok temel dil düzeyindeki öğrencilerle dersin işlenişinde zorluk yaşadıkları belirlenmiştir. Yüz yüze eğitimde öğreticilerin ses, görüntü ve beden dilini kullanarak çok basit bir şekilde açıklayabildikleri durumların uzaktan eğitim koşullarında öğretiminin zorlaştı̆̆ı, öğrencilerin bireysel-kültürel art alan bilgileri hakkında öğreticilerin fikir sahip olamadıkları böylece temel dil seviyesindeki öğrencilerle dersin işlenişinin zorlaştı̆̆ belirlenmiştir.

Araştırmada, uzaktan yabancılara Türkçe öğretiminde öğrencilerin Türkçe öğrenme motivasyonlarının düştüğü $(n=29, \% 72,50)$, öğrencilerin Türkçe öğrenme motivasyonlarının arttığı $(n=6, \% 15)$ ve

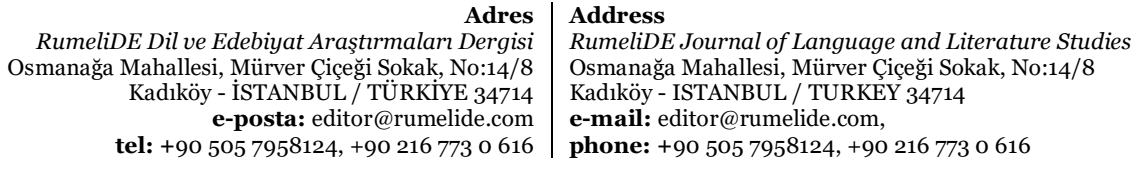


öğrencilerin Türkçe öğrenme motivasyonlarında değişiklik olmadığı $(n=5, \% 12,50)$ belirtilmiştir. Uzaktan yabancılara Türkçe öğretiminde öğrencilerin Türkçe öğrenme motivasyonlarının düştüğünü belirten öğreticiler, bunun, öğrencilerin yaşadıkları internet sorunları, yüz yüze eğitimi tercih etmeleri, kültürel etkinliklere katılamamaları, öğretmenleri ile olan iletişimin azalması, Türkçe öğrenmenin zor bir dil olduğuna inanmaları ve pratik yapma imkânlarının olmamasından kaynaklı ortaya çıtığını belirtmişlerdir.

Öğrencilerin Türkçe öğrenme motivasyonlarının arttığını düşünen öğreticiler, bunu, öğrencilerdeki dil öğrenme kaygısının onları çalışmaya itmesine, ders kayıtlarını tekrar izleyebilme imkânına sahip olmalarına ve mesafeden dolayı yüz yüze eğitimde zorluk yaşayan öğrencilerin uzaktan eğitimde kolaylık yaşamalarına bağlamışlardır. Uzaktan eğitim sürecinde öğrencilerin Türkçe öğrenme motivasyonlarında herhangi bir değişiklik gözlemlemediklerini düşünen öğreticiler, bilinçli ve özerk öğrencilerin her şartta hedefe yönelik davrandıklarını belirtmişlerdir.

Araştırmada, uzaktan yabancılara Türkçe öğretiminde öğrencilerin Türkçe öğrenme motivasyonlarını artırmak için öğreticilerin çeşitli etkinlikler yaptıkları belirlenmiştir. Hedef dilde film/video/şarkı dinletme $(n=14, \% 20)$, sohbet etme $(n=8,11,42)$, anında veya en kısa sürede dönüt verme $(n=5, \% 7,14)$, ödev verme $(\mathrm{n}=4, \% 5,63)$, sınıf dışı etkinlikler yapma $(\mathrm{n}=4, \% 5,63)$, eğlenceli ders etkinlikleri tasarlama $(n=4, \% 5,63)$, gelecekle ilgili beklentide bulunma $(n=3, \% 4,23)$, pozitif yaklaşım sergileme $(n=3, \% 4,23)$, öğrencilerle bireysel olarak ilgilenme $(\mathrm{n}=3, \% 4,23)$, öğrencileri mezun veya daha ileri seviyedeki öğrencilerle tanıştırma $(\mathrm{n}=3, \% 4,23)$, öğrenmeye teşvik etme $(\mathrm{n}=3, \% 4,23)$, kültürel örnekler gösterme $(\mathrm{n}=3, \% 4,23)$, öğrencileri telkin etme $(\mathrm{n}=3, \% 4,23)$, öğrencilere dil öğrenme amaçlarını hatırlatma $(\mathrm{n}=2$, \%2,82), öğrencilerin başarılarını/gelişimlerini bildirme $(\mathrm{n}=2, \% 2,82)$, derste öğrencilerin ilgi alanlarından örnekler verme $(n=2, \% 2,82)$, derslerde öğrenci seviyesini dikkate alma $(n=2, \% 2,82)$ öğrencilerin Türkçe öğrenme motivasyonlarını artırmak için öğreticilerin yaptıkları etkinlikler olarak tespit edilmiştir.

Araştırmada, öğreticiler, uzaktan yabancılara Türkçe öğretiminde öğrencilerin çeşitli sorunlarla karşılaştı̆̆ını ifade etmişlerdir. Bunlar; internet bağlantısında yaşanan sorunlar $(n=40, \% 47,61)$, teknik donanım yetersizliğinden kaynaklanan sorunlar $(\mathrm{n}=10, \% 11,90)$, dijital okuryazarlık yetersizliğinden kaynaklanan sorunlar $(n=8, \% 9,52)$, sisteme alışma sorunları $(n=4, \% 4,76)$, bilgisayar kullanmamaktan kaynaklanan sorunlar $(\mathrm{n}=3, \% 3,57)$, özerk öğrenme becerilerinin yetersizliğinden kaynaklanan sorunlar $(\mathrm{n}=3, \% 3,57)$, klavye kullanamamaktan kaynaklanan sorunlar $(\mathrm{n}=3, \% 3,57)$, ekran yorgunluğundan kaynaklanan sorunlar $(\mathrm{n}=3, \% 3,57)$, ev ya da yurt ortamının uygun olmamasından kaynaklanan sorunlar $(\mathrm{n}=2, \% 2,38)$, internetin pahalılığından kaynaklanan sorunlar $(\mathrm{n}=2, \% 2,38)$, saat farkından kaynaklanan sorunlar $(\mathrm{n}=2, \% 2,38)$, dilin kültürel ortamının uzaklığından kaynaklanan sorunlar $(\mathrm{n}=1$, \%1,19), zaman yönetiminin yetersizliğinden kaynaklanan sorunlar $(\mathrm{n}=1, \% 1,19)$, elektrik kesintisinden kaynaklanan sorunlar, uzaktan eğitime yönelik negatif bakış açısından kaynaklanan sorunlar ( $\mathrm{n}=1$, \%1,19) şeklinde sıralanmıştır. Benzer olarak Karatepe, Küçükgençay ve Peker (2020), uzaktan eğitimde öğretmen adaylarının da çoğunluğunun cep telefonu ile derslere katıldığını belirtmişlerdir. Genel olarak öğretmen adaylarının senkron derslere karşı olumsuz tutum içinde oldukları, gelecekte çevrim içi uzaktan eğitim verme konusunda isteksiz oldukları, kendilerini yeterli görmedikleri ve çevrim içi derslerin eğitimin geleceği olduğuna inanmadıklarını tespit etmişlerdir.

Araştırmada, uzaktan yabancılara Türkçe öğretiminde yapılan kur sınavlarında çeşitli sorunlarla karşılaşıldığı belirlenmiştir. Bunlar; etik sorunlar ( $\mathrm{n}=23, \% 28,75)$, internet bağlantısından kaynaklanan sorunlar $(\mathrm{n}=23, \% 28,75)$, teknolojik yetersizliklerden kaynaklanan sorunlar $(\mathrm{n}=10, \% 12,50)$,

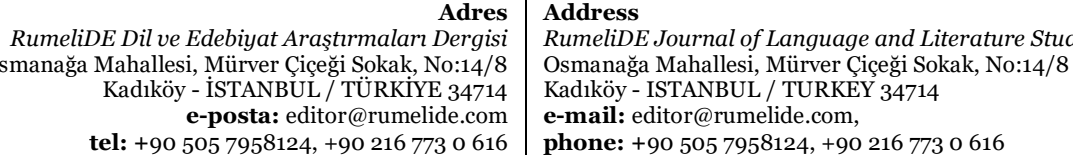


öğrencilerin sınav sistemini anlamamasından kaynaklı sorunlar ( $\mathrm{n}=9, \% 11,25)$, sinav sisteminden kaynaklanan sorunlar ( $n=5, \% 6,25)$, sınavin geçerliğinden kaynaklanan sorunlar $(n=3, \% 3,75)$, klavye kullanamamaktan kaynaklanan sorunlar, öğrencilerin sınava katılmamasından kaynaklanan sorunlar ( $\mathrm{n}=1, \% 1,25)$, öğrencilerin kaygı durumundan kaynaklanan sorunlar $(\mathrm{n}=1, \% 1,25)$, gözlem yetersizliğinden kaynaklanan sorunlar ( $\mathrm{n}=1, \% 1,25)$, sınav süresinin uzamasından kaynaklanan sorunlar $(\mathrm{n}=1, \% 1,25)$, elektrik kesintisinden kaynaklanan sorunlar $(\mathrm{n}=1, \% 1,25)$ şeklinde siralanmıştır. Benzer olarak Avcı ve Akdeniz (2021) de uzaktan eğitim sürecinde öğretmenlerin yoğun olarak teknolojik alt yapı ve internet konusunda sorunlar yasadıklarını tespit etmişlerdir.

Araştırmada, öğreticilerin, ölçme ve değerlendirmede soru-cevap yöntemini (n=21, \%17,65), çoktan seçmeli $(n=23, \% 19,33)$, boşluk doldurmalı $(n=19, \% 15,97)$ ve doğru-yanlış test maddelerini kullandıkları tespit edilmiştir. Bunun yanı sıra öğreticilerin; ödevler ( $\mathrm{n}=9, \% 7,56)$, deneme sınavları $(n=8, \% 6,72)$, açı uçlu sorular $(n=8, \% 6,72)$, yazılı ürün değerlendirme $(n=6, \% 5,04)$, eşleştirme maddeleri $(n=3, \% 2,52)$, kontrol listeleri ( $n=3, \% 2,52)$, dikte yöntemi, kısa cevaplı sorular $(n=1, \% 0,84)$, bulmacalar $(\mathrm{n}=1, \% \mathrm{o}, 84)$, öğrenci ürün dosyası $(\mathrm{n}=1, \% \mathrm{0}, 84)$ ve süreç odaklı değerlendirme tekniklerini $(\mathrm{n}=1, \% 0,84)$ kullandıkları tespit edilmiştir. Benzer olarak Özgül, Ceran ve Yıldız (2020), uzaktan eğitimde Türkçe öğretmenlerinin ölçme ve değerlendirmede ödevleri, hazır testleri ve soru-cevap yöntemini kullandıklarını tespit etmişlerdir.

Araştırmada, öğreticiler, uzaktan yabancılara Türkçe öğretiminin ekonomik açıdan avantajlı olduğunu $(\mathrm{n}=47, \% 51,65)$ belirtmiştir. Bu avantajların mekân $(\mathrm{n}=22, \%=46,8)$, para $(\mathrm{n}=11, \%=23,4)$, zaman $(\mathrm{n}=7$, $\%=14,89)$ ve mesafe $(n=7, \%=14,89)$ açısından işlendiği görülmüştür. Uzaktan yabancllara Türkçe öğretiminin avantajları arasında katılımcıların 9'u $(\% 9,89)$ bilgiye erişimin kolay olduğunu, 6'sı $(\% 6,59)$ dersin tekrar izlendiğini, 5’i $(\% 5,49)$ çeşitli materyal oluşturulduğunu, 4’ü $(\% 4,40)$ konforlu olduğunu, 4’ü $(\% 4,40)$ ulaşllır olduğunu, 3’ü $(\% 3,30)$ teknolojiden yararlanma bilincinin yerleştiğini, 3’ü (\%3,30) zaman esnekliği sağlandı̆̆ını, 2'si $(\% 2,20)$ ödev kontrolü ve dönütlerin kolaylaştığını, 1’i $(\% 1,10)$ Öğrencinin kolaylıkla sertifika aldığını belirtmiştir. Katılımcıların 7'si $(\% 7,69)$ ise uzaktan yabancılara Türkçe öğretiminin herhangi bir avantajının olmadığını belirtmiştir. Benzer bir şekilde Güngör, Çangal ve Demir (2020), uzaktan yabancı dil olarak Türkçe öğrenenlerin uzaktan eğitimin avantajlarına yönelik ders almayı sağlaması, zamanı verimli kullanmayı sağlaması, erişim kolaylığı sağlaması, sosyal mesafeye uygunluk taşıması ve olumlu bir yönünün olmaması şeklinde görüş belirttiklerini ifade ederken öğreticilerin zaman ve mekân sınırını kaldırması, öğretim devamlılı̆̆ını sağlaması ve materyal kullanımı açısından geniş imkânlar sunması gibi olumlu görüşler belirttiklerini ifade etmişlerdir.

Araştırmada, öğreticilerin kendilerini olumsuz $(n=46, \% 56,79)$ ve olumlu ( $n=35, \% 31,42)$ yönde değerlendirdikleri belirlenmiştir. Uzaktan yabancllara Türkçe öğretiminde kendilerini olumsuz yönde değerlendiren öğreticilerden 19'u (\%41,30) yüz yüze eğitimdeki kadar verimli olamayan, 11’i (\%23,91) hareketleri kısıtlanmış, 7'si $(\% 15,21)$ yorulan, 3’ü $(\% 6,52)$ motivasyonu düşük, 2'si $(\% 4,34)$ fiziksel rahatsızlıklar yaşamaya başlayan, 2'si $(\% 4,34)$ yeterli dönüt veremeyen, 1’i $(\% 2,17)$ bilgisayar karşısında ders anlatmaktan sıkılan, 1’i $(\% 2,17)$ yüz yüze eğitimi özleyen biri olarak kendilerini değerlendirmiştir.

Araştırmada, uzaktan yabancılara Türkçe öğretiminde kendilerini olumlu yönde değerlendiren öğreticilerden 11’i (\%41,30) eksik yönlerini görme ve geliştirme imkânı bulan, 8’i (\%22,85) yeterli, 7'si (\%20) özverili, 4'ü $(\% 11,42)$ eğitim teknolojilerini iyi kullanan, 3’ü $(\% 8,57)$ uzaktan eğitime olumlu yaklaşmaya başlayan, 1’i $(\% 2,85)$ yeterli dönüt verebilen, 1’i $(\% 2,85)$ uzaktan eğitimden keyif alan biri olarak kendilerini değerlendirmiştir.

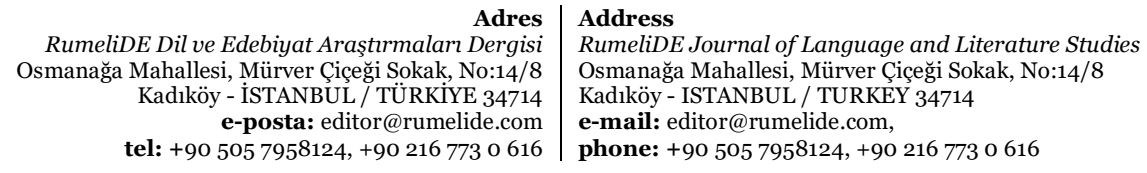


Araştırmada elde edilen sonuçlara dayanarak alanyazına şu önerilerde bulunulabilir:

- Bilişim teknolojisi uzmanlarının, Türkçe öğreticilerinin ve Türkçe öğretim merkezi yöneticilerinin katılımıyla, uzaktan yabancılara Türkçe öğretiminde tespit edilen sorunların çözümüne odaklanılacak çalıştay(lar) düzenlenebilir.

- Uzaktan yabancılara Türkçe öğretiminde öğreticilerin oluşturdukları etkinlik ve uygulamalar ortak bir platformda paylaşılarak deneyim aktarımı sağlanabilir.

- Uzaktan yabancılara Türkçe öğretimi sürecinde kullanılan öğrenme nesnelerinin sonradan da kullanımına dönük nesne ambarları oluşturulabilir.

- Uzaktan yabancılara Türkçe öğretiminde öğrenci motivasyonlarını artırıcı teşvik uygulamaları gerçekleştirilebilir.

- Yurt içinde ve yurt dışında uzaktan Türkçe öğrenenler arasındaki etkileşimi artırıcı sosyal medya platformları oluşturulabilir.

\section{Kaynaklar}

Avcı, F., \& Akdeniz, E. C. (2021). Koronavirüs (Covid-19) salgını ve uzaktan eğitim sürecinde karşılaşılan sorunlar konusunda öğretmenlerin değerlendirmeleri. Uluslararası Sosyal Bilimler ve Ĕ̆itim Dergisi, 3(4), 117-154.

Baltacı, A. (2019). Nitel araştırma süreci: Nitel bir araştırma nasıl yapılır?. Ahi Evran Üniversitesi Sosyal Bilimler Enstitüsü Dergisi, 5(2), 368-388.

Bayram, M., Peker, A. T., Aka, S. T., \& Vural, M. (2019). Üniversite öğrencilerinin uzaktan eğitim dersine karşı tutumlarının incelenmesi. Gaziantep Üniversitesi Spor Bilimleri Dergisi, 4(3), 330-345.

Caladine, R. (2008). Enhancing e-learning with media-rich content and interactions. Hershey, PA: IGI Global. doi:http://dx.doi.org/10.4018/978-1-59904-732-4.

Biriş̧̧i, S. (2013). Video konferans tabanlı uzaktan eğitime ilişkin öğrenci tutumları ve görüşleri. Journal of Instructional Technologies and Teacher Education, 2(1), 24-40.

Duman, G. B., \& Yurdakul, Y. (2021). Türkçenin yabancı dil olarak uzaktan öğretimde öğreticilerin materyal kullanımı ve teknolojik alt yapıya yönelik tutum ve görüssleri. Journal of World of Turks/Zeitschrift für die Welt der Türken, 13(1), 419-438.

Eraslan, F., \& Yücel, D. (2021). Ortaöğretim öğrencilerinin uzaktan yabancllara Türkçe öğretimine bakışı (Kazakistan ve Bosna-Hersek örnekleri). Kesit Akademi Dergisi, 7(26), 483-499.

Erturgut, R. (2008). İnternet temelli uzaktan eğitimin örgütsel, sosyal, pedagojik ve teknolojik bileşenleri. Bilişim Teknolojileri Dergisi, 1(2), 79-85.

Güngör, H., Çangal, Ö., \& Demir, T. (2020). Türkçenin yabancı dil olarak uzaktan öğretimine ilişkin öğrenici ve öğretici görüşleri. Gazi Üniversitesi Gazi Ĕ̆itim Fakültesi Dergisi, 4O(3), 1163-1191.

İskender, M. E. (2021). Yabancı dil olarak Türkçe öğretiminde uzaktan eğitim derslerine ilişkin deneyimler. RumeliDE Dil ve Edebiyat Araşttrmaları Dergisi, (22), 96-117.

Karatepe, F., Küçükgençay, N., \& Peker, B. (2020). Öğretmen adayları senkron uzaktan eğitime nasıl bakıyor? Bir anket çalışması. Journal of Social and Humanities Sciences Research, 7(53), 12621274.

Kaya, F. B., Kahraman, F., \& Uysal, G. (2021). Yabancı dil olarak Türkçe öğretiminde kullanılan ders kitaplarının uzaktan öğretime uygunluğu: Yeni İstanbul örneği. Electronic Turkish Studies, 16(1), 63-84.

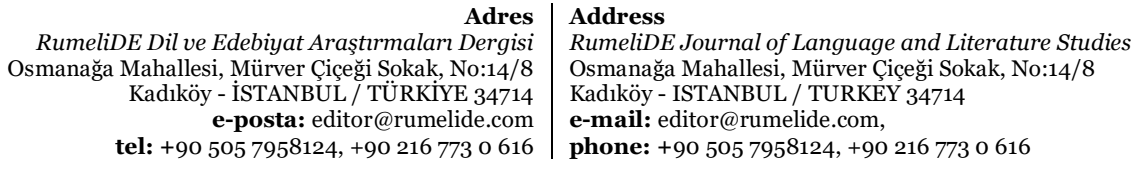


Kaya, Z. (2002). Uzaktan eğitim. (1. Baskı). Ankara: Pegem A.

Kuzu, A. (2017). Çoklu ortam uygulamalarının kuramsal temelleri. İçinde Ö. Ö. Dursun ve H. F. Odabaşı (Ed.), Çoklu ortam tasarımı. (2-33). (3. Baskı). Ankara: Pegem Akademi.

Moore, M. G., \& Kearsley, G. (1996). Distance education: a systems view. Belmont, CA: Wadsworth.

Nipper, S. (1989). Third generation distance learning and computer conferencing. In R. Mason \& A. Kaye (Eds.), Mindweave: Communication, computers and distance. (pp. 63-73). Oxford, UK: Pergamon.

Özgül, E., Ceran, D., \& Yıldız, D. (2020). Uzaktan eğitimle yapılan Türkçe dersinin öğretmen görüşlerine göre değerlendirilmesi. Millı Ĕ̆itim Dergisi, 49(1), 395-412.

Taylor, J. C. (2001, April). Fifth generation distance education. Keynote address delivered at the ICDE 20th World Conference, Dusseldorf, Germany, April 1-5. Retrieved September 8, 2002, http://www.usq.edu.au/users/taylorj/conferences.html

Taylor, J. C. (1995). Distance education technologies: The fourth generation. Australasian Journal of Educational Technology, 11(2), 1-7.

Tekdal, D. (2020). Sosyal bilimler eğitiminde uzaktan eğitimin ortaya çıkış gereksinimi ve tarihçesi. İçinde E. Koçoğlu (Ed.), Sosyal bilimlere uzaktan eğitimde baksş. (25-65). (1. Baskı). Ankara: Pegem Akademi.

Uşun, S. (2006). Uzaktan eğitim. (1. Baskı). Ankara: Nobel Yayın Dağıtım.

Verduin, J. R., \& Clark, J. T. A. (1994). Uzaktan eğitim: Etkin uygulama esasları (çeviren: I. Maviş). (1. Baskı). Anadolu Üniversitesi.

Yurdakul, Y., \& Duman, G. B. (2021). Uzaktan eğitimle Türkçenin yabancı dil olarak öğretimi sürecinde temel becerilerin gerçekleştirilebilme durumunun öğretici görüşleri üzerinden değerlendirilmesi. RumeliDE Dil ve Edebiyat Araştırmaları Dergisi, (23), 167-186.

RumeliDE Dil ve Edebiyat Araşturmaları Dergisi Osmanağa Mahallesi, Mürver Çiçeği Sokak, No:14/8 Kadıköy - İSTANBUL / TÜRKIYE 34714 e-posta: editor@rumelide.com tel: +90 $5057958124,+902167730616$
Address

RumeliDE Journal of Language and Literature Studies Osmanağa Mahallesi, Mürver Çiçeği Sokak, No:14/8

Kadıköy - ISTANBUL / TURKEY 34714

e-mail: editor@rumelide.com,

phone: +90 505 7958124, +90 2167730616 